10559193

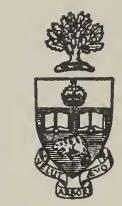

Library

of the

University of Toronto 


$$
5 /-
$$




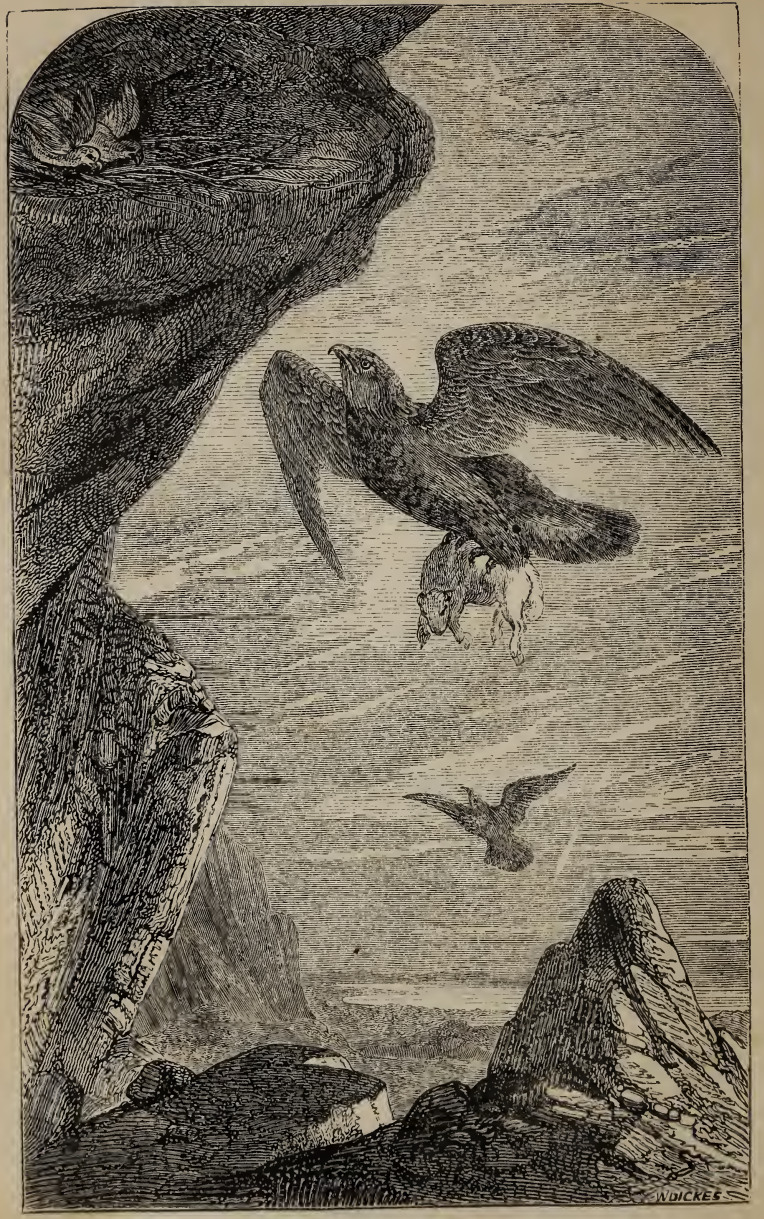

THE EAGLE. 


\section{BRITISH BIRDS.}

\section{THE LAND BIRDS.}

"Natural History is just anither name for Natural Theology-and the sang $o$ ' the laverock, and the plumage ' $o$ ' the goldfinch-do they not alike remind us o' God?"

Professor Wilson.

L O N D O N :

THE RELIGIOUS TRACT SOCIETY;

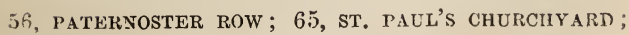

AND 164, PICCADILLY :

AND SOLD BY ALL BOOKSELLERS. 
I(INDON : PRINTED BY W. CLOWES ANI) SONS, STAMFORD STREET. 


\section{PREFA CE.}

I BELIEve it is not often that young persons trouble themselves to read the preface of any book which is put into their hands. I hope, however, the readers of this little work will give an attentive perusal to its preface, since it will be found to contain useful information which would not be so suitably given elsewhere.

Probably you may expect, in a book on British birds, that mention should be made of those you see in the farm-yard, such as the turkey, the peacock, the common fowl, and others. Now, these birds, which are what we call "domestic fowls," are not natives of our country, nor voluntary sojourners here, living in a state of nature, and providing for their own sustenance. They are foreigners, dependent on man for their daily 
supply, and in subjection to him. They therefore have no place in a history of British birds, and it is only by a sort of permitted license that they are found introduced into such works. Lest, however, any should be disappointed and at a loss in not finding them noticed in this work, a short account of them shall be given here.

The Domestic Fowl is of Indian origin. Our original breed has multiplied into numerous varieties, and great, indeed, is the extent to which the passion for rearing them has been carried, as has been seen in the exhibitions of the Cochin-China and other breeds. At what period, or how, the fowl was introduced into the British isles, it is now impossible to ascertain; but it must have been very early, since it was among the things forbidden by the Druids as food.

These household birds seem, like the faithful dog, especially intended for the service of man, as, with the exception of North and South America and the great Australian continent, there is scarcely any portion of the globe where poultry have not been known and cherished from a very remote period. 
The origin of our TURKEY is the wild bird of Mexico. It was domesticated by the Indians, before the discovery of America, and brought to Europe by the Spaniards. These birds are now so extensively spread, that in some parts of the continent they have nearly returned to their original wild state. In their native wilds of North America, they herd together in large flocks, but are becoming more scarce, being driven from their accustomed haunts by the settlers, who have taken possession of their land. The following account of them is given by a traveller in that country. "I was awakened in the morning early by the cheering converse of the wild turkey-cocks, saluting each other from the sun-brightened tops of the lofty cypress and magnolia. They begin at early dawn, and continue till sunrise. The high forests ring with the noise of these social sentinels, the watchword being caught and repeated from one to another for hundreds of miles around, insomuch that the whole country is, for an hour or more, in a universal shout."

Tame turkeys, like all. animals in a state of domestication, are of various colours; but it is needless to speak of a bird known to every one. 
The greatest weight they can be made to attain is thirty pounds; those great birds which are sent to the London markets about Christmas, principally from Norfolk, frequently weighing from twenty to twenty-five pounds.

The common Guinea fowl, or Pintado, is too well known to require any description. This species, now so common, was originally brought from Africa; from whence it has been dispersed over every part of Europe, the West Indies, and America. It is kept in a domestic state almost everywhere, but is not so tame as the turkey, and it submits to restraint with difficulty.

THE PEACOCKs are among the most gorgeous and beautiful of the feathered race, and have been admired in all ages. The species long naturalized in Europe forms the most striking ornament of our poultry yards and aviaries. It is a native of India, where, in some districts, it is very abundant. The manners of this superb bird, in a state of domestication, are familiar to all; but, perhaps, it is not generally known that, while in common with all our domestic poultry, it eats worms, insects, larvæ, and the like, the pea-fowl is a decided enemy to snakes and lizards, which it 
eagerly devours. The first notice taken of these birds, is to be found in the Bible, (2 Chron. ix. 21,) where we are told that they made part of the cargoes of the rich and valuable fleet which every three years imported the treasures of the east to Solomon's court.

Our domestic GEESE are descended from the Marsh or Fen goose, which is a species more easily tamed than some others, particularly if taken young. How many benefits we derive from it, in various ways, we all know, and many particulars respecting this bird in its domesticated state are given in that part of the volume on British Water Birds which refers to the wild species.

Our common tame Duck also owes its origin to the wild species called the Mallard, but has long been domesticated; and has lost in the process the quick, keen, sprightly look and shape, which distinguish the wild bird. It is said that the Chinese, of all people in the world, are the most skilful in the management of poultry, particularly of ducks; and there seems little doubt that, by proper management, much improvement might be made in this, as well as in others of our domestic birds. 
Having thus introduced, in few words, the feathered inhabitants of the farm-yard to the rearler's notice, I will add a few observations which I much hope will be read and remembered. In the study of the natural history of birds, which this book is meant to assist you in commencing, you will find, if you enter on it aright, a source of high delight, and lively interest and instruction. Birds are, perhaps, the most purely pleasure-inspiring of all the living-creatures we see around us. They are full of attraction, when we consider the elegance of their form, the beauty of their colours, the variety and grace of their movements, and the sweet melody of song with which they charm our ears; and you may always enjoy the pleasure they afford, since, go where you will, be the place and season what they may, there is always a bird to be found, which, attentively considered, will afford you instruction and pleasure. All creation claims our attention, and amply rewards our research; and perhaps it is not too much to say, that the study of birds is not only one of the best and most certain sources of rational enjoyment, but that it is one which leads, more directly than most others, to the love, and consequently to the study and 
knowledge, of all the wide kingdom of nature and of nature's Divine Author.

Happy the young naturalist who early takes delight in studying that fair book which, on every side, sweetly invites him to learn by its instructions to look upward to the great God and Father of all. Then only will he know the true uses, and enjoy the highest delights, of these wondrous and beautiful works when he "searches them out," and "takes pleasure therein," as the handiworks of his God and Saviour, while with a humble and loving spirit he offers praise to him from a heart renewed by God's grace, and consecrated to his service. To such a one-

"Nature with open volume stands

To spread her Maker's praise abroad;

And every labour of his hands

Shows something wortliy of a God."

And nature leads us, when we have deeply read its lessons, and prayerfully studied its mysteries, to feel that " the whole creation" stands in need of a Redeemer who shall rescue both man and beast from those dire results of sin, beneath which they groan and travail in pain together until now.*

* Rom. viii. 22. 
In taking leave of my reader, I would fain impress upon his heart the thought that he cannot truly enjoy and understand the works of God until, reconciled to him, he has, through faith in Christ, obtained the pardon of sin and "the renewing of the Holy Ghost," who alone can purify his mind from its natural darkness and selfishness, and inspire it with sincere love and generous sympathy for every living creature. An unloving, a selfish, and a complaining spirit stands as a barrier between us and the pure delights afforded by the works of nature; but a Christian, loving, devout soul is in harmony with the will of God, and rejoices in his works, because they speak his praises and show forth his glory. 


\section{INTRODUCTORY CHAPTER.}

THE object of this work being to furnish the young reader with some general facts of interest with reference to our own native birds of various classes, it is not intended to speak on the subject of ornithology in general, but to confine ourselves strictly to the feathered inhabitants of our islands. There are many pleasing and instructive works on ornithology which treat on the formation and habits of birds, and this part of the study is full of interest, and affords scope for much delightful anecdote, illustrative of the instincts and manners of birds.

"The language and the ways" of the various living creatures with which the earth and the air are replenished must always be of chief interest to those who lovingly and rationally study them. Accordingly, those anecdotes which illustrate the various faculties and passions of animals form the chief attraction of books on natural history, at all 
events to the general and unscientific reader. And if it be true (as Milton assures us it is) that animals " know and reason not contemptibly," how much must the observation of such powers increase our estimate of the value of animal life ; and how carefully should we preserve all the proofs and instances that fall within our notice, of such capabilities in the brute creation! Those who do so, assist in the good work of awakening a due regard and kindly feeling for the lower animals, and of obtaining for them the protection and consideration they so justly merit. Although it be beyond the province of the present book to go at length into this subject. yet a few words on it may be permitted, seeing that our British birds share, with their congeners of other lands, the traits and habits of which we speak; and our young readers may be induced, by having their attention turned to such an attractive department of the subject, to pursue with more interest the study of ornithology in general.

There are few persons who have it not in their power occasionally to remark the habits of birds, and they who do so will soon find that it is a mistake to impute their peculiarities to instinct alone. There is much carelessness in our usual manner of observing the habits of the animal world; and we lose much by disregarding and 
neglecting the impulses of the creatures which contribute so much, in various ways, to our comfort and enjoyment. Who can doubt, if he carefully watch the habits of our familiar birds, that they give unmistakable evidence of being actuated by the passions of love, fear, sympathy, joy, emulation, and so on? The most powerful of these is, undoubtedly, love, especially in the form of parental affection. It is well known that the attachment of birds to their PARENTAL young is not exceeded by that of any other creatures. The boldness and sagacity continually manifested by them in the protection and defence of their broods is truly surprising, especially when the natural timidity and defencelessness of most of the species is considered. During the breeding season their whole existence is absorbed in their duties, and their whole natures undergo a change. Examples of the devoted attachment of the parent birds to their young are so common as to excite no surprise, scarcely, indeed, to awaken interest. And yet, what can be more touching?

It is but a short time since an instance of the kind occurred under my notice. Walking in the neighbourhood of a populous city, I was accosted by a couple of grinning urchins, who presented to me a nest containing three callow fledglings, which 
they offered for sale. On inquiry it came out that they had stolen the nest from a hedgerow. "The young birds will die without the mother," said I. "Oh! we ha' got her too; she wouldn't leave 'em; so we put her in a cage at home!" Alas! poor bird; another victim to maternal love, exercised at the cost of freedom; dearer to her than life itself! Probably her fate was similar to that of the blackbird, whose nest was stolen by a boy from the Great Park of Windsor, and carried by him, with the young brood it contained, to his house, where he placed it in a cage outside his chamber window. The parent birds were witnesses to the theft, and followed their captive young ones, which they afterwards fed daily until they were fledged. 'The boy then sold them, one by one, as opportunity afforded, till they were all disposed of. The morning after the last bird was sold, the female blackbird was found dead beneath the cage in which her beloved offspring had been confined.

It has been remarked by an accurate observer, that the natural timidity of birds is a PEAR, great preservative to them. The female of almost all birds is invariably silent, or, at least, monotonous. If she were disposed to sing during the period of incubation, or while rearing the young, her place of retreat would be more readily 
discovered. When disturbed she quits the nest in the most silent and quiet manner possible; no sound or rustle betrays her movements, nor does she utter a cry of alarm or surprise. When she does give an alarm it is to warn the young brood of danger; and the hint is speedily acted upon. They are all dispersed and concealed among the long grass and leaves in a twinkling. If a bird of prey be in sight, it is curious to observe the agitation and excitement manifested by the inmates of the poultry yard. A turkey has been seen to crouch, with her whole brood under her, pinned down to the ground as it were, for an hour together, while their formidable foe has remained hovering overhead. At last, upon his disappearance, the trembling parent, who had continued piteously crying, suddenly changed her note, and sent forth another cry, which immediately restored life to her frightened offspring, and they all emerged from their shelter and flocked around her with expressions of delight.

It is well known that in paroxysms of fear the human hair has, occasionally, turned white almost instantaneously. By whatever process this extraordinary cliange is effected, we are assured by naturalists that it is in full force as regards the feathers of birds; for although not instantaneons in its operation, it has taken place, 
and the result is visible when the moulting season returns. Dr. Young, in speaking of the change of colour in the plumage of birds from fear, says : - "A blackbird had been surprised in its cage by a cat; when it was relieved, it was found lying on its back and quite wet with sweat. The feathers fell off and were renewed, but the new ones were perfectly white. A grey linnet happened to raise its feathers at a man who was drunk. $\mathrm{He}$ instantly tore the creature from its cage, and plucked off all its feathers. The poor animal survived the outrage, and had its feathers replaced, but they were also white."

The sympathy and fellow-feeling shown by SYMPATHY birds is another very striking and pleasing AND
FELLOWFEELING. highly characteristic of benevolence and kindness of heart in the human race, are most powerfully felt in the animal world," says Mr. E. P. Thompson, in his valuable work on "The Passions of Animals:" - "They are less surprising when extended from one to another by those of the same species, but are particularly so when exercised between those of different habits and orders. There must exist a fellow-feeling, a knowledge of the suffering felt, and a desire to alleviate it-faculties so far exceeding the highest degrees of intelligence ordinarily ascribed 
to the brute creation, that it must be acknowledged they are endowed with powers in which instinct takes no share. A wounded crow left in a field, is soon surrounded by its fellows, seeking to assist it; a swallow entangled in its nest by a bit of thread, was immediately aided by other swallows, which flew violently against the thread, with the view of breaking it."

Birds have been known to feed the young of those whose parents had been destroyed. A gentleman had a young cock thrush brought to him early in the spring. It throve and did well. Some time after a nest of helpless young blackbirds was placed in the cage with the thrush. The latter, as if aware they needed his care, fed and brought them all up.

Dr. Percival, in his "Dissertations," gives a remarkable instance of the sympathy and sagacity of some rooks. He was watching the evolutions of a large colony of these birds which had been established many years in a grove on the banks of the Irwell, near Manchester. As he was thus noticing their various labours and pastimes, a strange accident occurred. A rook, by a sharp and sudden turn, struck his beak against the wing of another. The sufferer instantly fell into the river. A general cry of distress followed, and the birds, with every expression of anxiety, fluttered 
over their distressed cornpanion. Apparently animated by their sympathy, or, perchance, by their language of counsel, known to themselves, he sprang into the air, and by one strong effort, contrived to reach the point of a rock which projected into the river. The joy became loud and universal, but, alas! it was soon changed into notes of lamentation, for the poor wounded bird, while attempting to fly to his nest, dropped again into the river and was drowned, amid the moans of its whole fraternity.

There is a proverb-"As merry as a kitten ;"

JOY AND and who has not watched with pleasure PLYYFUL-
NESS. chase each other and indulge in a thousand frolicsome gambols, on a warm summer's evening? Birds are constantly to be seen engaged in these evolutions, so expressive of joy and delight, that it is impossible to mistake their meaning.

Very curious are the movements of the crane and the trumpeter. The latter (an American bird) stands on one leg, hops about in the most eccentric manner, and throws somersets. The crane expands its wings, runs round in circles, leaps, and throws little stones and pieces of wood into the air, which it endeavours to catch as they fall, or pretends to avoid, as if afraid. Water birds, such as ducks and geese, dive after each 
other, and cleave the surface of the water with outstretched neck and flapping wings, throwing the spray in showers about them.

Birds of the pie kind, which have much of the monkey nature in them, are full of mischief, play, and mimicry. Many stories in point are told of pet birds of this description; tame magpies, especially delight in playing strange tricks. One of them is said to have been seen busily engaged in a garden, gathering pebbles, and with much gravity dropping them into a hole about eighteen inches deep, which had been made to receive a post. After each stone it dropped, the bird cried, currack! in a triumphant note, and immediately set off for another. On examination, a poor toad was found in the hole, which the magpie was stoning for his amusement.*

Much has been said as to the exciting cause of the song of birds, some attributing it to one cause, and some to another. Probably $\begin{gathered}\text { rarou. } \\ \text { mior. }\end{gathered}$ various causes combine to produce so delight ful an expression of the little creature's emotions. Emulation must undoubtedly be regarded as one powerful provocative to song. Caged birds are frequently observed to sing against each other. A very remarkable story is told by Mr. Jesse 
(who vouches for its authenticity) of a gentleman who possessed an American mocking-bird, in such health and vigour, that it was either constantly singing, or else imitating the various sounds it heard. In order to try the powers of this bird its owner purchased a fine sky-lark. When placed in the same room with the mockingbird, its song was heard to echo through the house. The other was silent for some time after the thrilling carol had ceased : at last it burst forth in the strains of the "aërial songster," but louder and clearer, as if mounting, and stretching its wings heavenward. The lark was silent from that moment, nor was it ever heard to utter a joyous note afterwards. Wishing to test the powers of the mocking-bird still further, the gentleman purchased a blacklird, celebrated for its vocal powers. Early on the morning of the second day after it was placed in the room with the mocking-bird, its charming notes were warbled forth with all the sweetness and modulations which may be heard in its native "thorny brakes." The stranger bird listened, and was still for some time; then, all at once he began to give forth the blackbird's notes ; but even sweeter and louder than those of the woodland songster. The poor blackbird heard them, felt that it was conquered, remained silent, drooped, pined, and died. 
The same spirit of rivalry is visible in many of our domestic birds. What object can be more pitiable than the defeated cock? He is the very picture of dejection, as, with drooping tail and draggled feathers, he mopes, or slinks away, to hide his fallen vanity, while his triumphant rival plumes himself, and, with victorious crow, ruffles his plumage, and displays its beauties, strutting proudly, and suiting his actions to the dignity of the moment.

A curious vanity and self-love are evinced by some birds, at sight of their own reflected image. A gentleman had in his possession two brown cranes. After some years one of them died, and the survivor became disconsolate. He was apparently following his companion, when his owner introduced a large looking-glass into the aviary. The bird no sooner saw his reflected image than he placed himself close to the mirror, plumed his feathers, and showed every sign of happiness. The scheme completely answered; the crane recovered his health and spirits, passed almost all his time before the looking-glass, and lived many years afterwards. The goldfinch appears to be a vain bird, for, if a looking-glass is placed before it, the reflection of its own gay feathers seems greatly to delight it.

The sagacity of brutes is one of their most 
remarkable characteristics, and it often appears, in its manifestations, to pass the limit of mere SAGACITY. instinct. In birds, instances of it are not so numerous or so well known, but there are some species which evince no small share of contrivance and skill in action.

It is well observed by Mr. Thompson, that all these faculties and propensities we have noticed in animals become usually more developed in a state of confinement, and consequently of tuition, than in their natural wild condition. Hence the extraordinary sagacity observed in animals more or less under the control and management of man.

Birds, those "free denizens of air," are, necessarily, far less influenced by our actions, and beyond the reach of our training; yet, accurate observers have found them showing an instinctive foresight, caution, and cleverness truly surprising.

Many birds can by no means be induced to touch anything which would be injurious to them. For instance, if flies be given to young ducks, they will greedily devour them; but when bees are placed before them they will look at them, with their little heads on one side, but never touch one.

Two remarkable instances of instinctive sagacity in the crow family are mentioned by one of our 
naturalists. When the cholera broke out with frightful severity at St. Petersburgh, in July, 1848, the crows, which are extremely abundant in that city and settle familiarly in the streets, forsook it, returning as soon as the virulence of the disease had ceased.

In the neighbourhood of Newcastle there was a fine old ash tree which had for many years been the haunt of a colony of rooks, whose nests crowded the branches. In each succeeding year they returned to carry on the business of nesting, till suddenly their numbers diminished, and soon but a few lingerers remained, seemingly loth to quit the favourite spot, commencing their labours for two or three seasoris, but without completing their task; and, finally, these also transferred thernselves to a new locality. The cause of this desertion was revealed shortly afterwards, when the tree, which, unperceived by all, had decayed at the root, fell beneath the violence of a severe gale.

Closely resembling the common bullfinch is the pine grosbeak, (or pine bullfinch as it is frequently called)-an occasional visitor in these islands, which is very abundant in the north of Europe and in America. A friend of M. Audubon writing of this sweet songster says :- "I received a male in full plumage, but so emaciated that it 
seemed little else than a mass of feathers. By cautious feeding however, he soon regained his flesh and became so tame as to eat from my hand without the least appearance of fear. To reconcile him gradually to confinement he was permitted to fly about my bedroom, and upon rising in the morning, the first thing I did was to give him a small quantity of seed. But three mornings in succession I chanced to lie rather later than usual, and each morning $I$ was aroused by the bird fluttering upon my shoulder and calling for his usual allowance. The third morning I allowed him to flutter about me some time before showing any symptom of being awake. He no sooner perceived that his object was effected than he retired to the window and waited patiently till I was dressed." Surely there is more than instinct in such conduct. Have we not in such actions evidence of memory, association, and inference?

An instance of cautious sagacity in a peewit, is mentioned by Brehm. He had placed some horsehair snares over its nest, and the bird having alighted, at the distance of thirty paces, ran to it, and seeing them, pushed them aside with her bill. The next day he set them thickly round the nest; but the bird instead of running, as usual, to it, alighted directly upon it.

Every one knows that rooks will fly at the ap- 
proach of a man with a gun, while they follow the plough so closely, as to be within reach of a long: stick: and they are undoubtedly aware of the immunities brought by the sabbath day; so much so that it is a saying in some parts, "Bold as a rook on Sunday." A gentleman in Wiltshire, who was a strict preserver of his game and fish, had his ponds regularly visited by herons on a Sunday. Not a heron was to be seen near them on any other day.

Some birds in a state of confinement, make a skilful application of their powers in the attempt to liberate themselves, or to remove difficulties. A tame raven, which was coufined by a chain of three feet long, fastened to a ring round its neck, had recourse to this contrivance whenever it flew or hopped about. It always gathered the chain in its bill so as to prevent it from hurting its neck.

These birds, and their congeners, are proverbially clever and sagacious in pilfering and concealment, and their inquisitiveness renders them ever on the alert to make some new discovery; they have also been known to show a remarkable retentiveness of memory. Two magpies, kept in a large kitchen garden, were in the habit of concealing bits of meat and other stores. Some men were one day set to dig up that part of the ground 
which had been the favourite hiding-place of these birds. Scarcely had they commenced operations, when the magpies showed that they were perfectly aware of what was going forward. They hastened to the spot, and with their bills cleared away the earth from their hidden treasures, which they conveyed, one by one, to some distance. In this way seven or eight bones and bits of bread were disinterred, although some of them had been buried three or four weeks; thus indicating that the lirds perfectly recollected peculiar spots.

It is a necessary consequence of the social life LANGUAGE, in animals that they must possess some LANGUAGE,
COMMUNI- means of communication with each other,
CATION. without which the demand for mutual aid would be impracticable. "The language of animals is an intuitive expression of their inward conceptions and wants by signs, looks, or voice." Most animals use particular modifications of sound to communicate their meaning to their young and their companions, and this seems perfectly successful. The various notes of call, of alarm, of impatience, and of joy in the poultry yard are very significant and expressive-unmistakable utterances of the feelings of anger, grief, fear, or pleasure; and a person familiar with the notes of wild birds has no difficulty in distinguishing between the notes of pleasure and alarm. 
A loud outery was heard one day amongst a parcel of sparrows, tomtits, and chaffinches. The noise was not one of pleasure, nor did it resemble their shrill screams when fighting. The bustle occurred close to a window, where no hawk would venture. Nor could a cat be seen anywhere in the neighbourhood. Yet still the din went on, and the bush in which the noisy assemblage had taken refuge shook with the fluttering of wings and clacking of tongues. At last, at the bottom of the bush a little sharp snout was seen protruding, and a pair of inquisitive eyes peered out. It was a weasel, which no sooner saw that it was noticed than it took to its heels; whereupon, in an instant the outcry ceased, and the whole party dispersed.

The loud cries of some birds, particularly of many of the migratory water birds, which fly by night, are evidently intended for the purpose of keeping in company. In the silence of the night a flight of wild geese may be heard incessantly cackling high in the air, on their way to some distant spot. The distance, too, at which the call of some birds may be heard is very extraordinary. How marvellous and beautiful is the instinct which has been implanted in defenceless birds, to make their migrations by night! It affords a remarkable and delightful proof of the care and 
beneficence of God on behalf of these his creatures. If such birds as the quail, the woodcock, the snipe, the nightingale, and the swallow performed those aerrial voyages in the day-time, they would be subject to the harassing attacks of birds of prey, as well as of man, but shaded by the friendly veil of night they pass on in security, proclaiming to each other, by friendly calls, the route to be kept.

But the mode in which birds convey to each other, under certain circumstances, their ideas and wishes, is often quite beyond our observation. That they do carry on a mutual intercourse and communication of ideas is indisputable. A gentleman who held a high official appointment in Persia, related the following anecdote to $\mathrm{Mr}$. Jesse, which is remarkably in point :-

Storks abound in Persia, and make their nests on old towers and ruins. One season a pair of these birds returned to their old haunt on the top of a building opposite one of the windows of this gentleman's residence, but they found it pre-occupied by a pair of pea-fowl. The storks vainly endeavoured to dislodge the intruders; they resolutely refused to give up possession. In this dilemma the storks flew away, but returned in two days, accompanied by a large number of other storks, who assisted effectually in driving 
away the pea-fowl. Having done this, they remained quietly near the spot, to see that their friends were securely reinstated, and having ascertained this to their satisfaction, they left them, and returned whither they had come.

Similar manœuvres may be witnessed among our own household birds, the martins. They build, as all the world knows, under the eaves of houses; and, not unfrequently, when the nest is completed, the sparrows will come and take forcible possession of it. The martins, unable to dislodge the unwelcome intruders, convoke their companions, some of whom keep watch over the captive occupant of the nest, while others bring clay, and completely closing up the entrance of the nest, fly off, leaving the delinquent sparrow to be suffocated or to perish of hunger.

Bishop Stanley has given, in his delightful "Sketches of Birds," a remarkable anecdote illustrative of this strange and unaccountable faculty. The incident is said to have occurred at Ennis, in 1828.-An old goose, which had been for a fortnight hatching in a farmer's kitchen, was suddenly taken violently ill. She soon after left her nest and went to an outhouse where there was a young goose of the first year, which she brought with her into the kitchen. The young one immediately scrambled into the old one's nest, sat, in due time 
hatched, and afterwards brought up the brood. The old goose, as soon as the young one had taken her place, sat down beside the nest, and shortly after died. As the young goose had never been in the habit of entering the kitchen before, the fact can only be accounted for by supposing that the old one had some way of communicating her thoughts and anxieties which the other was perfectly able to understand.

Another remarkable instance of a similar kind we quote from the same author, who says it was seen by a number of persons and communicated by the best authority. A French surgeon, at Smyrna, wishing to procure a stork, and finding great difficulty in doing so on account of the extreme veneration in which they are held by the Turks, stole all the eggs out of a nest and replaced them with those of a hen. In process of time, the young chickens were hatched, to the utter amazement of the storks. The male bird soon after disappeared, and was not seen for two or three days, when he returned accompanied by a host of his companions, who all assembled in the place and formed a circle, taking no notice of the numerous spectators whom so unusual an occurrence had collected. The female stork was brought forward and placed in the midst of the circle, and, after some consultation, the whole flock fell upon her, and tore her to 
pieces; which done, they immediately dispersed and the nest was entirely abandoned. After these instances, which might be multiplied almost at pleasure, our readers will agree with us that there is no need to inquire

\section{“__ If birds confabulate or no."}

Perhaps this Introductory Chapter may be most suitably concluded by a few observations on the social impulse in birds, which I will ${ }_{\text {rmpurss. }}^{\text {socras }}$ endeavour to illustrate by a few anecdotes.

The wisdom and beneficial effects of the law, by which animals are impelled to form themselves into families or larger societies, for mutual benefit and protection, is very evident; and nothing in the wide field of natural history is more remarkable and interesting than the economy of the gregarious animals and the association, in some cases, of thousands of individuals in one republic, occupying one habitation, and combining their labours for the common good. These combinations art chiefly seen in the insect races ; but the social impulse is shared in common by animals generally.

With the exception of birds of prey and a few others, all the feathered tribes seem to have a general tendency towards association into flocks or family parties and pairs. The woodlark does not unite in company, but it associates in its own 
little family groups. The linnet lives and delights in company, frequenting open commons and gorsy fields. Several pairs, without the least rivalry or contention, build their nests, and rear their young, in the same neighbourhood. They form large associations, feeding and moving in company, as one united household. They will pass hours together on the top branches of some sunny tree, enjoying the warmth and chatting with each other in low and gentle notes.

The jay and its family associate during all the autumn and winter months, taking evident delight in each other's company. They separate only to become the founders of new establishments.

Starlings are extremely sociable in their disposition, and when they quit the nest keep together in families for a short time and then join with others, till they form those vast flocks seen in meadows. No birds appear to have so much conversation, if the term may be used, as starlings; especially when they visit their roosting places in the evening. They seem, then, to be congratulating each other with much satisfaction. They are seldom seen alone; to feed, they will associate with the rook, the pigeon, or the daw; but they chiefly roost with their own families. Should any accident separate an individual from its companions, it will sit disconsolate, piping and 
plaining, till some of its associates join it. Even in small parties they keep continually calling with a fine clear tone, and inviting others to join them.

The gregarious propensity of magpies is very observable in open countries. In the inclosed lands of England they are more commonly seen in pairs or families, like the jay and titmouse. A naturalist, residing in Somersetshire, says, "In the winter, magpies assemble to roost in large flocks in a wood near by. Hundreds come there regularly every evening, flying in from all directions. They formerly frequented an orchard on the opposite side of the valley to which the wood is situated; but, having been shot at, they deserted it for the wood. The next evening not one magpie came to the orchard, but all went simultaneously to the wood as if they had previously agreed arnong themselves to do so. In moonlight nights they might be seen clustering together on the trees."

Besides the assemblages that take place at particular seasons in different species, as the goldfinches, larks, starlings, etc., others continue their association without interruption, as the various species of wild fowl. These can hardly be said to separate for the purpose of nidification, since they frequent the same district of marsh or swamp, for that purpose, in the northern regions in immense 
flocks, again taking flight together towards the south as the cold season approaches. The peewits and plovers also constantly remain in flocks or families.*

Few birds are more gregarious than the rooks, which we see at nightfall,

"Retiring from the downs, where all day long They pick their scanty fare; a black'ning train Of loitering rooks thick urge their weary flight, And seek the shelter of the grove."

Their habits, in this respect, are so well known as to need no eomment.

Fieldfares, again, which arrive in this country in great flocks from the northern parts of the continent in the beginning of the autumn, return, in the same manner, to their native forests, where they stud the huge fir-trees with their nests. It woula appear that with them, as with the rooks, the sense of security occasions these associations, as they have evident marks of keeping watch to announce the approach of danger, and there are few birds more difficult to get near to.

The system of setting a watch to give the signa] of danger is adopted generally by all the gregarious races of birds. These sentinels station themselves at some little distance from the main

* Thompson. 
body, usually on an elevated point, and give the alarm by uttering a peculiar cry. Alluding to this habit in wild geese, the poet Schiller says ;-

“When they go forth to graze, with jealous care They place a watch, which, with keen ear intent On coming danger, sounds its shrill note, And warns the ready flock."

It is well known how difficult it is to get within gunshot of a large flock of birds which appear so busily employed in feeding that it might be supposed they could see nothing else. And doubtless they often do see nothing beyond the food of which they are so diligently in search. But in some neighbouring tree a keen look out is kept by one of the party, and the moment his alarum is heard, away goes the whole troop beyond the reach of the disappointed fowler who fancied himself secure, as he lurked in ambush behind some tree or hedgerow near.

This spirit of sociability in birds is not confined strictly to the species, but extends to others of their kind, and even to incongruous animals. Swallows, sparrows, rooks, and other gregarious birds will join together and make common cause in defending their young from predatory birds or animals.

An "out-door naturalist" says, "I have seen a curious instance of birds of very different habits 
and nature, such as a sparrowhawk, jackdaw, green woodpecker, nuthatch, and wren, all building and having either eggs or young ones, at the same time, either on or in the same tree. This happened in an old oak tree, near a place at which I was residing, the heart of which is completely decayed. On the topmost branches a pair of sparrowhawks had made them a nest, which, at the time I examined it, contained four eggrs. In a hollow of the tree near the top was a jackdaw's nest with five young ones. A little lower a woodpecker was hatching five eggs; still lower was a nuthatch's nest containing seven young birds, and near the foot of the tree, in one of the crevices of the bark, which was overgrown with ivy, a pair of wrens had made their domicile, in which were several eggs. These birds seemed to live in perfect harmony, as I watched them frequently."

Mr. Jesse relates the following anecdote of the affection subsisting betw.een two birds. A gentleman in Scotland had a cock pheasant sent him, which he confined in a pen with a solitary chicken. These birds formed a great affection for each other, which they showed in various ways. After a time the pheasant died, and was immediately stuffed, and the chicken was turned loose. It appeared miserable, however, after the death of its companion, and the stuffed bird having been 
shown to it, it drooped its wings, after having attempted to get at it, kept its eyes fixed upon it, and in this attitude died.

Not unfrequently an attachment springs up between birds in a domesticated state and animals with which they are associated. A remarkable instance is related of a goose, which attached her.self so much to a house-dog by whom her life had been accidentally saved, that she constantly kept company with him, forsaking her natural allies, and even placing her eggs in his kennel; and, when he fell ill, refusing to leave him, even to procure food.

A pleasing anecdote is related by Mr. Jesse, about a cat and a jay. The bird had been introduced into one of the wards of a hospital, for the purpose of amusing the patients. One day a cat chanced to go into the ward with a mouse in her mouth. One of the attendants took the mouse from the cat and gave it to the jay, who pecked the fur from it, and then ate it. The next day, to the surprise of every one, pussy brought another mouse into the ward, went up to the jay's cage, and gave it him, and so she continued daily to do for many weeks. At length the poor captive bird died, but, for three days after, the cat came to the cage with a mouse in her mouth.

The social nature in birds is undoubtedly one 
of the most pleasing and attractive traits in their CONFIDENCE characters, and it is that which chiefly IN MAN. attaches them to man, since, when tamed, they distinguish their masters and benefactors with endearing marks of affection and gratitude. Numerous, indeed almost innumerable, instances of this kind are seen in birds of various species, as in parrots, geese, bullfinches, the starling and rook tribes, and others. Nor is this feeling shown only by birds in a state of confinement or domestication. In their natural condition they give abundant proofs of their confidence in man, and their sensitiveness to his kindness.

I remember to have recently seen an account of a robin, whose nest, containing young ones, was attacked by a snake. The loud cries of the bird attracted the attention of a man who was working near the spot, when he went immediately to its assistance, and killed the snake. When its enemy was dead, the robin showed its gratitude to the preserver of its young in every way in its power, at the same time flying now and then, in a rage, to peck at the dead snake.

The celebrated French naturalist, M. Sonnini, has recorded the following pleasing incident which occurred during his passage from Malta to Egypt :-

Two little birds, one a grey wagtail, the other 
the garden warbler, perched upon the yards of the frigate, and, being quite exhausted. by the length of their flight, suffered themselves to be taken by the hand. At his request they were given to him, and he carried them to the great cabin, where he endeavoured to cheer the poor little wayworn voyagers by caresses and feeding. Finding them, however, too much alarmed to eat or repose, he let them loose.

"Whether they foresaw the storm which we encountered the following day," says he, "or whether, as no land was in sight, they were afraid to trust themselves to the open sea, I know not; but, after a few moments of uncertain flight, they returned by the same window whence I had let them fly. From that time they never quitted the cabin; and if, when frightened by any noise, they went out of one of the stern windows, or by a port, they were sure to come back by another. Although of different species, they lived in the greatest harmony; they played upon those terrible machines which deal death and destruction, and it was indeed upon a cannon that was placed their little provision of fresh water and crumbs of bread. It served them also as a roosting-place. Their confidence was unbounded; they fluttered over a table at which twenty persons somewhat noisy were daily seated; and with their chirping; 
and quick and graceful motion enlivened our monotonous abode.

" On our approach to the island of Candia our pretty and interesting navigators hastened to fly away, and took leave of us by uttering a few shrill notes, the sweet accents of their joy, and perhaps of their gratitude."

Under the influence of this instinctive confidence in the favour and protection of man, certain birds attach themselves to our neighbourhood, and seek the shelter of our habitations, beneath which to rear their young. This feeling seems to give them a sort of claim upon our sympathy and kindly usage, and I cannot help agreeing with Mr. Jesse, that the attacliment with which the robin is regarded by mankind, wherever he is known, is to be traced principally to this cause. The little redbreast loves to be near us, and to live under our shadow. He comes to us in his distresses not only for food and shelter, but as if he thought our companionship was more pleasant and comfortable to him than that of his fellows; and he is constantly proving it to be so by the cheery song with which he greets us in the most cheerless day, even in the depth of winter. We do not care to tame a robin, we rest satisfied with his natural philanthropy; and though in many respects he may be voted inferior to most of his 
feathered companions, still we love him best, simply because he is himself a lover of man. So thinks Mr. Jesse, and he has drawn with his lively pencil a most amusing picture of the pugnacious little fellow, whom he boldly pronounces the most unamiable among all known birds.

"I once saw," says he, " in a dining-room, by the side of an aviary, a little cage, with something in it, sitting on a perch, and therefore, as I supposed, a bird. But, although I went very near the cage, I declare that I could make nothing of it. I could see no head nor any eyes, which, so far, is perhaps the less to be wondered at because it was in London, and a London day in winter; but I could see no wings, nor feet, nor tail, nor even any feathers. I am satisfied that there was not one feather, nor the visible rudiments of one feather on its whole body, which was a round and raggec. ball of dirty down, like that of a duckling, only not of the same colour. Yet it was, or was all that remained of, a robin, who had been taken out of the aviary, in articulo, at the last gasp, to save his life, or what was left of it, because he did nothing all day long but fight indiscriminately with all the other birds, goldfinches, canaries, chaffinches, a tomtit, and several others. $\mathrm{He}$ took them as they came, and never gave them any peace, though a tomtit is a matsh for any bird of 
its own size, and I believe, indeed, that it was principally through himi, though purely in his own defence, that the robin had been reduced to the deplorable condition in which I saw him. If, therefore, we take from the prior claims of a robin, beauty, tameness, song, sagacity, and natural amiability, we shall find we cannot err in attributing our love for him solely to his having in the first instance loved us."

But I am exceeding due limits, and though, in order to attain anything like a perfect knowledge of this interesting subject, it would require a volume instead of a few pages, I must be content to leave it here, only observing, that the greater attention we pay to the various powers and faculties of animals, the more we shall be convinced that there is much yet to be learned as to the extent of those faculties. That there is a high degree of intelligence to be observed in them, and which is exhibited in very remarkable ways, is indisputable. Can we doubt, after watching them attentively, that they give proofs of being endower with the feelings of memory, joy, gratitude, love, sympathy, jealousy, and many other impulses which might be enumerated? Surely, the study of nature is well calculated to impress us with kindly feelings. Creatures susceptible of impressions produced by our actions are objects of bene 
volence, and claim to be regarded and treated as such. And the same study reveals the goodness of God, not only to us, but also to all his works. It is He who gives understanding and skill to the fowls of the air, and who cares for them, so that not one falls to the ground without him.

If these few introductory pages should give an impulse to any young readers to pursue the study to which I invite them, their object is attained. 



\section{BRITISH LAND BIRDS.}

\section{ORDER I.-RAPTORES.}

RAPACIOUS BIRDS, OR BIRDS OF PREY.

CHAPTER I.

Vultures, Falcons, and Owls-Solitary Vulture seen in England-Raptorial Birds-EAGLES-Two British species, the Golden, and the White-tailed or Sea Eagle.-Account of the Golden Eagle and his mate in their native hauntsTame Golden Eagles-The Sea Eagle, the Common British Eagle-Account of this bird in his fishing hauntsThe Patriarch Job's poetical description of the king of Birds.

THE formidable tribe of RAPACIOUs birds, or birds of prey, is the first in order among the feathered race.

Vultures, FAlcons, and owls, are included in it; but the first of these can scarcely be said to belong to our country, as only one is certainly known to have been seen and killed in England. This solitary case occurred in 1825 , or 1826 , in Somersetshire. A strange unknown bird, was, one day in the month of June, seen walking along a road near the sea-shore; evidently so gorged with food, 
that it could not fly without difficulty. On being pursued, it took to flight; but soon alighted again on the beach, and was shot. It was one of the smallest of the vulture kind, measuring only two feet, three inches, from the tip of the beak to the end of the tail; whereas, the great condor of South America sometimes measures twelve feet, from tip to tip, of its outspread wings.

The FALCoN tribe, is divided into numerous families. Eagles, falcons, hawks, kites, buzzards, and harriers; all of which have these distinguishing characters in common, by which they are readily known. The bill is strong, sharp, and much hooked; and is furnished with a naked skin at the base, in which the nostrils are placed. The head and neck are well clothed with feathers, while those of the vulture are more or less naked. The legs and feet are scaly, and the claws large and strong, hooked, and very sharp. Unlike most other kinds, the female of birds of prey is larger and stronger than the male.

It has been happily remarked that the rapacious birds, of which the EAGLE is the chief, bear a strong typical resemblance to the carnivorous animals. The dispositions of both are fierce and intractable, their frames are strong and sinewy, well adapted for swift pursuit and powerful action. The sight 
in both is remarkably acute, and the strong, curved and toothed beak of the birds, like the powerful teeth of the feline tribe, is admirably adapted for tearing; and their claws, large, curved and sharp, are equally fitted for holding and lacerating their prey.

The general purpose of both classes is to act as a salutary check upon over production; and birds of prey, like wolves and hyenas, perform the part of scavengers in removing dead animal matter, which would be, without their assistance, exceedingly hurtful to the living.

Among birds the predatory classes are endowed with a keener sense of smell than the graminivorous tribes; yet it seems to have been satisfactorily proved that they are, to a great extent, dependent on the sight for the discovery of their prey. Audubon stuffed a deer's skin with hay, and placed it in an open field, in the attitude of a dead animal. A vulture soon made its appearance. and perching on the stuffed skin, began to tear it open with all its force, but finding that it only drew forth grass, after many efforts, it abandoned its attempts with evident reluctance. Young vultures in confinement give no signs of perceiving the presence of their food, however near it may be placed to them, unless they see it; and thus, too, herons and other wading birds are guided by 
the sight to the selection of the best supplied fishing places.*

One of the most surprising facts connected with birds of prey is that wonderful acuteness of vision which enables the eagle, for example, when soaring aloft amid the clouds, to discern so small a bird as a partridge upon the ground. When looking for its prey the eagle sails in large circles, with its tail spread out, and its wings scarcely moving. Thus it soars aloft in its course, its gyrations becoming less and less perceptible until it dwindles to a mere speck, and is at length lost to view, when it suddenly reappears, rushing down like lightning, and carries off in its talons some unhappy prey.

The raptorial birds are endowed with a very beautiful modification of the eye in relation to this power of vision. The globe is surrounded with a circle of bony plates, slightly moving on each other, whereby its form is maintained, and the muscles at the back of the eye are so arranged, that, by their pressure, the front of the organ can be rendered very prominent, or they can be quite relaxed, and the front of the eye rendered nearly tlat. The first condition fits it for discerning near objects; the second endows it with telescopic 
sight, and is that which exists when the bird is hovering on high.*

The eyes of birds which fly abroad and seek their prey by night, are so incapable of bearing the light that they have only the full power of sight at twilight, and the pupil is then so distended that it admits an unusual proportion of the rays of light; a construction precisely similar to that which is found among animals of the feline species. In these, as well as among the other carnivora, the pupil appears like a perpendicular line, by which means the sight is more concentrated, and is remarkably keen in moments of excitement, and when the animal collects itself for the fatal spring upon its prey.

The feline races, having caught their prey, teach their young to destroy it, to tear it, and to revel in its blood; and their type, the eagle, goes one step farther, in teaching the power of flight. Sir H. Davy had an opportunity of watching the proceedings of eagles in this respect. He says, "I once saw a very interesting sight above one of the crags of Ben Nevis, as I was going, on the 20th of August, in the pursuit of black game. 'Two parent eagles were teaching their offspring, two young birds, the manouvres of flight. They

* See "Zoological Notes and Ancedotes," p. 277. 
began by rising from the top of a mountain, in the eye of the sun: it was about mid-day, and bright for this climate. They at first made small circles, and the young birds imitated them; they paused on their wings, waiting till they had made their first flight, and then took a second and larger gyration, always rising towards the sun, and enlarging the circle of flight, so as to make a gradually extending spiral. The young ones still followed slowly, apparently flying better as they mounted; and they continued this sublime kind of exercise, always rising, till they became mere points in the air, and the young ones were lost, and afterwards their parents, to our aching sight."

Colonel Maxwell witnessed a similar scene on the summit of Slieve More, in Ireland. On a huge and inaccessible crag, two sea eagles had formed an eyrie, where, for many years, they annually produced their offspring, to the sad annoyance of the neighbouring villagers. One morning the pair was observed descending from their rocky habitation, accompanied by two eaglets, evidently to teach their young to stoop and lift their prey. The old birds tore up turfs from the mountain side, rose high in the air and dropped them. The eaglets in turn, stooped, and took them up again. This was frequently repeated, and the course of instruction having lasted half-an-hour, the young 
mounted to their nest, while the parents sailed off upon the rising breeze to procure them a meal.

To black fowls the eagles appear particularly attached; and the villagers avoid as much as possible, rearing any of that colour. These birds are also extremely destructive to fish, and particularly so to salmon, as they are constantly seen watching the fords in the spawning season, and seizing and carrying off the fish. In the pursuit of hares they show a degree of intelligence that appears extraordinary, coursing them with great judgment and certain success; one bird is the active follower, while the other remains in reserve, at the distance of forty or fifty yards. If the hare by a sudden turn, free himself from his most pressing enemy, the second bird instantly takes up the chase, and thus prevents the victim from having a moment's respite.

When engaged in fishing they pursue a similar mode. Choosing a ford upon some rivulet, and posted on either side, they wait patiently for the salmon to pass over, and their watch is rarely fruitless.

Mr. White, of Selborne, thus admirably pictures the various modes of flight in virds of prey. "Kites and buzzards sail round in circles, with wings expanded and motionless; and it is from their gliding manner that the former are still 
called in the north of England, gleads, from the Saxon verb glidan, to glide. The kestrel, or windhover, has a peculiar mode of hanging in the air in one place, his wings all the while being briskly agitated. Hen-harriers fly low over heaths or fields of corn, and beat the ground regularly, like a pointer, or setting-dog. Owls move in a buoyant manner, as if lighter than the air; they seem to want ballast."

The author adds, "there is a peculiarity belonging to ravens that must draw the attention even of the most incurious ; (we have not many opportunities now-a-days of observing them;) they spend all their leisure-time in striking and cuffing each other on the wing, in a kind of playful skirmish; and when they move from one place to another, frequently turn on their backs with a loud crack, and seem to be falling to the ground. When this odd gesture betides them, they are scratching themselves with one foot, and thus lose the centre of gravity."

The eagle's cry is sharp and loud, and so powerful, that it can be heard from afar. Destined for war and plunder, it is fierce, bold, and indomitable. It is also believed to be long-lived. One that died at Vienna, was reported to have lived in confinement a hundred and four years.

The attachment of the eagle to his mate is 
strong, and endures for a lengthened period; probably, through life. The pair are always seen in company, or but at a short distance from each other; and they often unite their exertions in the pursuit of prey.

We have two British species,* belonging to the first, or aquiline branch of the Falcons. That noble bird, the GOLDEN EAGLE, one of the most powerful and the model of his race, is one of these. But it is very rare, and dwells only in the wild parts of our land. It is chiefly confined to Scotland, and its western and northern islands; and specimens of it have been found in Ireland. Even in the Highlands it is by no means common, and it is constantly becoming more scarce.

Its eyrie, or nest, is confined to the most wild and inaccessible places of the Grampians. This cradle for the young broods is placed on some ledge or shelf of a lofty rock, and requires a space of several feet square of surface, for the collection of strong sticks and roots of trees and heather, of which it is composed.

The femaic bird, which is (as before said) considerably larger than the male, lays two, sometimes three eggs-white, with pale brown, or purple spots. The young eaglets are watched, defended

* A third-the Spotted Eagle-has been once killed in Ireland. 
and provided plentifully with food, by the parent birds. The stores accumulated are almost incredible. Hares, lambs, the young of the deer and roebuck, grouse, and various game-birds, contribute to the feast.

The following striking lines give a vivid picture of the bird :-

"The tawny eagle seats his callow brood

High on the cliffs, and feasts his young with blood.

On Snowdon's rocks, or Orkney's wide domain, Whose beetling cliffs o'erhang the western main, 'The royal bird his lonely kingdom forms Amidst the gathering clouds and sullen storms. Through the wide waste of air he darts his sight And holds his sounding pinions poised for flight;

With glaring eye premeditates the war, And marks his destined victim from afar;

Descending in a whirlwind to the ground

His pinions like the rush of water sound;

The fairest of the fold he bears away,

And to his nest compels the struggling prey."

The eagle usually strikes his prey upon the ground, and the blow is almost instantly fatal to any animal on which he pounces. He shoots down from an immense elevation, with lightninglike velocity, and strikes his claw into the body of the animal, up to the toe, so as to inflict a deadly stroke. The swoop is slanting, and the main blow is given with the eagle's hind toe.

The rapidity with which a strong bird of prey flies in pursuit of his quarry, is inconceivably 
great; the flight of a hawk is calculated at a hundred and fifty miles an hour; and the anecdote of the falcon belonging to Henry Iv. of France, which flew in one day from Fontainebleau to Malta, a distance of 1350 miles, is well authenticated.

The sight of the bird must be as steady as acute; for he seldom misses his mark when on the ground; although he often fails when he attempts birds on the wing, being unable to follow the short and rapid turnings of their flight.

The strength of endurance in the eagle is surprisingly great, enabling the bird to sustain existence under circumstances that would destroy almost every other animal. In winter, when the ground is covered with snow, he remains for days without food, and bears the severity of the cold and the wintry winds, clinging to the pinnacle of the rock, as though part of the rock itself: and braving the tempests that scatter ruin around.

An admirable picture of this bird is that drawn by the late Bishop Stanley. $\mathrm{He}$ has thus described what he was himself fortunate enough to see. "While climbing some high precipices in the volcanic district of Auvergne, in France, near a great waterfall, which dashed downwards with a thundering noise; in the midst of the loud roar of waters, a short shrill cry met our ears, coming, 
as it were, from the clouds. On looking in the direction from which it came, we soon perceived a black speck, moving steadily on towards us. It was a golden eagle, evidently coming from the plain countries below; as he drew nearer we could see that his wings scarcely ever moved; he seemed to float or sail in mid-air, rather than fly; though now and then, indeed, they slowly flapped, as if to steady him. As he was approaching in a direct line, we hid ourselves behind a rock, and watched his motions through a telescope. When first seen he could not have been at a less distance than a mile; but, in less than a minute, he was within gunshot, and, after looking round once or twice, he darted down his legs, slightly quivered, and alighted on a rock within a few yards. For a moment he gazed about with his sharp, bright eyes, as if to assure himself that all was safe; he then, for a few moments more, nestled his head beneath one of his expanded wings, and appeared to plume himself. Having done this, he stretched out his neck, and looked keenly and wistfully towards the quarter of the heavens from whence he came, and uttered a few rapid screams; then, stamping with his feet, we saw him protrude his long, hooked talons, at the same time snapping his hooked beak, with a sharp jerking noise, like the crack of a whip. There he remained for 
about ten minutes, manifesting great restlessness, not a single instant quiet; when suddenly he seemed to see or hear something and, immediately rising from the rock on which he stood, launched himself into the air, and floated away, as before, uttering the same shrill cry. Looking round, we beheld the cause of his emotion; he had seen his mate approaching. He rose to meet her; and, after soaring in a circle a few times, they went away, and were soon invisible to the naked eye."

Perhaps some readers may ask, "Why is this eagle called 'golden?'" This is a very natural question, looking at one in confinement, or at a stuffed specimen. But when we read the following description of the bird, in full plumage, free, and joyous, in its native haunts, we can perceive how it came to be thus called. "It is very difficult," says Mr. Mudie, "to obtain even a tolerable portrait of one. For, in order to get the eagle in perfection in an aviary, we should require to bring the mountain crag and glen along with it. The bird lives, indeed, but its plumage is dull and its spirit still more so. The rich browns, with their peculiar metallic lustre, and the pointed feathers on the neck, shaded off till they arrive at a rich orange at the points, and stand up when the bird is excited, as if they were so many scalès margined with gold, are not to be 
obtained, unless where the bird has the free and unrestrained range of all its powers."

Several instances have been recorded of children being seized and carried off by eagles to their young; and a few such cases seem well authenticated as having happened in our own country. Ray relates, that in one of the Orkneys, a child of a year old was seized in the talons of an eagle, and carried about four miles, to its nest. The mother, knowing of the place, pursued the bird, found her child there, and took it away, unhurt! In the 'British Zoology' this curious statement is given :- "It is very unsafe to leave infants in places where eagles frequent, there having been, in Scotland, instances of two being carried off by them. Happily the theft was discovered in time, and the children restored unhurt to their affrighted parents. In order to extirpate these birds, there is a law in the Orkney Isles, which entitles any person who kills an eagle, to a hen, out of every house in the parish in which it was killed." This was written in 1775 ; no wonder eagles have become so scarce now-a-days.

The eagle has been called “indomitable," but, in some rare instances, even he, the proud wild king of birds, has become docile; and, while writing this, we cannot help remembering the words of the apostle James: "Every kind of 
beasts, and of birds, and of serpents, and of things in the sea, is tamed, and hath been tamed of mankind." A case in point is thus given ;*-

"Richard Langtrey, Esq., has at present a bird of this species (the golden), which is exceedingly docile and tractable. It was taken last summer from a nest in Inverness-shire. The bird became at once attached to its owner, who, after having it about a month, ventured to give it liberty, a privilege which was not abused, as it came to a lure whenever called. It not only permits itself to be handled in any way, but seems to derive pleasure from the application of the hand to the legs and plumage. When this bird is at large, my friend has only to hold out his arm to it, which, as soon as seen, even from a distance, it flies to, and perches on. It is more partial to alighting on trees than the sea eagles (which are also kept); and, stationed on their tops, keeps its master in view, following hirn about the grounds, flying from one plantation to another, in the direction he walks, and indolently remaining, as long as possible, where it perches, so long as it keeps him in view."

Another instance is known of an eagle captured in Ireland, after it had attained maturity, which speedily became domesticated and firmly attached to the place where it was fed, to which it always * In the Mag. of Zoology and Botany, vol. ii., p. 46. 
returned, though perfectly at liberty. Its wings had, indeed, been cut when first brought thither, but they were allowed to grow again; and this magnificent bird, on recovering the use of them, would repeatedly soar away and absent itself for a fortnight or three weeks. It became very much attached to those who were in the habit of feeding or caressing it. Its food was chiefly crows, which were shot for it; sometimes it attempted to procure them for itself, but never successfully, as their agility in turning shortly and rapidly, enabled them to elude its superior strength of wing ; latterly, therefore, it contented itself with eyeing them wistfully, as they flew or perched securely over its head. It was never suspected of committing any havoc among the folds in the adjoining field; but when, from some accident, its regular food had not been supplied, it would seize on and kill young pigs. Children, who constantly met it as it walked about in the garden, were never molested. At. length, after having lived nearly twelve years in this way, this interesting bird was killed by a ferocious mastiff. No one saw the battle, but it must have been fierce and long-contested, for the dog, though victorious, was so much injured that it died almost immediately afterwards.

The SEA EAGIE, or, as it is sometimes called, the 
WHITE-TAILED EAGLE, which is also a native of Great Britain, is much more common than the golden, and Mr. Yarrell says, ". . . may be seen frequently on some part of the coast, inhabiting the high rocks and cliffs that overlook the sea, from whence it keeps a look-out; and, when hungry, is equally ready to seize either fowl or fish, and has been seen to attack and feed on seals. It also shows a great partiality for fawns and venison, and is sometimes killed in deer-parks and forests."

This eagle builds its nests on high rocks, ard lays two eggs. It breeds in the Shetland Isles and also in Ireland and some other localities, and is much more numerous in winter than in summer; hence it seems probable that this species is migratory.

A pair of Skua gulls were once seen to chase, and completely beat off a large sea eagle. They struck at him several times, and at each stroke he screamed loudly, but never offered to return the insult.

This species is probably the only eagle now to be met with in England, in a natural state. It is the one most generally seen, and is "the eagle" of common conversation all over Britain; hence many of the anecdotes usually told of the golden eagle really belong to this kind.

According to Mr. Mudie, the most favourite resort of this bird is the western part of Ross, 
that tract of country being well adapted to its habits. The aspect of the land is desolate and wild; dreary, black morasses abound, precipitous rocks, with peaks rising high aloft; a shore full of little bays and inlets; lakes, studded with islets: a temperature as variable as the weather, which is so rainy that the people are said to be aquatic, and to catch cold whenever they come so far eastward as to get dry; and a soil continually torn and ploughed up by rains and floods. Such is the country. 'The results are a richness of vegetation and a superabundance of animal life that must be seen to be realized. Here the waters teem with fish, and the land with all sorts of living creatures, to which so moist a climate is suited. Salmon, trout, herring, and cod abound; and here the sea eagle finds the richest harvest.

This account of the king of birds cannot, perhaps, be closed more appropriately than with that life-like picture of the bird, which was given thousands of years ago to the patriarch Job:--

"Doth the eagle mount up at thy command, And make her nest on high?

She dwelleth and abideth on the rock,

Upon the crag of the rock and the strong place.

From thence she seeketh her prey, And her eyes behold afar off.

Her young ones, also, suck up blood, And where the slain are, there is sho." 


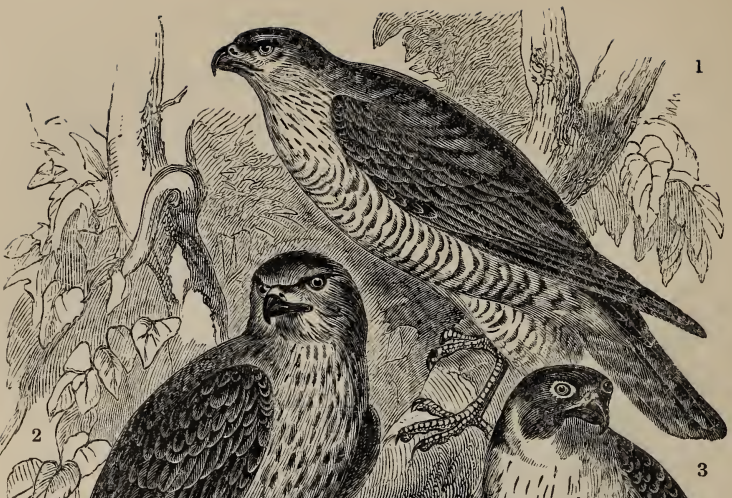

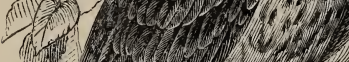
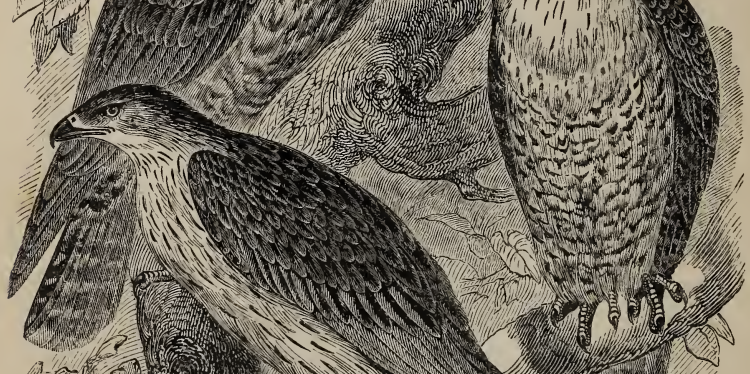

17

2 .

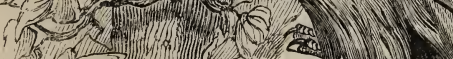

(1)

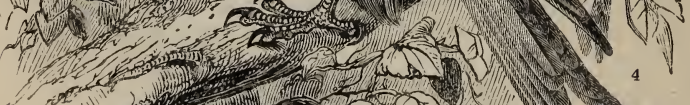

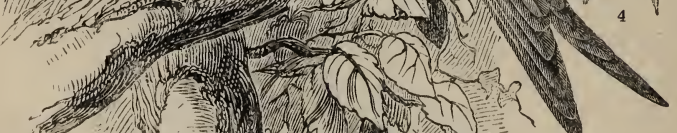

(s)

1. Sparrow-hawk, 2. Buzzard. 3. Peregrine Falcon. 4. Kite. 


\section{RAPACIOUS BIRDS, OR BIRIS OF PRFY.}

\section{CHAPTER II.}

The Osprey, or Fishing-Hawk - The Falcons. Seven British species of Falcons-The Gyr Falcon-The Peregrine Falcon trained for hawking - Some account of British Falconry-The Hobby, and the Merlin FalconsThe Kestrel, or Windhover-Description of this bird, and anecdote of a Cat and a Kestrel-The TrIBE OF HawksTwo British species of Hawks - The Goshawk-The Sparrow-Hawk-Common in England-Two anecdotes of this bird, showing its tameness and love of sweet soundsThe Kite-A description of this bird-The Buzzard-The HARRIERs-Three British species of these birds--The Marsh Harrier-The Hen Harrier-Montagu's Harrier.

THE OSPREY, or fishing hawk, partakes of the characters both of the eagle and the falcon, and forms a sort of link between the eagle and the kite.* It lives almost exclusively on fish, which it seizes with its claws, plunging into the water, and bearing off its prey. The whole structure of this bird is most beautifully and admirably adapted to its habits. The outer toe is flexible, and can be turned either way so as to enable it to clutch what it seizes firmly; the claws are strong, curved, and sharp, and it has a peculiar roughness in the soles of its feet, by which it is secured from dropping

* The Oriental hawks of the genus IIaliaëetus are half ospreys and half kites. 
its slippery prey. It is not common, but is met with in Scotland, and occasionally on our English coasts.

The manner in which the osprey seeks its prey, and its mode of obtaining it, are admirably described by the ornithologists of America, in which country this bird abounds. On one island near the eastern extremity of Long Island, New York, three hundred nests were counted. The old birds were rearing their young close together, living as peaceably as so many rooks, and were equally harmless in reference to other smaller birds. When looking out for its prey, the osprey sails with great ease and elegance in curved and undulating lines, at a considerable height above the water, from whence it precipitates itself upon its quarry; and not unfrequently, on the fish moving to too great a depth, stops suddenly in its descent, and hovers for a few seconds in the air, suspending itself in the same spot by a quick flapping of its wings. It then makes a second, and generally unerring, dart upon its prey, and regains its former altitude by an elegant spiral flight.

The poet-naturalist, Wilson, gives a spirited description of the manner in which the eagle of America, which is remarkable for his great partiality to fish, turns the industry of the osprey to his own account by robbing it of its prey. He 
paints the kingly bird perched on some lofty eminence, from whence he surveys the neighbouring shore and ocean, and calmly watches the motions of the various feathered tribes that pursue their busy avocations below. The snow-white gulls, slowly winnowing the air; the busy tringoe coursing along the sands; trains of ducks skimming the surface; silent and watchful cranes, intent and wading; and all the other winged multitudes that subsist on the stores of this vast liquid magazine of nature.

"High over all these hovers one whose action instantly arrests all his attention. By his wide curvature of wing and sudden suspension in the air, he knows him to be the fish-hawk, settling over some devoted victim of the waters. His eye kindles at the sight, and balancing himself with half-opened wings on his branch, he watches the result. Down, rapid as an arrow from heaven, rushes the osprey, the roar of his wings reaching the ear as he disappears in the deep, making the surges foam around. Presently he emerges, struggling with his prey, and mounting upward. Instantly the eagle gives chase, and soon gains on the fish-hawk, each exerting himself to mount above the other, displaying in the effort the most beautiful aërial evolutions. The unencumbered eagle rapidly advances, and is just on the point of 
reaching his opponent, when, with a sudden scream, probably of despair and execration, the latter drops his fish. The eagle, poising himself for a moment as if to take a more certain aim, descends like a whirlwind, snatches it in his grasp, ere it reaches the water, and bears his ill-gotten booty silently away to the woods."

Of the true Falcons (which give their name to the whole family) we have seven species in England, of which four are regular visitors, namely, the peregrine, the hobby, the merlin, and the kestrel ; and three only occasional, namely, the gyr falcon (or Iceland falcon), the Greenland falcon, and the orange-legged falcon.

The GYR (or Iceland) FALCON is the largest in size, and possesses great courage and strength. Large sums were formerly expended in procuring specimens from Iceland and Norway for the purposes of falconry, and it was usual to fly them at birds of large size, such as cranes, storks, and herons. This is not a numerous species anywhere, and is very rare in our island, being merely an accidental visitor. The mature plumage of the Iceland falcon is white, with bars or dashes of brown, somewhat resembling that of the snowy owl.

The PEREGRINE FALCON is one of the strongest 
and most beautifully-formed birds of the kind; and though not common, can scarcely be said to be rare in this country. Several of the falcon and hawk species have been made useful to mankind by being trained to catch game of various sorts ; and from very early days, great pains have been taken in rearing them, by people of many nations. The peregrine, being the commonest species, and possessing considerable courage, power, and tractability, is the falcon, specially, of falconers. In the language of falconry, the female bird is always called the falcon; the male is called the tercel. The "gentil falcon" is the term used-in opposition to "low," or "vulgar," denoting the superiority of the bird, which never stoops (like some inferiors of the race) to ignoble game. This bird is said to owe its name (peregrine) to the length of its onward flight, which is also exceedingly rapid. Montague says it flies a hundred and fifty miles an hour.

The heron is the hardest game of the falcon in this country, because of the height at which it flies, and the consequent difficulty of the falcon in getting above it, and the small power it has over any bird that is lower than itself. The heron strives hard to keep above its enemy, because, while it does so, it is perfectly safe. When, however it is mastered in that, it has still the resource 
of charging, by doubling back the neck, and projecting its sharp-pointed bill upwards, by which means it preserves the head and neck from the falcon's stroke, and also presents a point, on which, should she strike, she would be transfixed, and the heron escape in safety; as does actually sometimes happen.

No amusement seems to have been followed with so much eagerness as that of hawking, in almost every country of Europe, and from the earliest times, even before William the Conqueror's days, it was the favourite pastime of the magnates of England. Every young man of rank was taught the mysteries of the art of falconry; king Alfred is said himself to have written a treatise on the subject, and even ladies followed the sport as eagerly as gentlemen; the amusement being occasionally pursued on foot, but generally on horseback.

In consequence of the disappearance of wastes and commons, by inclosures and hedges-which renders it no easy matter to follow the amusement without danger and delay-and also, ever since the introduction of guns, hawking has gradually declined, and may now be said to be nearly at an end, though within late years some attempts have been made to revive it.

Sir John Sebright, in his "Observations on 
hawking,' written 1826, has described the mode of flying peregrine falcons at herons, as then practised in Norfolk; and a new work on British Falconry has just been published by Mr. Salvin, an amateur of Yorkshire. A few English hawks are annually trained in the neighbourhood of Bridport in Dorsetshire, for the taking of landrails in the hemp or flax fields near that town, in which, during some summers, those birds are very plentiful.

In Russia, there still exist the practices of the old chase, and all the mysteries of falconry are studied and understood by the grand seignors, who keep up the traditions of their ancestors. Their love of hunting is probably derived from their Scythian progenitors or from the Tartars, whose khans took great delight in the pursuit of beasts of prey by dogs and birds. The large Iceland falcons and all the long-winged hawks are trained with great care, and several establishments of the kind are well known and celebrated in Russia for the excellence of the birds brought up within their precincts.

In Siberia, several very strong, fierce, and swift hawks, larger than gyr falcons, and of great courage and beauty, are found, which are held in much esteem, and are sold at high prices. These birds will pursue a fox, and strike out his eyes 
and kill L.m and it is affirmed that two of them will attack a wolf, blind him by strokes of their wings and beaks, and then destroy him at their leisure with their powerful talons.

The поввт, a true falcon, though of small size, may be considered as a peregrine falcon in miniature, but is rather more slender in its proportions. In this country it is a summer visitor, and, though well known, is not very numerous. It prefers wooded districts, where it builds its nest on high trees. The food of this species is small birds and large insects.

The MERLIN though one of the smallest of the British falcons, is possessed of rapid flight and great courage, attacking and retaining its hold on birds far superior to itself in size and weight. It has been known to strike a partridge, certainly more than twice its own weight, dead, with a single blow. It skims, like a swallow, over the ground, with surprising swiftness. In the days of falconry this species was much valued. It is a winter visitor in the southerm parts of this country, and breeds in some of the northern counties. In the adult bird the back and wings are of a fine blue grey, whence the poet sings,-

"The elfin king, like the merlin's wing Are his pinions of glossy blue."

Of the inferior grade of falcons is the KESTREL (or 
windhover), one of the most common of our birds of prey. It is handsome in shape and plumage, and graceful in its motions, and is best known by its remarkable habit of poising, or, as it were, anchoring itself over a particular spot, despite the wind; whence it has obtained its popular names of "windhoverer," or, hoverer in the wind; and stangel, or "stand-gale." While it is hovering, the motion of its wings, when they move, is exceedingly rapid; its head, at the same time, is bent downwards and turned sideways, so that the eye can command a wide circle of the ground over which the bird is hovering. Its sight is so acute that not a mouse can stir within range but the kestrel pounces on it, with almost certain accuracy. It also kills small birds, as the following anecdote proves. One of them was observed to seize a young blackbird, just able to fly, which it was in the act of carrying off in its talons, when the old blackbird gave chase, with loud cries and apparent determination to rescue her young one. The kestrel, having allowed her to approach unmolested, in an instant dropped the young bird, and as instantaneously caught up the screaming parent, and carried her clear away.

In the 'Zoologist' for 1853, there is a curious tale of a cat and a kestrel. The bird, being kept in a garden, with his wing cut, contracted a 
friendship for a cat frequenting the same premises, which the latter reciprocated, and was seen to bring a live mouse, and put it down before her friend the kestrel, who immediately attacked and devoured it; puss in the meantime sitting by, at a short distance, complacently watching the enjoyment of her ally.

The tribe of HAWKS is distinguished from the falcons by the difference in the bill, which, though strong and curved, is destitute of the sharp tooth so remarkable in that division, and also by the short and rounded form of the wing; which reaches only half-way down the tail. There are two British species, the goshawk and the sparrow-hawk.

The GosHawK, equal in size to the largest of the falcons is inferior in powers to them, and its habits and mode of flying at its game, are very different. It does not stoop at its prey, like the falcons, but glides along in a line after it, a mode which, in the language of falconry, is called raking. The goshawk was formerly in esteem among falconers, being, though naturally very wild, not difficult to train. It has the habit, when it fails in catching its prey, of perching on a bough, and watching till some new game presents itself. It will remain patiently if the object of its pursuit 
be driven to covert, waiting and watching until the game, pressed by hunger, is induced to move; and it generally succeeds in its object in this manner, from its greater powers of abstinence.

The goshawk is now very scarce in England, being nearly confined to the mountainous parts of Scotland, where it breeds, and is said to be a great destroyer of game.

The SPARROW-HAWK is of small comparative size, and may be called a goshawk in miniature, its habits being very similar. It is a common and well-known species in most of the wooded districts throughout this country. Bold, active, and impetuous, it is very destructive; a dangerous enemy to small quadrupeds and young birds, and is not unfrequently known to thieve from the barn yard.

Though shy and untractable, this bird has proved in some instances tameable; and an interesting case in point is given by Bishop Stanley. A young sparrow-hawk was procured and brought up by a person who was fond of rearing pigeons. The hawk, by management and kindness, was at length brought to form a sort of friendship with the pigeons, and to associate with them. At first the pigeons were naturally shy at so close a contact with their enemy, but they soon became used to bim, and approached without fear. It was 
curious to observe the playfulness of the hawk, and his perfect good-humour at feeding-time. He attended the pigeons, after the meal was over, in their flight round the house and gardens, and at night retired with them to the dove-cot. Nor was he ever known to touch a young one. $\mathrm{He}$ seemed quite unhappy if separated from his companions, and would utter melancholy cries when purposely shut up alone, which were exchanged for notes of joy and pleasure when any person familiar to him entered the place. The narrator of this account added, "he was as playful as a kitten and as loving as a dove."

A similar instance is recorded of a pet sparrowhawk which used to strut about the yard where the poultry were kept, without being feared or regarded. During a severe winter this bird walked with the pigeons into their house at night, and slept in their dwelling; and, though there was a numerous flock of old and young birds, not one was ever missed. It was long a matter of wonder to the family to whom this bird belonged, why he used to approach the window-sill of the room when the piano was being played, and at length come quite in. On one occasion he was placed on the edge of the instrument, for the sake more of seeing him ruffle his feathers than from any expectation of giving hirn pleasure. He stood there 
for a considerable time, evidently listening with great delight, and being unwilling to remove. After that, he frequently perched on or near the piano, clearly for the sake of enjoying "the concord of sweet sounds."

The kITE is a bird readily distinguished, even at a distance, on the wing, by its long and forked tail. It was formerly a common and well-known bird with us, but it has now become rare in England, a constant war of extermination having been carried on against it, as well as its fellows in general, by the game-keepers. In the olden dirty times, this bird was the scavenger of the English cities; and it was once so common in some parts of Scotland that children used to be posted to watch for and "sheu" them, armed with a watchman's rattle; and not without good reason; for, as Bewick quaintly reports, "the kite is particularly fond of young chickens," - a rather unfortunate propensity.

The flight of this large bird is singularly graceful and easy; and it has obtained its provincial name of "gled" or "glead," from its gliding movement, so soft and smooth, with outspread but motionless pinions. It has been thus described by a loving observer of nature. "The sight of a kite, quite at its ease (or at its labour, if you will), on a clear fine day, and when there is 
not a spot in the blue dome of heaven but itself, is really a very fine one. It appears as if it had charmed the atmosphere to move as it lists, and without any effort. The wings and tail are expanded, and yet they appear hardly to move, as the bird ascends and descends, and wheels and turms, now in wide sweeping circles, and anon, dropping down, it turns fairly round on the point of the wing, as a pivot. After it has been beating over one pasture without success, and there is a hill or wood, or any place not adapted to its habits to be passed over, before it can reach its nest, the beauty and easy smoothness with which it gets up, are unrivalled. It climbs eagle's height, without eagle's effort, and from the very top of heaven surveys the land, then shoots away to some distant places better adapted to its purpose."

One of the most common of the larger kind of hawks which inhabit the wooded districts of this country is the BUzzard. It feeds on small quadrupeds and birds, and is of considerable size and strength, but its courage and energy are by no means equal. It is sluggish and inactive, and slow in flight, seemingly preferring to watch from a tree, the accidental approach of some animal. rather than to hunt abroad for game. When pressed by hunger it may be seen soaring in the 
air, in easy undulations, over the fields close by the woods it inhabits. It builds in old trees, not unfrequently taking possession of the deserted nest of some other bird. The general length of the buzzard is one foot eight or ten inches. The plumage is subject to great variation, the upper parts usually of a deep brown, and the lower of yellowish white, spotted with brown or reddish dashes.

'The last section or tribe of this family is that of the HARRIERS; which are birds of considerable size and power, and very active in the pursuit of their prey. Their flight is easy, graceful and buoyant, but rather slow and near the ground. These birds have a singular mode of hurting over the surface, like a dog in search of game, whence they have probably got their name, They are also sometimes called "harpies." There are three British species of harrier-the marsh, the hen, and the ash-coloured (or Montagu's) harrier.

The largest and most powerful is the MARsH HARRIER, which, as its name implies, frequents marshes and uncultivated heaths and moors. It is not uncommon in this country in the fenny districts; its prey being small quadrupeds, waterbirds, and reptiles. This silent-winged marauder skims along the ground, and suddenly drops upon 
its prey, seizing the victim with its sharp claws as it passes. Not unfrequently it may be found beating over rabbit-warrens near marshes or on the shores of the sea; and it prefers the early morning or the evening after rain, when the young rabbits come out to feed in the greatest numbers. The female is about one foot seven or eignt inches in length. The general colour of the plumage is deep reddish-brown, the crown of the head being yellowish-white. The male is smaller, and lighter in colours, as is the case with all the species of this genus.*

The HEN-HARRIER is so called on account of its supposed partiality for the young broods of the poultry-yard. It is also very destructive in preserves, having courage and strength enough to pounce upon and kill a partridge, a red grouse, or even a pheasant. The sexes in this species differ so much both in size and plumage, that they have been often described as different birds. The male, from his almost uniform ash-grey

* The Rev. Richard Lubbock, says, "Twenty years back this bird might have been called the Norfolk hawk; it was so generally dispersed amongst the broads. Almost every pool of any extent had its pair of them; they consumed thie day in beating round and round the reeds which skirted the water. This was done for hours, incessantly. All the birds wounded by the sportsman, fell to the share of the moor-buzzard.' 
colour, is called, provincially, the dove-hawk, and the blue-hawk. The female is called a ringtail, and is reddish-brown. The head has a circular ruff of spotted feathers round the face, which gives it an expression quite distinct from any other of the tribe.

The hen-harrier, though nowhere very numerous, is pretty generally distributed in England, Ireland, and Scotland. The favourite haunts of the bird are upland heaths and warrens, which it prefers to marshes.

MonTaGU's HARRIER is easily distinguished from the preceding by being much more slender in shape and not nearly so heavy, its average weight being about nine and a quarter ounces; that of the hen-harrier about thirteen ounces. In their habits and haunts they are very similar. 
RAPACIOUS BIRDS, OR BIRDS OF PREY.

\section{CHAPTER III.}

Owls-Nine British species of Owls-The Snowy Owl, the king of his tribe-The Barn, or White Owl, the most common and useful of our British Owls-Entertaining account of a colony of these birds-Kee-vie, the Tame Owl-The Ivy, or Tawny Owl-Inhabits Woods and Forests-Scriptural references to the $\mathrm{Owl}$.

There is still another family to be classed among the rapacious birds, and forming a natural link in the chain after eagles and falcons; namely, owLs. The chief peculiarities of this tribe consist in the advantages afforded them in their structure, for seeing, flying, and hearing. Some of the birds we have already noticed seek their prey in different degrees of light, and their eyes are nicely adapted to meet their peculiar wants in this respect. The night birds of prey have very full and large eyes, and the iris is much more susceptible than in the day-birds; so that, in a strong light, the bird seems partially to close the pupil and be half-blinded, and, as it were, bewildered. By this peculiarity, the eyes of the owl can be adjusted to the various degrees of light it encounters while in search of prey. 

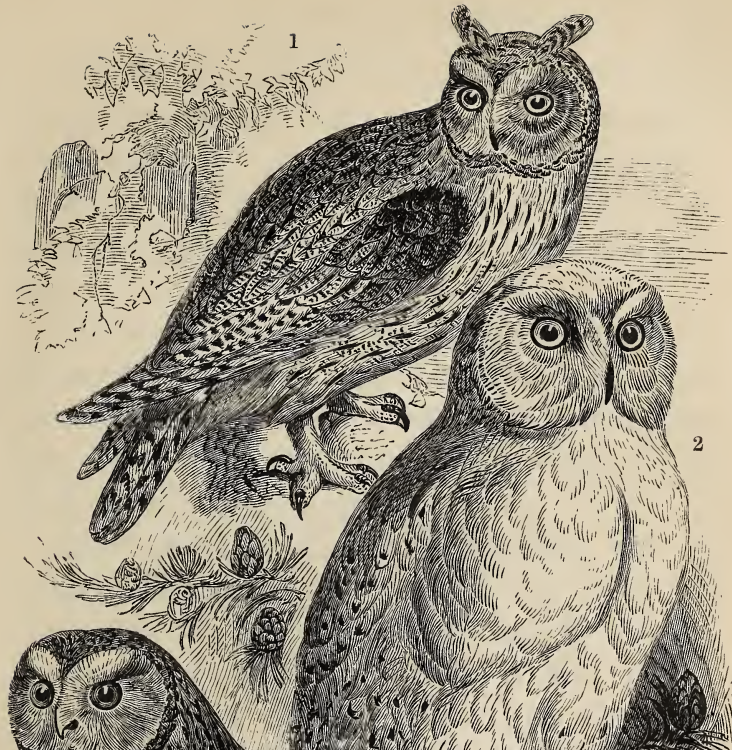

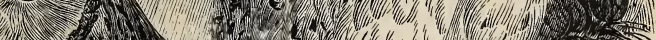

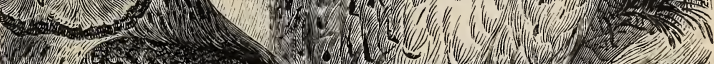

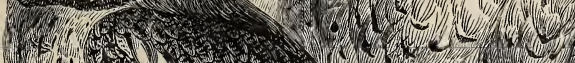

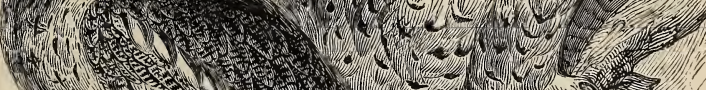

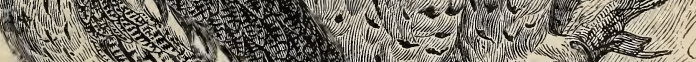

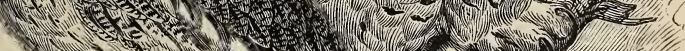

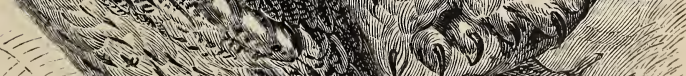

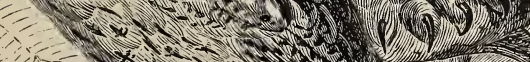

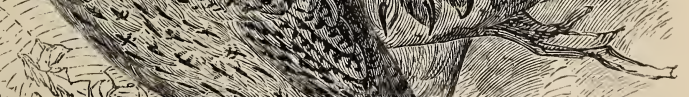

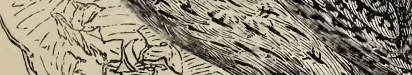

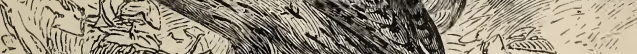

- 1 (1) (1) 3 , :

1. Iovgenaren OWL. 2. SNowx OWh. 3. TAWNy OWL. 

The softness and pliancy of the owl's feathers are also remarkable, fitting it to move noiselessly through the air. Its plumage is so very abundant it looks a thick, stout, even clumsy bird, but when stripped of its feathers it is surprisingly small.

The ear of the owl is exceedingly susceptible, being very large, and of peculiar form, with a sort of double valve outside, which can be thrown apart so as to concentrate, as well as easily admit, every slight vibration of the air.

Thus softly gliding on noiseless wing, with its huge acutely-seeing eye, and sharp ear, the owl is well-fitted for his work, which is to hunt the meadows and hedge-banks with the regularity of a pointer-dog, in search of mice, young rats, small birds and insects.

The very name of this bird is associated with gloomy and solemn ideas. Its note, deep, monotonous, and sad, has been well called " one of the most melancholy love-songs in the whole chorus of nature." The time of its appearance too-the mysterious twilight hour; its ghost-like flittings to-and-fro; its secluded habits and favourite haunts in hollow trees, crumbling ruins, steeples, and church-yards; all have combined to procure for it a superstitious dread among the ignorant.

Yet the owl is in reality an interesting bird: 
one of the most harmless, and even useful of the feathered race. The immense number of vermin it destroys is incredible; and it thus preserves the crops from one of their greatest dangers.

A striking instance of the usefulness of owls in this respect, occurred several years ago, in Somersetshire, when, in the course of the summer, a countless host of mice having overrun the country so as to threaten the destruction of vegetation, their ravages were checked by the sudden arrival of an assemblage of owls, which resorted from all parts, in order to prey upon them.

There are nine different species of owls, more or less frequenting this country; four of which have feathers on the sides of their heads, which they raise so as to resemble ears or horns; whence they are called " horned owls." These appendages, however, are neither ears nor horns, and have nothing whatever to do with the real ear. The other five species, being without these feathers, are called "smooth headed."

Of these nine species four are regular visitors; they are the barn, the ivy, the long-horned, and the short-horned owl. The remaining five species are accidental; they are the eagle, the snowy, the little, Tengmalm's, and Scop's owl.

By far the most beautiful of these is the sNowy owL, which may be fairly called, for its noble 
appearance, the king of owls. It is a rare visitant in England; its favourite home being among the verpetual snows of the northern regions. Its thick feathery coating makes it impervious to the intensity of the cold, and its dazzling plumage renders it almost invisible as it skims along the snowy plains; so that it can approach its prey unawares.

But the most common, familiar, and useful of all British owls, is the BARN, or wHITE owL.

"The owl that, watching in the barn, Sees the mouse creeping in the corn, Sits still, and shuts his round blue eyes As if he slept-until he 'spies The little beast within his stretch-Then starts, and seizes on the wretch!"

This bird, instead of avoiding man, comes close to his dwelling, and often frequents the barns and sheds of the farmer, whose true friend he is.

Mr. Waterton, a naturalist of note, paid the greatest attention to the habits of this bird, and has given a very interesting account of them, and the benefits it confers on man. He says:"'This pretty aërial wanderer of the night often comes into my room; and after flitting to-and-fro, on wing so soft and silent that he is scarcely heard, he takes his departure from the same window at which he had entered. I own I have a great liking 
for this bird; and I have offered it hospitality and protection on account of its persecutions, and for its many services to me."

After lamenting the evil consequences to his favourite, of the old and deeply-rooted prejudices everywhere entertained against him, Mr. W. says, "Amongst the numberless verses which might be quoted against the family of the owl, I think I only know of one little ode which expresses any pity for it. Our nursery maid used to sing it to the tune of the 'Storm,' 'Cease, rude Boreas, blustering railer.' I remember the first two stanzas of it:-

“Once I was a monarch's daughter, And sat on a lady's knee, But am now a nightly rover, Banish'd to the ivy tree; Crying, hoo, hoo, hoo, hoo, hoo, hoo,

Hoo, hoo, hoo, my feet are cold! Pity me, for here you see me, Persecuted, poor and old."

Mr. Waterton resolved that he would respond to this appeal for compassion which his infant ear had eagerly drunk in, and which, it should seem, he never after forgot. He accordingly, in the year 1813, after his return from America, commenced his friendly operations on behalf of the poor owls in his park, which, till then, had " had a sad time of it," owing to the popular prejudices 
against them. He made a sort of dwelling for them, on the ruins of an old gateway, and trained some ivy round it, so as to conceal the place. In about a month after everything was ready, a pair of barn owls came and established themselves there. This succeeded so well, that he provided similar places, which were also occupied by owls. He so contrived the first recess in the gateway that he could examine it whenever he pleased, and the birds, confident of protection, soon betrayed no fear when strangers mounted up to take a peep into their abode.

There was now an opportunity to study the habits of the owls. Several broods of young ones were brought off, and a rather unexpected piece of information was obtained ; namely, that these birds, unlike others, breel at all seasons, as he found a brood hatched in September, and another in December. It appears that the barn owl sleeps standing. The noise mistaken by many for snoring, is the cry of the young birds for food. This bird occasionally preys on fish.

Mr. Waterton says, "Some years ago, on a fine evening, in the month of July, long before it was dark, as I was standing on the middle of the bridge, and minuting the owl by my watch, as she brought mice into her nest, all on a sudden she dropped perpendicularly into the 
water. Thinking that she had fallen down in epilepsy, my first thuughts were to go and fetch the boat; but before I had well got to the end of the bridge, I saw the owl rise out of the water with a fish in her claws, and take it to the nest."

There can be no doubt that if this useful bird caught its food by day instead of during the night we should have ocular proof of its value in thinning the country of mice, and it would be protected and encouraged everywhere. It is said that when satisfied, this owl will hide the remainder of its meat like a dog. It is common in most, if not in all, the counties of England. In Scotland it is less numerous, and appears to decrease in numbers as we approach northward.

The following particulars respecting a tame white owl, are taken from the Rev. L. Jenyns" "Observations on Natural History." A young one was taken from a nest in the woods at Dilstone, in Northumberland, and given by a lady to leer children, who brought it up. Great pains seem to have been taken to domesticate this owl, which consequently became very familiar. In imitation of its own cry, it received the name of "Kee-vie" to which it readily answered when within call. It usually reposed during the day under the branches of an old Scotch fir, where it remained apparently in a sleeping condition, unless called, 
when it would rouse itself, and come in hopes of being fed. One of its most striking peculiarities is said to have been its great fondness for music. It would often come into the drawing-room of an evening, on the shoulder of one of the children, and, on hearing the tones of the piano, would sit with itseyes fixed gravely upon the instrument, and its head on one side, in an attitude of attention; when, suddenly spreading its wings, it would alight on the keys and making a dart at the performer's fingers with its beak, would continue hopping about as if pleased with the execution.

After a while, the flights of this owl into the woods became longer, and he only returned at dusk to receive his usual supper. By-and-by it was observed that he did not devour his meal in the kitchen as formerly, but fled along the passage, dragging the meat with him, till he reached the garden door, when he flew with it to a part of the shrubbery; on being followed, it was discovered that he had brought with him a companion who, not having courage to accompany him the whole way, remained at a respectful distance to receive his bounty. After having supplied his visitor in this manner, he returned to the kitchen and leisurely devoured his own portion. This practice was continued for some months, till at length one evening he was missed 
and nowhere to be found. His companion, it is said, continued to visit the spot alone for several weeks, uttering doleful cries, but could never be persuaded to come nearer to be fed. It proved in the end, that the favourite had been killed; and its stuffed skin was one day recognised in a woodman's hut, by the children who had so assiduously nurtured and brought it up.

Equally well known with the barn owl is the IVY, or TAWNY OWL (also called the wood owl), the familiar prowler of our woods and forests, whence it issues, at nightfall, in search of food, uttering its loud and melancholy hoot, and busily hunting for its prey. It is strictly nocturnal in its habits, seldom leaving its retreat during the day, but remaining ensconced in the hollow of an old tree, or amid the masses of ivy which cluster around the giants of the forest. The young broods are generally hatched in a hole of a tree, and are supplied by the parent birds with abundance of food; collections of rejected bones being not unfrequently found by the woodman, in these owl-nurseries, which have served the same purpose for successive years. The general colour of this species is tawny yellow, with dusky bars.

The owl is several times mentioned in Scripture, the whole tribe being doubtless included in the general term. It is always alluded to as em- 
blematic of solitude and mourning, and is classed among the "doleful creatures." Thus, the afflicted patriarch, bemoaning his sad and forlorn state, cries, "I am a companion to owls ;" and the psalmist in the day of his trouble bewails himself, "I am like a pelican of the wilderness : I am like an owl of the desert," Psalm cii. 6. It is striking to find in these incidental allusions such clear reference to the characteristic habits and tones of these creatures, and to see how in all ages they have been suggestive of similar ideas to the imagination and feelings of man. 


\section{ORDER II. INSESSORES.}

\section{PERCHING BIRDS.}

\section{CHAPTER I.}

The Shrikes, or Butcher-birds-Their singular mode of impaling their prey-The FLYCATCHERS-The Spotted Flycatcher or common Beam-bird-Two anecdotes, illustrative of the instinct and parental affection of this bird The Pied Flycatcher - The Thrushes - The Missel Thrush-The Song Thrush-Description of the manners of this bird-Friendship between two Thrushes - The Redwing and the Fieldfare-The Water Ousex, or Dipper-Description of this little bird, in its favourite haunts-The Riva Otsex.

THE second order is that of the PERCHING BIRDS. It includes a much greater number of species than any of the others, and the birds belonging to it are distinguished by their superior intelligence, and by the variety and excellence of their powers of song. This order is subdivided into tribes; the notch beaked, the full and strong beaked, the conical beaked, and the climbers.

The division that ranks nearest to the rapacious birds, and forms, as it were, the connecting link with them, is the sHRIKES; an interesting family, whose habits bear a strong resemblance to those of the 


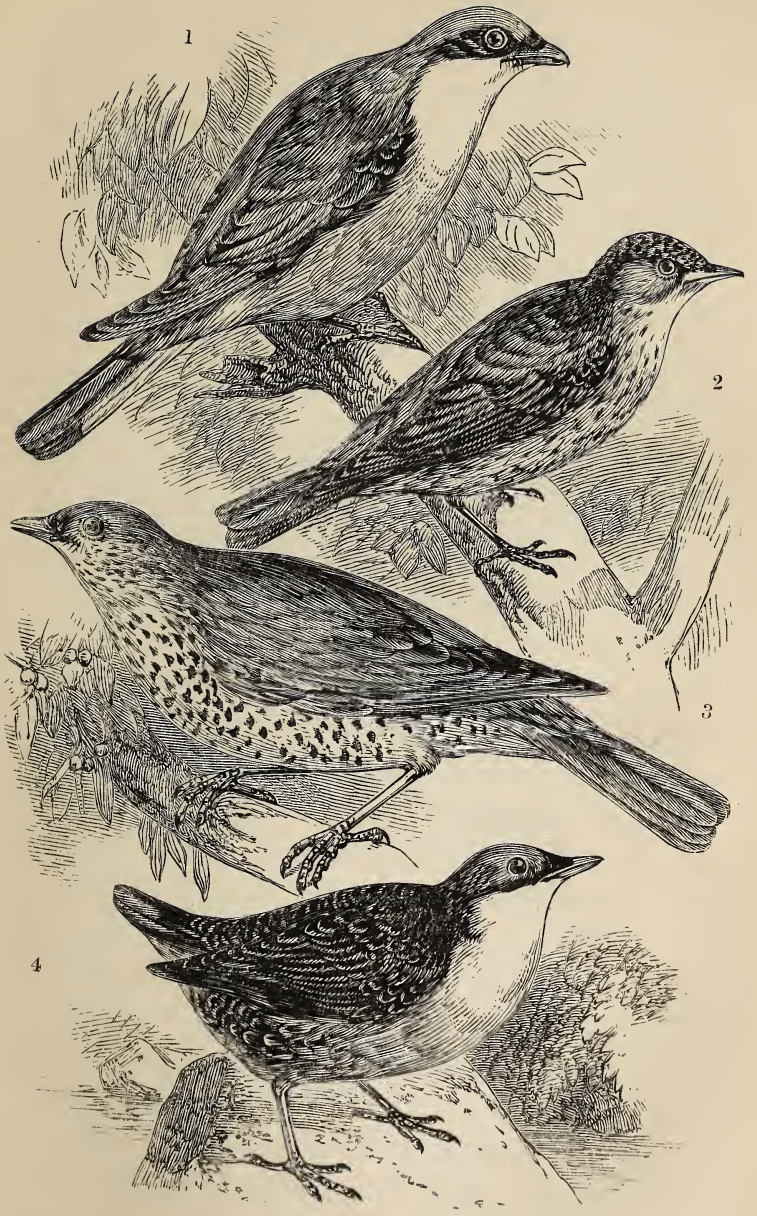

1. Red-backed Sirike.

3. Missel Thiuesh.

2. Shotted Flicatchers.

4. IVAter Ousel. 

birds of prey. The shrikes have been called the falcons of the insect world; pursuing and destroying as they do myriads of their tribes; and also butcher birds, because of the singular habit some of them liave of impaling the objects they have caught. Their usual food is insects; but they also devour small birds, mice, frogs, etc.; and they make use of the bill in killing their prey, which they tansfix on a thorn or pointed stick. One of the reasons for this very singular propensity seems to be the greater convenience it gives in tearing the flesh to pieces; for, if confined in a cage, they generally fasten their food to the wires before commencing the repast. It is supposed also, that as the quantity they destroy, especially of insects, far surpasses their need; they may be placed on the thorns as baits, to allure smaller birds.

The shrike has considerable power of voice, and is capable of such variation that it can imitate the notes of some of the little birds; which power it is said to use as a decoy. It is no wonder that the shrike should be an object of fear to his feebler neighbours, which manifest the utmost antipathy to his presence, mobbing, attacking, and driving him away, seeming perfectly aware of his plundering propensities.

There are three British species of this bird: the GREAT SHrike is uncommon, and the woonchat 
SHRIKE very rare. The RED-BACKED SHRIKE visits this country in summer, and is one of our latest birds of passage. Its young ones brought up from the nest, grow exceedingly tame, and make very engaging pets. The Rev. Mr. Lubbock, in his "Fauna of Norfolk," mentions this, and adds that a friend of his, who had given up falconry, amused himself by seeing his tame shrike catch flies, in the room he inhabited.

Of the FLYCATCHERS there are two British kindsone common, the other very rare. These birds are smaller than the shrikes, and their bills are less formidable, as their prey is softer, while their wings are longer, since they require to fly swiftly, in pursuit of insects, taken on the wing.

The SPOTTED FLYCATCHER (frequently called the* beam-bird), is one of our latest-but, at the same time, most regular, summer visitants. It frequents gardens, and often builds in holes of trees, upon the ends of beams, or on the branches of trees, nailed against walls. It is believed that the same pair of birds return to occupy the same spot, for several years in succession. They have no song, and merely make a chirping call-note. They act the part of hawks among flies, and are believed to live almost exclusively on winged insects. In the summer days, during those bright and sultry 
hours, when the flics are on the wing, these birds may be seen on the look-out for food; generally perched on some prominent twig, or on the top of a post or rail, from whence in an instant they dart, swift as a shot, on the approach of an insect, which is no sooner seen than caught, and apparently, with great ease, by a short.and rapid movement. With equal rapidity it is carried to the twig on which the bird was perched, and where he again keeps watch, as before. It is a very quiet little bird, as silent in its manner as it is sober in its plumage of ash-coloured brown.

A remarkable fact, exhibiting the instinctive sagacity of this bird, is related by T. A. Knight, Esq. :-A flycatcher built in his stove several successive years, and he observed that the bird quitted its eggs whenever the thermometer in his house was above $72^{\circ}$, and resumed her place on the nest again, when it sank below that temperature.

A still more striking story is told by Mr. White, who says, that a pair built every year in the vines that grew on the walls of his house at Selborne. One year they chanced to place the nest on a naked bough, and a hot sunny season coming on before the brood was half-fledged, the heat becane insupportable, and must have inevitably destroyed the tender young, had not the parent birds devised a mears to save them, by hovering over the nest 
during all the hotter hours, while with expanded wings and mouths gaping for breath, they screened off the heat from their suffering offspring.

The other, the PIED FLYCATCHER, is seen only in particular places, and is very rare. It is a bird of passage, and resembles the spotted in its habits.

The THRUSH TRIBE must next be mentioned. There are several species in England. The missel thrush, the fieldfare, the song thrush, the redwing, the blackbird, the water ousel (or dipper), and the ring ousel.

The Missel THRUSH (so called on account of its fondness for the mistletoe-berries), is one of the largest of his kind, and is the earliest song-bird of the year. His strain is something like that of the blackbird, and he has a singular manner of giving forth three distinct notes together, then pausing, and after a time repeating his triplet note. Hence he is sometimes called the thrice-cock, and as he frequently sings before, and during the time of wind and rain, he has also the name of storm-cock. $\mathrm{He}$ is a bold bird, vigilant in defence of his young, and when he utters his harsh note of alarm, it serves, like the bugle-call, to warn all the warblers of the grove that danger is near; and the chorus is silenced, until he again mounts to 
his favourite perch "on the topmost twig that looks up at the sky," and pours forth his glad song of deliverance.

The soNG (or garden) THRush, is a well known and general farourite. His song is by many considered one of the finest of all the melodies of the grove, and it is continued through almost every month of the year. This bird has also many recommendations - in his elegant shape, sprightly actions, and engaging ways. Every one is familiar with the manners of the thrush, and will recognise a life-like picture of him in the following description :-_" Grubs and worms are the principal food of nestling thrushes, quantities of which they may be seen collecting on lawns, particularly after showers have moistened the earth; and to an observer nothing can be more interesting than the way they and their associates, the blackbirds, set about it.

"Watch an old thrush pounce down on a lawn moistened with dew or rain. At first he stands motionless, apparently thinking of nothing at all ; his eye vacant, or with an unmeaning gaze. Suddenly, he cocks his ear on one side, makes a glancing sort of dart with his head and neck, gives, perhaps, one or two hops, and then stops, again listening attentively, and his eye glistening with animation. His beak almost touches the 
ground-he draws back his head, as if to make a determined peck. Again he pauses, listens, hops, perhaps once or twice, scarcely changing his position, and pecks smartly on the sod; then, is once more inotionless as a stuffed bird. But he knows well what he is about; for, after another moment's pause, after having ascertained that all is right, he pecks away with might and main, and soon draws out a worm, which his fine sense of hearing had informed him was not far off, and which his hops and previous peckings had attracted to the surface to escape the approach of what the poor worm perhaps thought might be his underground enemy, the mole."

Many amusing anecdotes are told of this bird. One must suffice here; it is mentioned by $\mathrm{Mr}$. Knapp, in his "Journal of a Naturalist." $\mathrm{He}$ says, "We observed this summer, two common thrushes, frequenting the shrubs on the green in our garden. There was an association and friendship between them that called our attention to their actions. One of them seemed ailing, or feeble from some accident; for though it hopped about it seemed unable to get enough food. Its companion, an active, sprightly bird, would frequently bring it worms or bruised snails, when they partook of tlie banquet together. The sickly bird would wait patiently, understand the actions. 
expect the assistance of the other, and come to meet it on its approach. This proceeding was continued for some days; but after a time we missed the foster-bird, which probably died, or by reason of its weakness met with some fatal accident."

T'hrushes and blackbirds are indefatigable destroyers of snails, which they hunt out from their winter rotreats under the hedges and walls, where they nestle by hundreds. So industriously is this search carried on, that the hedgerow is marked by a line of broken shells, as the birds bring them out from their holes, and batter the shells to pieces. The adroitness with which they break shells against a stone is well known. A favourite stone will occasionally be seen in a wood surrounded by the refuse shells, scattered around in greater or less quantities, for several feet. A tame thrush has been known to eat houseflies with avidity, and the earnestness which he exhibited while a person was feeding him with them was truly amusing.

The REDWING and FIELDFARE are but visitants here. The former is the smallest of the British thrushes. It considerably resembles the common thrush, and its notes are similar. It comes to our shores about September, arriving in flocks, and mingling, readily, with the fieldfare. Both these 
birds are natives of the northern regions, and while here, being in a foreign country, they have evident marks of keeping a kind of watch, to give notice of the approach of danger. The fieldfare comes shortly before old Michaelmas, and departs very early in May. Few birds are more regular in their time of arrival than these. It is indeed wonderful, when we consider the amazing distances birds have to travel, the accidents they are liable to meet; the adverse winds and rough weather they brave-how accurate are the times of their going and coming. It appears almost miraculous. If a table were kept, year by year, of their motions on these occasions, perhaps they would not be found to vary a fortnight in a hundred years, and yet what seas, rocks, and continents, have many of them to traverse! And so it has been from of old, even in the days when the prophet Jeremiah rebuked Israel for their want of consideration, teaching them wisdom by the birds; saying, "The stork in the heavens knoweth her appointed time; and the turtle, and the crane, and the swallow observe the time of their coming; but my people know not the judgment of the Lord."

That curious little bird, the WATER OUSEL, or dipper, is allied to the thrush and blackbird in many points; but it has also the habits and powers of the moor-hen, living constantly by the sides of 
rivers, swimming and diving with great facility, and feeding principally upon the various waterinsects which abound in those places where it haunts. It is chiefly found in the mountainous parts of England and Scotland, and in Wales it is resident here all the year round. The form of the dipper is rather "dumpy," but it has a sprightly look and manner, and is a very interesting bird. It catches part of its food standing on land, and part ás it floats on the water, but also a considerable part under the water, and to the water it retreats when threatened with danger on land. It walks into, or lights upon, the surface-rising, descending, or moving sideways, and apparently walking at the bottom of the stream. In fact, it appears to have almost as much command over itself there, as other birds have in the air. Its plumage is remarkably thick and close, like that of water-birds, and its feathers are supplied with oil, so that they do not become wet, even though it be a considerable time under the water.

This bird inhabits the most romantic situations, generally in the midst of fine scenery, and always among the rocks and banks of a rushing roaring torrent, or a clear bubbling mountain stream. The noise of the water hurrying over its rocky bed, is his sweetest music, and he can never be happy unless within reach of his native torrent 
He never leaves it; let it wind as it may, he follows its course, now up, now dowu, but always near the water; or he will sit in the middle of the brook, the water splashing around him, and sing his melodious little song, in the gladness of his heirt.

The RING OUSEL is also a regular British thrush, but it is not a common species. It is occasionally observed in small flocks in spring and autumn, on its passage to and from the regions where it breeds. 'The whole plumage is black, all the feathers edged with ash-grey. On the upper part of the breast is a large crescent-shaped stripe of pure white. The food selected by this species is similar to that of the blackbird-snails, insects, fruit, and hawberries, before the birds leave us for the winter, and ivy berries, when they return in the spring. Buffon says they feed largely on grapes in France, and are at that time delicious eating; he adds, that on account of their habit of placing their nests on or near the ground, they are sometimes called merles terres (ground thrushes). Their cry of alarm, when disturbed much, resernbles that of the blackbird.*

* There have been three other foreign species of thrush killed in England, White's thrUSH, the ROCK THRUSH, and the GOLD-VENTED TIIRUSH. 



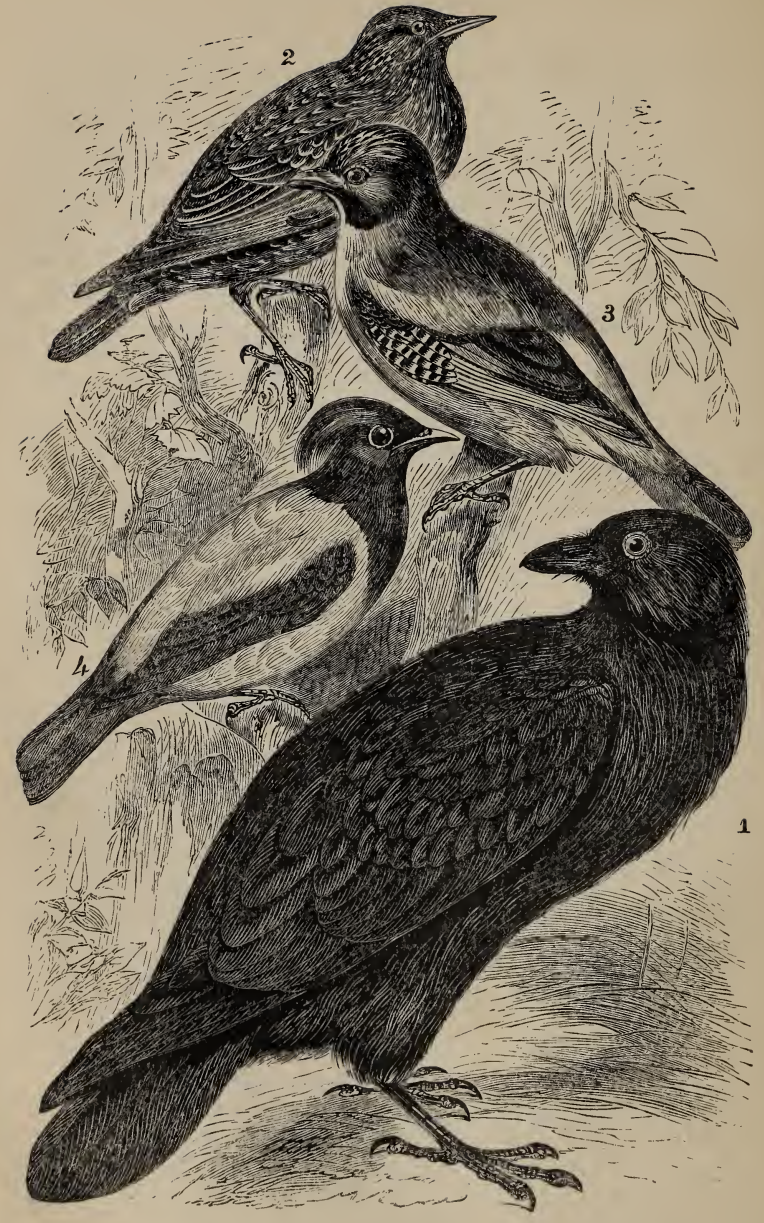

1. Raten. 2. Stailing. 3. Jay. 4. Rose-coloured Pastor. 


\section{PERCHING BIRDS.}

CHAPTER II.

The Pies and the Crows-The RAVEN-Superstitions about this bird-Account of a Roman Raven-Touching affection of a Raven for her young - "Taff," the tame ravenThe CRow and the Rook-Marked difference between these two birds-Enmity between them-Anecdote illustrative of this-Are Rooks friends or foes to the farmer? -Description of a Rookery-Anecdote of a colony of these birds-The Royston Crow-The Cнолgн-The $\mathrm{J}_{\triangle \mathrm{CKDAW}-C h a r a c t e r}$ of this bird-Curious account of Jackdaws stealing the flower labels in the Botanic Gardens at Cambridge.

ANOTHER distinct family of the perching birds, comprises the PIES, and the crows. The raven, the hooded, and carrion crows, the rook and the jackdaw, are names well known to us all; and included in the same tribe are the jay and the magpie.

The RAVEx, from his size and character, naturally takes the lead. He is to be seen in most parts of the world; and his ominous croak has got for him a world-wide fame. In days of ignorance and superstition, this sound was supposed to announce approaching calamity, and the changes of his notes were carefully studied by the artful 
soothsayers, who pretended to learn from them the secrets of futurity. The raven is a very hardy, crafty, and wary bird. It is exceedingly voracious, and seems to be a sort of glutton in its propensities, gorging itself with carrion, which it scents out with great readiness, probably having the sense of smell as well as of sight, in surprising perfection. This disposition renders it useful as a scavenger; but as it destroys young animals it is the detestation of the husbandman.

It is very easily domesticated, and, if pains be taken to teach it, can learn to do many amusing things. A raven, we are informed by the historian Pliny, that had been kept in the temple of Castor, flew down into the shop of a tailor, who was highly delighted with its visits, and taught the bird several tricks; and also to pronounce the names of the Emperor Tiberius and the royal family. The tailor was beginning to grow rich by the numbers of those who came to see this wonderful bird; till an envious neighbour, displeased at his success, killed the creature. The Romans took the poor tailor's part, punished the man who killed it; and gave to the raven all the honours of a magnificent interment.

The raven with us may be called the herald of the year. It makes its nest early in the spring; usually building on the top of some high tree, re- 
maining constant to the place once chosen, and continuing for a series of years to build there; the same faithful pair returning season after season, and rearing their young broods with the most persevering attachment. Though one of the shyest and most suspicious of birds, the raven has been known to die rather than forsake its post; and a very striking and well authenticated instance is given by $\mathrm{Mr}$. White, the naturalist of Selborne, who tells how the fond mother raven sat on her nest while the tree she had inhabited, time immemorial, was being felled by the woodman's axe; and how, when it gave way, the faithful bird was flung from her place and fell dead to the ground.

Numerous anecilotes of tame ravens are on record. In the "Zoologist," for 1851, the following is given:-"When out shooting a few days since, I observed an old man, apparently in conversation with some other person. On reaching him, I found he had been talking with Mr. Crother's raven, which was perched on an elm tree near him, keeping crows from a wheat-field. I called to the bird by name 'Taff,' and he immediately' answered 'Halloo!' in a very deep and hoarse tone. This was about a mile from the house. A few days after I heard that poor Taff would never keop crows again; having been killed by a grey- 
hound, while indulging his favourite propensity for biting the end of the dog's tail. At the same time I learned the following particulars of this remarkable bird. He was very tame, having his meals with the servants, and his dessert with his master, to whom he was much attached, sitting on his window-sill, as soon as it was light, until he arose, and accompanying him part of the way, if he went from lome; meeting him on his return, watching in a tree for hours; and as soon as he saw him again, flying and perching either on the horse's head or his master's shoulder. He took great delight in coursing; frequently turning a hare by his swoop. He was very mischievous; hiding things and thieving; and on one occasion he stole seventeen shillings; and the thief might never have been detected had he not been at length seen, flying with a shilling in his mouth. He had a great dislike to children, attacking them if they came near him. His roosting-place was a high tree, near the house, and he frequently alarmed persons passing underneath by some unearthly ejaculation."

From the raven we pass to the crow and the Rook; birds which are ignorantly considered, by many persons, to be one and the same. But this is a great mistake. The real crow, commonly called the carrion crow, more nearly resembles the 
raven ; living, like it, in pairs, and feeding on carrion, as well as on young fowls, rabbits and worms.

The rook, on the contrary, is a sociable bird; living in company with its fellows, and preferring a vegetable diet; or such grubs and insects as it finds.in the fields. There are other points of difference in the beaks of these birds. That of the rook is distinguished by the naked and scurfy white skin at its base; a peculiarity which naturalists are at a loss to account for. The plumage of the common crow differs, too, in colour from that of the rook, being of a greenish-blue; while the ronk's is more inclined to a rich purple.

Nor are these birds disposed to associate; on the contrary, the crows are regarded by the rooks as enemies, and the intrusion of a couple of carrion crows will suffice to drive them from their tenements. This was shown in a remarkable instance which occurred about two years ago, at Hatton Hall, in the neighbourhood of which a large colony of rooks had been established for some years. As usual, in the month of March, the rooks came, and began repairing their nests; stealing materials from those of their neighbours unless most sharply watched by their respective owners. When, all on a sudden, proceedings came to a stop, after some three or four nests were nearly completed, and several others begun. 
The rooks abandoned their purpose and retreated to a rookery at soine distance, where they settled and built. On examination, it was discovered that a couple of carrion crows had seized upon the rooks' domains, and thus summarily expelled them. At first the poor birds showed great reluctance to quit their loved homes, and when, once or twice, the crows disappeared for a short time, they ventured to return to their half-finished nests, from which, however, they were sure to be driven away by the return of their enemies; nor was it till after some time and many efforts that they finally yielded. Eventually the crows were shot, and within a very few days after the death of the last of them, a few pairs of rooks returned, and recommenced building their nests; but, where there were formerly fifty or sixty nests, only five or six are now to be seen; and probably somc time may pass before they will gain sufficient confidence to return in full force.

There is one question about which much difference of opinion has existed. Are rooks useful or injurions to the husbandman? Doubtless they are guilty of some pilfering. The great damage done by them is to newly-sown barley, which they dig up to feed their young with, as well as themselves; and when hard-pressed by hunger they will pillage the soft young potatoes and 
cabbages, and even attack the turnips. On the other hand, the amount of grubs and other enemies to the growing crops which they destrey, is really enormous. On the whole the verdict seems to be decidedly in their favour; and it is generally decided that "the rook must be reckoned among the farmer's best friends; and, in proportion as a knowledge of insect-foes increases, so much the more will he rise in our estimation." Independently, too, of the good services which these birds render, how pleasant is the regularity with which they carry on their movements to and fro, day by day; early in the morning wending their way to the fields, and at night returning in gathering flocks, with pleasant cawings, to their roosts; and their happy noises and busy flutterings as they tend their young in the nesting season, their early rising, their constant labour, and the order and police which they maintain at that time, are all very curious. The cawing and bustle begin at the greyest dawn, and most industrious is the man who can get to his work before the rook. "Ask the beasts, and they shall tell; the birds, and they shall instruct thee." It is good at this season to be near a rookery. There is no dozing; they will not allow you to "lose thought" in bed. You cannot sleep: you must rise, or suffer for it. But at night they disturb you not. "Early to bed 
and early to rise" is the rook's motto. The rooks seldom begin to build in good earnest before the first week in March. The whole business of nidification takes two months, of which about five weeks are taken up in building and hatching, and the remaining three devoted to feeding and rearing the young till able to leave the nest.

Bishop Stanley gives a very pleasing anecdote of these birds. It shows a power of discriminating individuals which is remarkable, and it also lets us into the secret of winning the affection of the lower animals. Clearly, they are sensitive to kindness, and capable of returning it. A farmer rented a farm in Essex, on which he had not long resided before a number of rooks came and built their nests upon the trees immediately surrounding the premises; and multiplied so rnuch in the course of three or four years as to form a considerable rookery, which he much prized. About this time, however, he was induced to take a larger farm; and this obliged him to change his residence and forsake his rooks. To his great surprise and pleasure the whole rookery manifested such an attachment towards him, as to desert their former habitation and to accompany him to his new abode, which was about threequarters of a mile off; and there they have continued to flourish ever since. It should be added 
that this person was strongly attached to all animals whatever, and that he constautly received a striking return of affection, even from the least docile of them.

A most extraordinary instance of personal attachment in one of these birds is recorded by Col. Maxwell in his "Wanderings in the Highlands." He seems to have had much experience of animal attachment, both in bird and beast, and, when a boy, had a raven which followed him about like a setter, was inconsolable when he went to school, and overjoyed on his return. But he declares that the most remarkable instance of feathered love for man, which ever came under his notice, was that of a common rook.

In a little village near Berwick there was a small public-liouse called 'The Ship,' the landlady of which one day saw some boys in the street torturing a poor rook, which they had tied by the leg to a stick, and were about to stone to death. She humanely interposed and saved the bird from the hands of its persecutors. "Jim Crow," for that was the name given him by his new protectors, soon became very tame, attaching himseif in a most surpassing degree to the landlord. He watched for his master in the morning and followed him through the day, was always at his elbow when he dined, and made himself 
very useful in gathering the scores during the convivial meetings which sometimes met in the evening at 'The Ship.' If there were a dozen persons present, Jim Crow would hop regularly round, omitting no one, and receiving the score from each respectively, pouch the money beneath his tongue, return to his master, insert his black and horny bill into the clenched hand of mine host, and honestly deposit there every coin he had collected.

It might have been imagined the poor bird could reason. The communication over the Tweed, between Spital and Berwick, is kept up by small steamers which cross the river repeatedly during the hour. If his master were missing, Jim Crow would fly down to the pier in order to ascertain if he were on board; and in that event the rook would cross the river, and, no matter where his owner went, he would be found flying by his side, or settled on his shoulder. It required no little ingenuity on the part of his master to blink this personal attendance of his devoted follower and companion. If he succeeded occasionally, by suddenly turning a corner or getting down an entry, the bird would fly up and down the street, look anxiously around, and if he could pop upon his lost proprietor his joy was unbounded, and, lest another separation should 
occur, he would stick to him for the remainder of the day, as closely as his own shadow. If, however, Mr. W. managed to get clear off, after a sharp search the baffled Jim would wing his way across the Tweed, return home, and there anxiously await the return of the runagate.

The first movement in the landlord's chamber of a morning-the first cough or creak of the shoe-which announced that his master was astir, was hailed by this singular bird with loud and exultant cawings. The landlord was a wag, and, sometimes opening his room-door, he would remonstrate with his noisy favourite, saying, "What are ye at, mon? Hauld ye're tongue, or ye'll wauken the bairns!" In a moment the loud and clamorous caw was exchanged to one so piano and subdued, that a skilful artiste could not have made the descending scale more rapidly and successfully. The arrival of the barber to perform his office was a signal for the temporary confinement of Jim Crow, as the bird always attacked furiously any person who he imagined was assailing his master, and, as if he knew that a razor was a dangerous instrument, he testified such enmity to the shaver that it was found necessary to secure him in another room while the barber was performing his office.

The end of poor Jim Crow was a tragical one. 
In an evil day he wandered from his usual domain, and settled down upon a garden fence in front of the shop of a tailor, who was stupid and cruel enough to kill the poor bird.

To return to the crow, which may be considered as a raven of small size, resembling it in all except its bulk. This bird is found throughout England, frequenting the sea-coast in some parts. In those places where large flocks of shecp are kept, it is a dangerous enemy, destroying weak lambs, as well as other small animals, game, and poultry. On the coast it picks the soft parts of dead fish, or eats such refuse as it can find. Like the raven and other birds of the family it conceals superfluous food. Col. Montagu observed two crows by the sea-shore, busy in removing small fish beyond the flux of the flowing tide, and depositing them just above high-water mark, when they had satisfied the cravings of hunger. The male feeds his mate while she remains on the nest, and both defend their young with great courage against birds much larger than themselves.

There is an intermediate link, seen in some parts of England, between the carrion crow and the rook, namely the HOODED, or ROYSTON CROW. This bird is said to be even more misclievous than the carrion. So destructive are they to young auimals, eggs, and poultry in the Orkney and 
Shetland islands, where they are numerous, that up to so late a period as 1835 , a reward of twopence a crow, was paid by the local authorities; in consequence of which many were annually destroyed. They are clever birds, and when frequenting the shore in search of fish, may frequently be seen, after vain attempts to break through the hard shell of a cockle or mussel, to seize it in their bill, mount with it to a great height, and then let it fall on a hard rock, by which means it is broken, and the bird has only to reap the benefit of his contrivance. Dr. Fleming, in his "Philosophy of Zoology" considers instinct, in this degree, as bordering closely upon intelligence, as implying a notion of power and also of cause and effect.

In the southern parts of England the hooded crow is only a winter visitor, but in the north it is resident throughout the year. On the first appearance of those birds in this country they frequent sea marshes, and the banks of tide rivers, inhabiting both sides of the Thames as high up as within a few miles of London, and when inland they visit the open downs and plains. The head, wings, and tail are a shiny bluish black, the rest of the plumage smoke grey.

Placed among the crows, but more nearly resembling the jackdaw and starling in manners 
and colour, is the RED-LEGGED CROW, or CHOUGH, never seen in most parts of our island, though in its favourite haunts often very abundant. It is almost exclusively confined to the sea-coast, where it inhabits the highest and most inaccessible portion of rocks or cliffs, about which it walks securely by means of its strong legs, toes, and claws. The plumage is uniformly black, glossed with blue, the beak and legs vermilion red, the claws shining black. It is easily distinguished from the true crows by the form of the beak, which is bent downwards.

At the southern end of the Isle of Man these birds build in security. In Cornwall, they are also found, and an old writer of the fifteenth century says the. Cornish chough was so great a favourite in those days, that some of the most ancient families bore these birds in their coat armour. But the locality assigned them by poetical authority is the celebrated cliff which now bears the name of the master-poet, Shakespeare; he says, in reference to its height-

"The crows and choughs that wing the midway air Show scarce so gross as beetles."

Like jackdaws, the choughs are easily tamed, and make amusing pets. Col. Montagu kept a bird some years in his garden. It was never 
observed to go upon the grass by choice, always preferring the gravel walks. Its habits are thus described by its owner.

"His curiosity is beyond bounds, and he never fails to examine anything new to him. If the gardener is pruning he examines the nail-box, carries off the nails, and scatters the shreds about. Should a ladder be left against the wall, he instantly mounts and goes all round the top of the wall; and, if hungry, descends at a convenient place, and immediately betakes himself to the kitchen window, at which he makes an incessant knocking till he is either fed or let in. If allowed to enter, his first endeavour is to get upstairs, and, if not interrupted, he goes as high as he can, and gets into the attic story; but his intention is to get upon the top of the house. He is excessively fond of being caressed, and would stand quietly an hour to be coaxed, but resents an affront with both bill and claws, and will hold on so fast by the latter that he is with difficulty disengaged. He is extraordinarily attached to one lady, upon the back of whose chair he will sit for hours; and is particularly fond of making one at a breakfast party, or, on a summer's evening, at the tea-table in the shrubbery. His natural food is, evidently, the smallest insects ; even the minute species he picks out of the crevices of the walls, 
and searches for them in summer with great diligence. Worms are wholly rejected; but flesh, raw or dressed, he eats greedily, and sometimes barley, with the pheasants, and other granivorous birds, occasionally turned into the gardens, and never refuses hemp-seed. He seldom attempts to hide the remainder of a meal. With a considerable degree of attachment he is naturally pugnacious, and resents an attempt to take him up, even by the hand that has just before fed and caressed him. To children he has an utter aversion, and will scarcely suffer them to enter the garden. Even strangers, of any age, are attacked vociferously, and he approaches all with daring impudence."

The JACkDAW is known to everybody. It is a gregarious bird, and frequently flocks together with rooks, feeding in the same way on grain and insects. It frequents old towers, ruined buildings, and high cliffs, where it builds, as well as in holes of trees; and it occasions great trouble to housewives in the country, by building down chimneys, which it frequently stops quite up, so as to fill the whole house with smoke, when an attempt is made to light the fire. It is active, noisy, and familiar almost to impudence, and lively, justifying the inquiry of some one, "Whoever saw a moping jackdaw ?" 
There is a curiousaccount, in Loudon's “ Magazine of Natural History," for 1833, of the habits of the jackdaws which at one time inhabited, somewhat numerously, the college buildings at Cambridge. In the Botanic Garden of that town there were wooden labels placed before the plants, whose names they bore, made of deal lathes, about nine inches long, and an inch or more broad. As they were thin, these labels, when dry, were pretty light, and the jackdaws speedily discovered that they might serve the same purpose as twiggy sticks off trees, and that they had the great convenience of being prepared ready for use, and placed very near home. Accordingly, they helped themselves freely, whenever they could do so unobserved; and they selected the early mornings, before the gardeners came to work, and occasionally would venture to perpetrate a theft during the working hours, when they observed the men occupied in a particular part of the garden away from the flower-beds. They also took advantage of the hours for meals, when the coast was left free to them. Their mode of proceeding was thus: the bird would grasp a label edgewise in its beak, and draw it out of the soil. Usually this was accomplished without much trouble; but, when more deeply infixed, it would pull the label first to one side then to the other, until it 
succeeded, or would become weary, and leave it. It next proceeded to balance the label in its bill, letting it fall and picking it up again, until it had ascertained the place at which it could be held in equilibrium, when it flew off with it. The number of labels thus annually removed is supposed to have been very considerable, persons who had ascended the tower of Great St. Mary's church, and other towers and steeples, having repeatedly observed wooden labels bearing botanical inscriptions, in great uumbers lying about in these places. A chimney in one of the professor's louses having been stopped up, the jackdaws built in the upper part of it, and the man-servant, on one occasion, actually took eighteen dozen of the said deal labels from the chimney-shaft. 


\section{PERCHING BIRDS.}

CHAPTER III.

THE $J_{A Y}-$ Its powers of imitation-The sportsman and the jays-The jay and the cat and kittens - The MAGPIE-Its sagacity-Superstitions respecting this bird-Two anecdotes of tame magpies-The nest of the magpie-The STARLING-Congregates in large numbers-Account of a flock of starlings-Starlings, rooks, and jackdaws very friendly-The ROSE-COLOURED PASTOR-Its beauty and habits.

ThE JAY is a beautiful bird; but though showy to the eye, it is more frequently heard than seen, for it is very shy and cautious. It frequents groves, plantations, and woods; and even in its native state, is much given to imitation; being very adroit at bleating, screaming, and neighing; in short, mocking all the harsher sounds. Its own common note is harsh and unpleasant, but its love-song is very soft, and is so low, and apparently cautious, that it seems whispering to its mate, as if to keep their affection and cares secret from the other tenants of the grove. It is rarely seen in the open country, except when its favourite fruit, the cherries, are ripe. The chief food of the jay is the acorn ; but it also eats other birds' eggs 
in spring, as do all the crows, jays, and magpies, to some extent.

Young jays are easily brought up from the nest, and soon become very tame. In confinement they appear to prefer meat to any other kind of food. They are very amusing, from the ease with which they imitate almost any sound they are accustomed to hear. These imitations are so exact as to deceive not only men but animals. I was once visiting in a house where there was a jay, who entertained us highly with the tricks he played on an unfortunate cat with a litter of young kittens. No sooner had poor puss, after performing her maternal auties, left her charge and retired for a short time to rest and refresh herself, than the mischievous jay would commence a piteous outcry, in exact imitation of the cries of a family of kittens, in the last extremity of distress. In a few seconds, the anxious mother would rush in from the garden, or bolt down the stairs, from some upper room, full of eager alarm. On reaching the basket, and finding her progeny sleeping in sweet security, she would turn round, with an air of vexation, and retire slowly; the jay, with his head knowingly set sideways, and his eye keenly watching her, probably meditating a renewal of the fun so soon as occasion should serve. 
A curious incident once happened to a sportsman, who, going into a copse to shoot ring-doves, and seeing something high up on a branch, fired; when down fell a lump, apparently of old rags, which proved to be a number of jays. As soon as they touched the ground, none being mortally wounded, the cluster separated, each bird flying away in a different direction, with most vociferous chatterings. The weather was very severe, and they had evidently huddled together, in that odd way for warmth.

Like the jay, the MAGPIE is a clever and shy bird; very keen to perceive danger, and very acute in shunning it. It is quite proverbial how magpies and jays know Sunday from week-days, and will allow any one to come much nearer to them on that day, evidently feeling secure. This fact is noticed by a writer in "The Zoologist, for 1851." He says :- "Where I reside (Stroud) the jays visit my shrubberies, and when I go there on a week-day, they immediately give out their note of alarm-'skay, skay !'-but, strange to say, on several Sundays, I have approached them at a quarter of the distance, and they would fly out without any cry of alarm."

The magpie is a great enemy to young blackbirds, and also destroys eggs of all sorts, which propensities have procured it a bad name; and, in 
this country, it is doomed to destruction by every one who carries a gun. But for its sagacity, which is eminently evinced in its self-preservation, it would be a rare bird. It has certain habits which have attracted the attention of the ignorant and superstitious, who look on it as a bird of ill-omen, prognosticating by its appearance the approach of death. It is, in fact, one of the most susceptible of the feathered tribes, and, if carefully watched, would be found an excellent guide as to weather, and might be consulted with advantage touching the heat, the moisture, and the general state of the atmosphere.

Mr. Yarrell says the magpie did not formerly exist in Ireland, and that it was only in the reign of Queen Anne that the bird began to spread generally over the kingdom-that is, at the same time as the introduction of frogs; and these creatures are sometimes spoken of traditionally as having made their appearance together. Now, there is no part of the world in which they both thrive better than in Ireland. In France, the magpie is one of the few birds that nobody seems to molest, and it is, accordingly, very common there. It is also regarded with peculiar favour both in Norway and Sweden.

There are many pleasing stories told of these birds. The two following are of recent date:- 
A favourite magpie had been accustomed to receive dainty bits from the mouth of its mistress. One day it perched as usual upon her shoulder, and inserted its beak between her lips, not, as it proved, to receive, but (as one good turn deserves another) the grateful bird dropped an immense green fat caterpillar into the lady's mouth.

The sagacity often exhibited by them, when tamed, is very surprising. A favourite magpie was in the habit of occasionally hiding any food he did not immediately want in some long grass, at the bottom of a row of iron hurdles. This hoard was discovered, and often robbed, by a favourite terrier. One morning mag was observed in great excitement, hopping and chattering incessantly, rapidly repeating every. word in his vocabulary at the dog, who was busily engaged in rifling the store-house. In his search, however, he passed over a tuft of grass, in which a piece of beef was concealed; mag was at the spot in an instant, drew forth the treasure, and securely fixed it on the highest bar of the hurdles, far above the dog's reach. He then, at a little distance, began pluming his feathers, chattering to himself, with a very self-satisfied air, and occasionally hopping back to take another look at his recovered meal; evidently priding himself on his skill.

The nest of the magpie deserves notice. It is 
well constructed for defence against enemies ; being: of an oval shape, and large; framed on the outside with sharp, thorny sticks, strongly interwoven, and forming a dome over the top. This framework is plastered inside with earth, and lined with fibrous roots and dry grass. One small opening is left at the side, just enough to admit the parent bird, which generally sits with her head to the hole, ready to escape from the nest at the slightest alarm.

Few birds are more generally known than the STARLING; and as it is a familiar bird, and easily tamed, its habits, in a state of captivity, have been frequently observed. The evening is the time when starlings flock together in greatest number, and betake themselves to the fens and marshes, where they roost among the reeds, to which they resort in such numbers as to break down and destroy whole beds. They chatter most vociferuusly in the evening and in the morning, when they assemble and disperse.

A striking account of the numbers in which they are sometimes seen, is given in "The Zoologist, for 1849." The writer says :- "On October 2nd, 1844, I noticed the most amazing flock of birds that it was ever my lot to witness. They were starlings. At a distance they resembled some gigantic mass of cloud, slowly traversing 
the heavens, and occasionally changing its form, and breaking into smaller masses. It was evening, and the birds had, probably, collected together to roost for the night, in a large wood, over the top of which they were enjoying a few moments, before retiring to rest. The ease and elegance of their movements, as they flew to and fro; the firm and compact manner in which they kept together when moving in mass; the peculiar facility which enabled them to break the main army into num- berless smaller ones, and then unite again, almost instantaneously, was perfectly astonishing, and equal to anything ever witnessed in the flight of birds." Mr. Jesse observes that, when a flock of starlings is seen from a distance, with the sun reflected on their wings, they appear and disappear as they turn to the left or right, according to the gleams of light.

Starlings keep up a close and friendly intercourse with rooks and jack-daws; but, on looking at them in the fields, it will be perceived, that while the two latter mix promiscuously, both in their movements and in searching for food, the starlings always keep to their own flock. This is a secret in the habits of birds which the naturalist cannot fathom. These are, at all times, very lively birds; and at pairing time, when others fight, they are all play and good humour. They not only 
associate with other birds, but imitate their cries ; chattering with jack-daws, whistling with plovers, and screaming with sea-fowl.

Very nearly allied to the starling is the ROSECOLOURED PASTOR, one of the handsomest of our occasional British birds. Though only an accidental visitor to this country, its beauty attracts particular notice, and its capture is more regularly recorded than that of many other equally rare birds. The colours of the plumage, in the male bird, are violet-black, on the head and neck; the feathers on the crown of the head being elongated, so as to form a flowing crest. The back, breast, and belly, are of a delicate rose-colour. This bird flies, like the starling, in flocks, and in other habits and peculiarities also resembles that species. It feeds about among flocks and herds, (whence it was probably called Pastor; $i$. $e$. shepherd, or herdsman), and frequently mounts on the back of sheep and cattle, in search of the grubs which are found there. Insects appear to form a principal part of its food, but it also is fond of fruit, and has been often seen in gardens. 


\section{PERCHING BIRDS.}

\section{CHAPTER IV.}

The WARBLers-Our choicest song-birds' nests-The Pied and the Yellow Wagtail-Account of these birds kept in an aviary - Anecdote of a Water-Wagtail nestling in a workshop-The Wrens-The Redbreast-Description of this bird and its nest-Anecdote of a Robin and an Angora cat-Curious nesting-places of the Redbreast-The common Wren-The Golden-crested Wren, and the Firecrested Wren-The Nightingale-Its exceeding shynessIts song and migrations-Isaac Walton on the Nightingale.

The various divisions of the PERCHING BIRDS are, at present, but imperfectly arranged; few authors agreeing in the formation of the minor groups. A few of the principal characteristics, and sorne anecdotes descriptive of the manners and habits of some of the most familiarly-known species, may perhaps be best adapted to the wants of the young student.

The WARBLERs are a numerous race. They are the choicest of our summer birds of song, whose voices resound through the groves and woodlands of our happy country, reminding us of the Psalmist's description of the springs and valleys where "the fowls of heaven have their habitation, which sing among the branches," and "the birds 
make their nests." * The Psalmist was an accurate observer. It is, undoubtedly, in the season of reproduction, when the birds are busy with their nests and young broods that their melodious songs are heard, "amid the branches ;" then it is that,

"Our isle is full of pleasant noises, Sounds, and sweet airs, that give delight."

About ten weeks have been mentioned as the period during which most of our wild birds sing. Few spots are more musical with song-birds than these islands. Not, indeed, that the woods of America are mute; but they have not the varied brilliancy of our choristers.

It is among the perching birds that our songsters abound ; and they, too, excel in the beautiful structure of their nests. Great as is the skill of insects in architecture, it attains, if possible, a higher degree of perfection in birds, the great majority of which build the most artistical nests, selecting situations according to their habits, either on the ground, in shrubs, or trees, or on rocks and buildings. It is a received opinion with many, that the more perfect the nature of the bird the higher from the ground is the nest constructed; but this rule will certainly not apply to the powers of melody; since the nightingale and the lark build either on, or near to, the ground.

Psa. civ. 


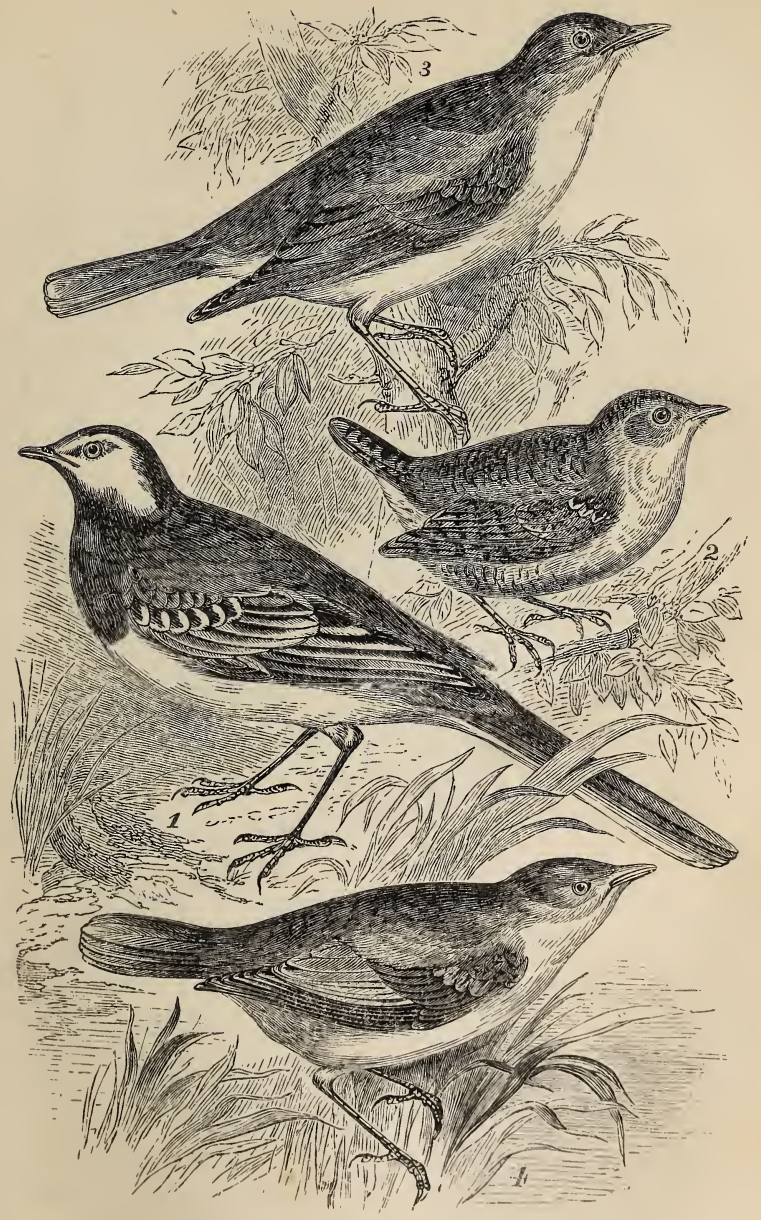

1. Pied Wagtail. 2. Wren. 3. Nightingale. 4. Reed Wren. 

Where all are wonderful, it seems almost invidious to select examples; but I will mention the nests of two of our native birds-the LONGTAILED TITMOUSE and the SWALLOw.

The former builds a singularly curious and elegant nest, of a long oval form, with a small hole in the side, near the top, as an entrance; the outside is formed of moss, woven or matted together with the silken shrouds or cocoons of insects, and covered all over with the tree and stone lichens, fixed with fine threads of the same silken material. From this thatch the rain trickles off without penetrating, while, from its similarity in colour and appearance to the bark of the branch, or the foliage of the shrub on which it is placed, it is not easily discovered. The inside is thickly lined with a profusion of feathers, the soft webs of which are laid inwards, with the quills or points stuck into the outside fabric.

As for the swaLLow, its mode of operation is entirely dissimilar from all others. The crust, or shell of its nest seems to be formed of such mud or loam as comes most readily to hand, tempered and wrought together with little bits of broken straws, to render it tough and tenacious; and that the work may not, while it is soft and yielding, pull itself down by its own weight, the bird has prudence and judgment enough not to advance 
its construction too fast. About half-an-inch seems to be a sufficient layer for a.day; and thus, in about ten or eleven days, a hemispheric, or globelike nest is formed, with a small aperture towards the top; compact and warm, and perfectly adapted to its purposes. The crust or shell, is a sort of rustic work, full of nobs and protuberances on the outside; but the inside is smoothed with more care, and, in some instances, has even a glazed appearance.*

A volume might be filled on the subject of birds' nests, they are so wonderful. The following pretty lines by Mr. Pennant, will please the reader.

"Behold a bird's nest, Mark it well, within, without.

No tool had he that wrought; no knife to cut,

No nail to fix, no bodkin to insert,

No glue to join; his little beak was all.

And yet how nicely finish'd! What neat hand

With every implement and means of art

Could compass such another?"

It is certainly, in the construction of their nests that birds display the most striking and varied indications of contrivance; and often they have recourse to means which would do credit to a reasoning being. A pair of goldfinches had built their nest on a small branch of an olive-tree.

* Thompson. 
After hatching the brood, the parents perceived that the weight of the growing family would soon be too great for the strength of the branch which supported the nest; in fact, it was beginning to give way. Something must be done, or the nest would fall. This was evident to beholders, and equally so to the goldfinches; accordingly, they were seen to fasten, by a small string they had picked up, the bending twig to a higher and stronger branch of the tree, and, by this contrivance their nest was saved.

Some birds, * which use the same nest for a succession of years, regularly repair them, carrying up sticks and sods, etc., for the purpose of enabling them to stand the violence of the winter storms; a mode of proceeding which appears to indicate a remarkable degree of forethought or prospective contrivance.

Among the warblers may be ranked the wagtails, the wrens, the chats, and the pipits. Of the true warblers, the well-known prince is the nightingale.

The WAGTAILS get their name from the remarkable rapid, and almost incessant, motion of their tails. These birds all either leave this country in winter, or remove to different places in it. * e.g. Rooks and the Fishing Hawk of America, etc. 
They frequent the margins of waters, clear springs and pools, in retired places, and they build their nests mostly under stones or in holes near the banks, and feed chiefly on aquatic insects and worms. They move with alacrity and glee, every now and then dipping the head, and anon recovering their balance by the peculiar motion of the tail. There are four British species, of which the PIED and the YELLOW WAGTAIL are the most common. The former, with its variegated plumage of black and white, is deservedly admired for its elegance, activity, and airy lightness, and is exceedingly common over the whole of the United Kingdom, being resident in the southern parts, throughout the year. A gentleman who kept a variety of these birds, in a large aviary, writing to Mr. Yarrell, says, "During the summer and autumn of 1837, I had several wagtails; the pied and the yellow, both of which were very expert in catching and feeding on minnows, which were in a fountain in the centre of the aviary. 'The birds hover over the water, and as they skim the surface, catch the minnow when it approaches to the top of the water in the most dexterous manner. I was much surprised at the wariness and cunning of some blackbirds and thrushes in watching the wagtails thus engaged, and immediately seizing the prize for their. own dinner." 
A curious anecdote is told in "Jesse"s Gleanings of Natural History," of a water-wagtail, which built her nest in the workshop of a manufactory, within a foot of the wheel of a lathe, in the midst of the din of hammers and workmen. There unmolested, and unconcerned, she hatched four young ones. The cock-bird, not seeming to approve such company, instead of feeding the nestlings himself, as is usual, carried the food he had collected to a certain spot on the roof, where he left it for the mother to convey to her young. It is remarkable that she was quite familiar with the men who regularly worked in the shop, but would instantly quit her nest if a stranger came into the room, or, if away, would not return till he was gone, when she lost no time in resuming her place.

In the family of wRENs we may include the redbreast, the common wren, and the golden and firecrested wrens. It is not a little remarkable that there is more similarity between the common wren and the redbreast, than between it and the birds commonly called wrens. So much so, indeed, that the popular opinion (which in these cases is usually founded upon observation,) has, time out of mind, associated robin redbreast and kitty wren as husband and wife.

The REDBREAST is, however, more really a 
warbler than the wren, and connects the warblers with the chats. This well-known favourite associates more familiarly than almost any other bird with men; yet it is, really, a native of the woods. It is unnecessary to describe a bird so universally known. Not only is it a most entertaining little creature, but it is also exceedingly useful, capturing myriads of insects and worms, and destroying the eggs of flies and caterpillars. The manner of approaching its prey, when on the ground, is by very light and rapid hops; and when the bird has got within its distance, it pounces upon the object with great certainty.

The song of the robin is sweet and plaintive; but not very powerful. It is said that the different changes of its strain indicate the varying states of the weather; and that, when the bird perches high, and sings cheerfully, it is an unerring promise of fine weather. The sprightly manner, full dark eye, and sidelong turn of the head in this bird give it an air of sagacity and inquisitiveness, which, together with its confidence, has gained it friends. With many redeeming qualities, however, the robin is one of the most pugnacious of birds, and maintains his right to his own "beat" against all intruders. The nest is frequently placed on a bank, in a hole of a wall, or by the roots of trees, and in concealed 
places. If there be not a natural concealment of foliage the birds contrive to form an artificial one of dry leaves; and when the female leaves her eggs, she sometimes covers them in the same manner; so that the strewing of leaves, mentioned in the old ballad of "Babes in the Wood," is true to the habits of the robin.

These birds show great attachment to their young, and are bold in their efforts to thwart any intruder on their nest. An instance has presented itself to my notice while I am writing these pages. ()ur garden robin has evidently chosen for his nesting-place a thick clump of ivy, that hangs over the wall, and partly covers the roof of an out house. The other morning my attention was arrested by a loud wailing cry, accompanied with angry twitterings, which was recognised as the voice of robin in distress. On looking out of the window the cause of his trouble was soon discovered; for, on the roof, basking in the sun, lay our splendid Angora cat, within a very short distance of the clump of ivy. On the edge of the roof was the agonized bird, twittering, hopping, and incessantly jerking his body up and down, with earnest haste, as though panting with eagerness, and about to pounce upon the cat, whom he continued to mob; and, by degrees, emboldened by the utter nonchalance of his enemy, he hopped 
nearer and nearer, till within an arm's reach of the foe, still continuing his clamorous outcry. This curious scene lasted for an hour or more, till at length puss, disliking the noise, or tired of roasting himself on the hot tiles, retreated in-doors, leaving the poor little courageous bird at peace.

Like some other birds, the redbreast is remarkable for the peculiarity of the places in which it sometimes builds its nest; often within the habitations of man. A window curtain, a book-shelf, a cornice, a reading-desk, have all been chosen by our confiding little friend, and even a child's covered-cart. In all these instances the birds reared, tended, and brought off their broods, quite regardless of the presence of persons in the rooms into which they had intruded.

The common wren, is abundant in all parts of the country, remaining with us the whole year. Considering the diminutive size of the bird, its song is clear and loud, so that one is surprised at its proceeding from so tiny a musician. It is very small, and its form is short and dumpy. It carries its tail,-which, though short, is very strong for the size of the bird,--in a nearly erect posture. That structure of tail enables it to balance itself, so that it can drop down (its most important motion) with great agility. Among our small birds there is scarcely one better known or more 
privileged than the little wren, frequenting gardens close to our houses, and creeping, mouse-like, through hedges and underwood. The numerous progeny of the wren is proverbial,--and it brings off two broods in the season.

The GOLDEN-CRESTED WREN, is the smallest of British birds; but it is one of the most active, and endures the winter better than many larger birds. It is found in all wooded parts of the country ; fir woods, however, are its favourite haunts. Both this and the FIRE-CRESTED WREN, which nearly resembles it, and which is only a very accidental visitor to Great Britain, are so minute, that, hidden as they are among the branches, and shifting and whisking about with meteor-like rapidity, it is no easy matter to see them. The best way to study them is by the aid of a small pocket-telescope, which no one who observes the smaller birds should be without, as they can thus be watched without alarm or disturbance. The young naturalist, when he goes to the wood or coppice, should be thus furnished; there is ample room for fresh discoveries; and observations perseveringly and accurately taken will be sure not to go without reward.

Of all the warblers the nightingale bears, beyond dispute, the pre-eminence. It is acknowledged to possess, in a higher degree than any 
other of our British birds the necessary requisites of a first-rate songster: its voice being unrivalled in volume, quality, and execution. With its music we are all acquainted; but its habits are so concealed, its disposition so retiring, that it is very little we can learn about it in a state of nature. An accurate observer says, "I watched them very carefully for more than five years, in a place where these birds are very abundant; and at the end of that time I was about as wise as at the beginning."

The nightingale is first heard about the middle or end of April ; its song continues till the first or second week in June. The birds taken in the county of Surrey are said to possess the finest quality of song. Its favourite haunts are woods, plantations, and hedgerows. In the midland counties it is scarce; in the northern, but occasionally heard; and in the western, namely, Devonshire and Cornwall, almost unknown. It is not found at all in the north of Great Britain, although it visits the more temperate parts of Russia, and some parts of Siberia. The migration of nightingales, like all other regular migrations, is from north to south in autumn, and back again in spring; an English nightingale would, probably, go to Morocco; a Russian nightingale to Egypt.

That ardent lover of nature Isaac Walton has 
said, "He that at midnight, when the very labourer sleeps securely, should hear, as I have very often done, the clear airs, the sweet descants, the natural rising and falling, the doubling and redoubling of its voice, might well be lifted above the earth, and say, 'Lord, what music hast thou provided for the saints in heaven, when thou affordest bad men such music on earth.?" 


\section{PERCHING BIRDS.}

\section{CHAPTER V.}

The True Warblers. The Two most common of these birds, the Sedge Warbler, and the Reed Warbler-THE SYLVAN WARBLERS-The Redstart-The Common Whitethroat-Anecdote of the Whitethroat and the Nightingale - The Blackcap Warbler-Beauty of its song-The tame Blackcap-The Greater Pettychaps, or Garden WarblerThe Lesser Pettychaps, or Chiffchaff-The smallest of its kind-The tame Chiffchaff-The Wood Warbler, and the Willow-Warbler.

OF those interesting little birds the TRUE WARBLERS there are several species, more or less common. They are different in appearance, according to the haunts in which they are found, but there seems a general likeness among them. They are delicate in form and plumage; and subdued rather than strongly marked in colouring. Their whole expression is soft, but not dull; and their manners, though gentle, are rather sprightly. Though they are not all song-birds, they comprise the finest of our songsters, and their notes run more on the minor keys than those of any other birds.

All the warblers love shade and shelter; some in the grove, others in the coppice; and some by the reedy pool. But they are less found in the wide waste of the forest. They are summer so- 


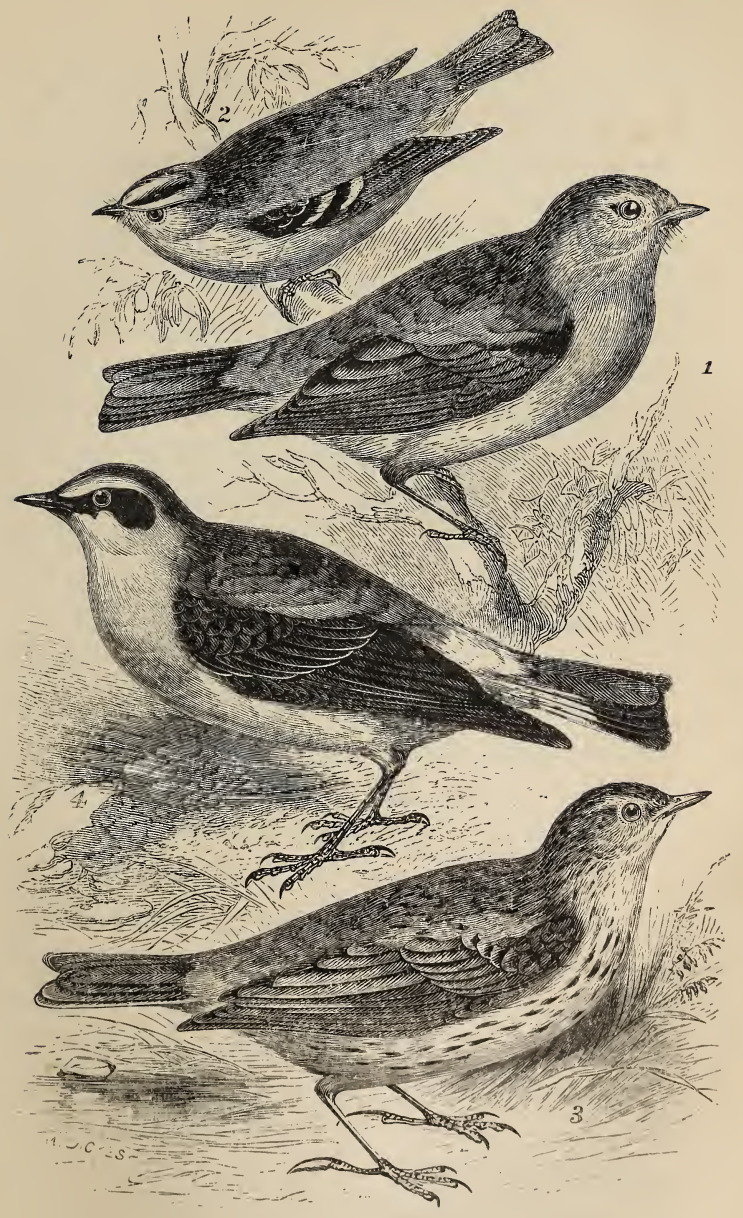

1. Redrreast. 2. Gold Crest. 3. Meadow Pipit. 4. Wheatear. 

journers, coming from afar, having left us during the winter, driven away by the inclemency of our skies, and returning in the genial season to cheer us with their songs.

Among them, there are four British aquatic species. The two commonest are the SEDGE and the REED WARBLER. Of these the reed warbler, or reed wren, is well known, with its elegant and singularly-built nest, interwoven among the reeds, and fastened to their flexible twigs ; and so well-united and firmly fixed, that it can bear to be rocked upon its bending supports.

Of the SYLVAN WARBLERS, there are about ten or eleven. Besides the nightingale, already mentioned, which stands first, the redstart, the common and lesser whitethroat, the blackcap, the garden warbler and chiff-chaff, and the wood and willow warblers, are the principal; and there are, moreover, two or three rare kinds.

'The REDSTART is common in most parts of the kingdom, and frequents gardens and woods. It has a way of rapidly expanding and closing the tail, and this action is continued for several seconds, on its alighting. It is an elegant little creature, with its black, white, gray and flame colours, and its graceful form and lively motions, It bears a slight general resemblance to the red- 
breast, but it is longer in the body, and much more slender. Its favourite resting-places are deserted walls and old houses, and ruins, covered with ivy. Its song is sweet and plaintive, something like that of the nightingale, supposing it to be given in music-box style. It is, also, an imitator of the notes of other birds. T.e food of the redstart is insects. It arrives here in April, and leaves towards the end of September.

The common whitethroat is the best known, most numerous, and most generally distributed of the warblers. It comes about the third week in April, and frequents the sides of woods, thickets, hedgerows, and grassy lanes; particularly when overgrown with weeds and brambles. Hence it is sometimes called the nettle creeper. These birds are active and shy, and easily alarmed, immediately retreating beneath the cover of the tangled masses of foliage they haunt. Their food consists of insects, in their various states, particularly white caterpillars, and of the smaller fruits and berries, in search of which they visit kitchen gardens. Some of the notes of the whitethroat are rather harsh, others pleasing, but he always sings in good earnest, erecting his crest, puffing out his throat, and jerking his tail, with much animation. Occasionally, he sings on the wing, ascending in small circles and then returning to 
the spot whence he arose. In confinement these birds are lively, and easily managed. Mr. Sweet says, that one he possessed would sing for hours together, against a nightingale, and would not suffer itself to be outdone. When the nightingale raised its voice, he did the same, and tried his utmost to get above it. Sometimes, in the midst of the song, he would run up to the nightingale, and stretch out his neck, and whistle as loud as he could, staring it in the face; and if the nightingale attempted to peck him, away he went in a moment, flying round the aviary, and singing all the time.

The BLACKCAP WARBLER is a common and widely dispersed species, visiting this country about the same time as the nightingale. The males, which are readily distinguished by their jet-black heads, arrive, as is usual with many birds, (especially of this family, ) some days before the females, and their song soon betrays their retreat. They frequent gardens, plantations, and thick hedges, and are restless and shy, concealing themselves from observation. The blackcap is considered to be second only to the nightingale in his song; and his tones are deep, sweet, and full. The song is generally given from a high perch or branch, and while singing, the bird raises his head and inflates his throat, appearing in a high state of 
excitement. In trilling, it especially excels, surpassing every other songster of the grove in the rapidity and clearness of the swells and cadences which it gives to the same trill. It has a wildness and witchery in its strain, that seems to partake of the nature of genius. Occasionally it adopts the notes of other birds, but transposes them into a lower, or minor key; finishing them off with a sort of wild variation of its own. The nest is near the ground, generally in a bush; and the male takes his turn in sitting on the eggs, and, seemingly, is so delighted with his task, that he frequently sings while sitting; thus leading, not unseldom, to the discovery of the carefully concealed nest. The food of these birds is insects and caterpillars, and when the supply of them is exhausted, it takes to the fruit, especially raspberries and red currants. Bechstein says that a young male bird which he kept during the winter in his hot-house, being accustomed to receive a meal-worm whenever he entered, became so accustomed to this, that when he saw him come, he immediately flew to the jar where the worms were kept, and, in case the signal was not attended to, he would fly, and pass close under his master's nose, and then resume his post; this he repeated, sometimes even striking his wings against him, until his wishes and impatience were gratified. 
The GREATER PETtYchaps, or garden warbler, is not uncommon in many parts of the country. It makes its appearance early in May, haunting gardens and hedges. Its song resembles that of the blackcap, but is less powerful. It ranks next in esteem as a songster, and its rich soft tones resemble exquisite flute notes. The whistling part of the stave, which has something of the mellowness of the blackbird, has an unbroken swell, which is at once characteristic and peculiar. It is larger then the blackcap, and has longer wings. Unlike that bird, it does not sing from a high perch but from the close cover, hence it is not often seen, even by those who search for it.

The LESSER PETTYCHAPS, or chiff-chaff, is the smallest of our warblers, and the most hardy, coming as early as March, and remaining till Oetober, and occasionally in mild winters remaining a straggler in the warmer districts of the country. It is very abundant in some parts of England, and is found further north than any other of its kind. It frequents woods and tall trees, and is very restless in its habits, being always on the search for insects. Its song consists of but two rather loud hollow notes, resembling the words chip-chap, or chiff-chaff. Mr. Sweet says, this bird is easily taken in a trap, and soon becomes tame in confinement. One that he caught was so familiar 
as to take a fly from his fingers. It also learned to drink milk out of a teaspoon, and was so fond of it, that it would fly all round the room after it; it would also dart up to the ceiling, and bring a fly down every time.

The HEDGE WARBLER, better known to us by the name of hedge sparrow, is so general everywhere throughout the British Islands, that it comes under the observation of all. It frequents hedgerows and gardens, from spring to autumn, feeding on insects, worms and seeds, but not on fruits. Early in February the short and sweet, though rather monotonous, song of the male is heard; and continues throughout the greater part of the year. The nest is usually placed, rather low down, in a thick hedge or bush, and is the ready booty of every prying boy; so that the blue eggs of the hedge sparrow may be seen strung in long rows in every cottage collection. They are sociable and harmless little birds, and in winter come near to our habitations in hope of some chance supplies, which their gentle and unobtrusive manners fully entitle them to receive at our hands.

The WOOD-WARBLER is a beautiful little bird, the general tint of its plumage being a soft green, shading to a sulphur yellow, and the yellow passing into pure silvery white, beautiful and spotless; whence it has the local name of " linty white." Its 
form is light, without being feeble. It is very generally distributed through the wooded districts, preferring old plantations, and woods with tall trees. Its note is very peculiar, resembling the word "twēe,," repeated several times in succession; at first slowly, but afterwards in a hurried manner, and accompanied by a singular tremulous motion of the wings. Its sole food appears to be insects.

The WILLOW WARBLER is of frequent occurrence in gardens, plantations, hedges, and willow-grounds. It is very plentiful in the counties round about London; and is, on the whole, much more generally found than the preceding species. Its song, though possessing little variety, is soft and pleasing, consisting of several plaintive notes, in a regular descending scale. In appearance it is much like the wood warbler, being principally distinguished by its paler colour and shorter wings; but still more closely resembles the chiffchaff, from which it is, in fact, very difficult to distinguish it, except by the different colour of the markings on the egg. 


\section{PERCHING BIRDS}

\section{CHAPTER VI.}

The Piprts. The Meadow, the Tree, and the Rock PipitThe Chats. The Stone-chat-Its haunts the moor and the furze-Pleasing description of this little bird by Mr. Mudie - The Whin-chat-The Wheatear-A common British bird--Superstitious dislike to it in the NorthEsteemed as a bonne-bouche, in the South-The TrrsA numerous and diminutive race-The Tom-tit - The Long-tailed Tit-Description of its nest-The Blue TitA courageous little bird-Curious in its choice of nesting places-Anecdote of a tame titmouse.

ThE PIPITS partake in some degree of the character of the insect-eating birds, and partly of that of the lark. They are short-winged, and have feet well adapted for running. They nestle on the ground, and sometimes use hair for the lining of their nests, which is seldom or never done by the larks, with which they have been confounded. There are three regular British species, the meadow; the tree, and the rock pipit; and one accidental, Richard's pipit.

Of these the MEADOW PIPIT is very abundant, being freely distributed over the meadow grounds in summer, and the uplands in winter, at which latter season it is found among sheep which are folded on turnips. It is resident throughout the 
year, appearing to prefer uncultivated districts. This bird moves from place to place with short, unequal jerks; but when in full song it rises to a considerable height in the air, and with vibrating motion, singing as it descends and always returning to the ground, on which its nest is placed. Its plumage is sober olive brown, with a slight greenish and dull whitey tinge and dusky spots. The bird runs swiftly, and catches insects and worms readily. In many places it is called the titlark, or titling.

The тREк PIPIT much resembles the preceding; the main difference between them being in the length of the hind claw, and it is also rather larger. It is a summer-migrant, and is not uncommon in wooded districts, but is rarely or never found in the open country. When the male is in song, he generally springs by successive leaps to the top of a tree, where he rests awhile, and then leaps higher into the air, chirping as he ascends; he presently commences his song, and while uttering it, slides down with expanded wing and tail erected and spread, till he again reaches the tree, where he pauses, and then descends to the ground.

The ROCK PIPIT is common on rocky shores, in many parts of the kingdom; but it is never foumd inland. It is resident throughout the year. Its song and habits are similar to those of the two 
former species. It feeds on marine insects, and breeds in the clefts of the rocks. It is pleasant amid the storms and desolation of winter, on the sea-coast, to see this little bird "bobling" about, and braving the weather; and at that season he is almost the only winged creature to be met with upon long stretches of the beach.

The chats are well-marked, and distinct in their habits and character. Their bills resemble a little those of the insect-hawking birds, and their feet are well fitted for running. They dwell in the wilds, nestling under stones, furze bushes, and brushwood, on dry commons and heaths. They have not much song; their ordinary note is peculiar, not unlike the sound made by striking one pebble against another.

The stone chat is the only resident British species. It frequents dry moors, and lives among the thick brakes of furze, finding shelter and food there, even during the wirter season. Mr. Mudie says, "This is most truly the whin chat, as it summers and winters among the furze." His description of it is very pleasing. "These are very delightful birds. The furze-brakes are among the first places on which the sun of the young year shines out. The green and gold of the furze itself are gay and cheering; and it breathes a 
delicious odour. The black, white, and brown of this little bird contrast beautifully with the colour of the furze, as he sits on the topmost and luxuriant branch, ever and anon flinging himself a few feet into the air, hovering over the bushes, flitting now here, now there, and chaunting his little song, soft and persuasive, but low. It sings, too, till you are almost close upon it, and then drops so perpendicularly, that you imagine you have only to stoop, lift the side branch, and pick it up. But it glides through the bushes like magic, and appears hovering and singing again,--foiling all attempts at a capture."

The wHIN CHAT is similar in its haunts and habits to the preceding birds; but there is this difference, - the whin chats, almost to a bird, depart in autumn, to go farther south.

The whEATEAR, or fallow-chat, (as it is sometimes called,) is a summer migrant, and by far the most abundant as well as largest of its kind. It ranges all over these islands, being common everywhere on open downs and in uninclosed districts. It perches on clods, and especially on stones, beneath which it forms its nest, as well as in rabbit-burrows, and under the clods in fallow fields. Hence its names of fallow-chat, wheatear, and clod-hopper. These birds love a dripping sky and misty atmosphere; for their principal food is 
earth-worms, though they also take insects of various kinds. In the north, the wheatear is generally found on heaps of stones by ruins, or among the tombstones in burial grounds; and its haunts have got it an ill name with the Scotch. They call it the "clacheran ;" and the noise which it makes when alarmed, being not unlike that of breaking stones with a hammer, the superstitious ignorant fancy it is busy breaking the stones that are to cover their bones. Hence, the poor birds get killed and persecuted, and to destroy their eggrs is thought a good work.

In the south, the wheatear is highly esteemed as a bonne-bouche for the table; and when they collect in numbers on the southern downs, which they do about the middle of July, they are caught in horse-hair nooses and traps in vast numbers. At that time they are very fat, and of exquisite flavour. The shepherds supply them abundantly, placing traps for them in the turf of the downs, over which their flocks graze. The number of them taken every autumn, in the county of Sussex alone, is very extraordinary, and it is customary to dress them by dozens at the inns of the numerous watering-places on the Sussex coast.

The wheatear is a handsome bird; its colours being bluish-gray and black, the throat and rump whitish, and the breast of a buff-orange. 
There are seven British species of the TITs; namely, the great tit, the blue tit, the cole tit, the marsh tit, the long-tailed tit, the crested tit, and the bearded tit. They are a diminutive but sprightly race of birds, possessed both of much courage and much strength. Their general food consists of seeds, fruits, insects, and their eggs; and they will eat small pieces of meat, and particularly fat, of which they are very fond. They do not migrate, but sometimes make short flittings to and from other places, in search of food. Some of them will venture to attack birds twice or thrice their own size; and in this case they aim chiefly at the eyes. Their motions are rapid and agile, and they run with incessant activity along the branches of trees, and hang suspended from the twigs, hunting for their insect prey.*

The GREAT TIT or "tom-tit," is common in woods and gardens throughout the country. He is the largest of the species, and will frequently kill small birds; which he does by repeated blows of

* Mr. Yarrell observes that the great tit, the blue, the cole, the marsh, and the long-tailed tit, are each of them common around London. He adds that a young ornithological friend of his gave him a list of birds observed by himself in Kensington Gardens, including nearly seventy species (an unusually large number for so limited a locality in such a situation). The five species of tit: just named were included in the list. 
his hard and sharp beak on the skull of his victim. Afterwards he picks out and eats the brains.

The LONG-TAILED TIT is not uncommon in woods and shrubberies, in most parts of the kingdorn. The nest of this bird has already been described; It has always attracted attention as a model of beautiful architecture, and Mr. Yarrell says, "We have many accurate descriptions of it handed down from times when the habits and even the forms of birds were but imperfectly known." The same author pronounces this nest to be "altogether one of the most extraordinary of animal structures."

The bLUE TIT is one of the most courageous of his kind; and is well known among the bird-nesting boys of several counties, by the name of "Billy biter," from the recollection of the impression made by his hard and sharp beak upon their fingurs. The female is not easily driven from her nest, but defends it with great perseverance and valour, puffing out her feathers, hissing like an angry kitten, and pecking.

'These birds often choose the oddest and most conspicuous places for their nests. Not long since, a pair built in an old rat's nest; a dirinkingcup having been left in the hole of a wall, a little tit commenced building her nest in it the next day, and in a week she had laid eleven eggs. 


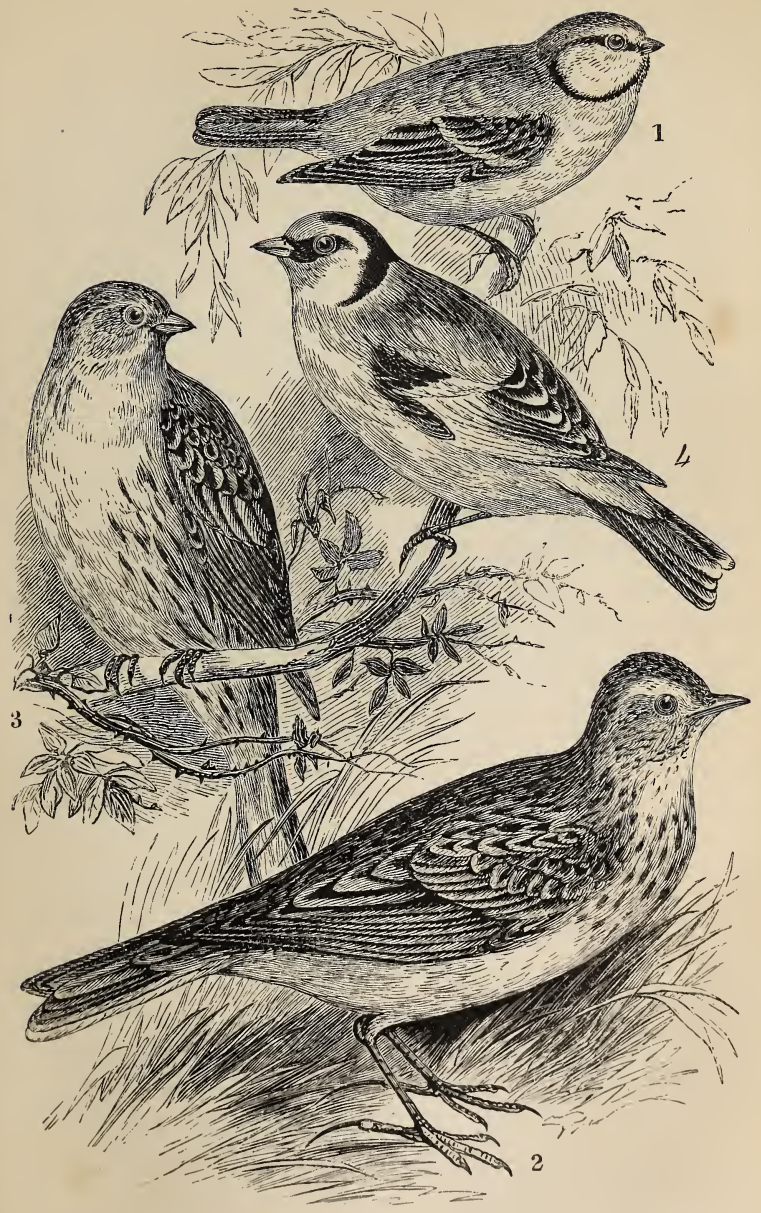

1. Tomtit, 2. Skylark, 3. Yellow-hamier. 4. Goldinch. 

Mr. Thompson says this is the most common species of titmouse in Ireland. He describes the manners of one in confinement, and says that, from its vivacity and familiarity, it was most amusing. It would cut through the netting of its cage, and fly into the room, attacking a bit of bread or cake in the children's hands, and absolutely refusing to quit hold, notwithstanding all the efforts of the child to drive it off. It was particularly fond of lump-sugar. Being confined in a cage with some other birds, it annoyed them sadly; its favourite trick was to pull the feathers out of its fellowprisoners, and it even tried this in the case of a song-thrush, but was successfully repelled. It escaped out of doors several times, but always returned without being sought for. 


\section{PERCHING BIRDS.}

CHAPTER VII.

The Larks. The Skylark-Its song-Nestles on the ground - The Buntings. A numerous race-The Yellow Bunting, or Yellow-hammer-Abundance and beauty of this birdCongregates with other field-birds in the winter-The Common Bunting-A mischievous propensity of this bird - The Black-headed or Reed Bunting-An inhabitant of marshy places, and the sides of lakes and ponds-The Snow Bunting-Affecting anecdote by Captain Lyon.

With the LARKS commences the division of the CONICAL-BEAKED PERCHERS; a distinction drawn from the form and great power of the beak. Many of the birds in this division live almost entirely on grain ; others on seeds ; and so great is the strength of the bill in some, that they can even crack the stones of various fruits, so as to get at the kernel.

There are three or four species of larks, of which the chief is the SKY-LARK- that bird whose joyous carol charms our ears and gladdens our hearts; the loved herald of the morn; sung by our great poet as such-

"Hark! hark! the lark at heaven's gate sings, And Phobus 'gins to rise . . . . "

On quivering wing the bird rises, almost perpendicularly, and by successive springs, mounting high and yet higher, singing as he goes, till he is 
lost from our sight; yet so powerful his voice, that its wild ecstatic strain, filling the air with glad melody, is heard distinctly when the strained eye can follow its course no longer. Poised aloft, he continues to pour forth his thrilling music in rapturous gushes; till again descending, he gradually suppresses his song, and abruptly closes it on reaching the ground. There is, perhaps, no sound in all nature's chorus so expressive of joy as this song. "Pretty bird! (thus does one of our admirable old divines apostrophize it) singing most sweetly and never ceasing his pleasant ditty while he hovereth aloft, as if he were there gazing into the glory of the sun; but is suddenly silenced when he falleth to the earth. So is the frame of the soul most delectable and divine while it keepeth in the view of God by contemplation; but, alas! we make there too short a stay, and down again we fall, and lay by our music."

Larks generally rest upon the ground, owing to the peculiar construction of their hind claws, which are very long and straight. They also build their nests on the ground, which exposes them to many dangers; but as they are exceedingly prolific their numbers are very great. The strong attacliment of the parent birds for their young is well-known; they will scarcely leave the nest to avoid the mower's scythe, and after the 
young are hatched, their watchfulness and care seem to increase. There are two or three cases recorded of the sky-lark moving its eggs, and even the young birds, under the fear of danger. Though living in pairs during summer, they are gregarious in winter, assembling in vast flocks, and feeding on the ground. They are then in excellent condition; whereas in summer they are lean.

The Buntings are a numerous race of birds, with which every one is familiar. There are seven British species: the Lapland bunting, the snow bunting, the common bunting, the reed bunting, the yellow bunting, the cirl bunting, and the ortolan bunting. Of these the yellow, the common, and the reed bunting, are the most generally diffused. They are marked by having very strong beaks; so formed as to be well-fitted for breaking. the shells, or rinds of seeds. The upper bill has a hard, bony knob. They live principally on grain and seeds, but also eat insects. These birds have plenty of voice, but no song; and are always very active in the heat of the day, keeping up an ircessant, though harsh and tuneless, chattering.

The yellow Bunting, or yellow-hammer, is one of our most common birds, as well as one of the handsomest; attracting the eye by its brilliant plumage, the fine lemon-yellow colour of the 
head and breast, and the rich chestnut and brown of the back. It is conspicuous almost everywhere, in summer particularly, frequenting all hedges, gardens, lanes and high-roads; and were it less common it would doubtless be much admired. The abundance and beauty of these birds do not, however, win them favour. Boys destroy their nests for very wantonness, and in the northern parts of the country, they were formerly regarded with a sort of superstitious dislike.

The yellow bunting is a bird of the cornfields; or at least of the richer parts of the country. It is very attentive to its duties in rearing its young; the old birds sit alternately on the nest, and when the brood are hatched, toil hard to supply their wants. When winter comes, they resort to more open places, and though they do not flock in such numbers as larks, yet they collect in open fields, near the copses and places they usually frequent. Though they do not actually migrate, they occasionally pass from the colder parts of the country to the warmer. At these times, they flock with chaffinches, greenfinches and others, mingling readily and harmoniously with them. At this season, they get very fat. In Italy, large quantities of this and the common bunting are caught and sold for the purposes of the table, together with the ortolan bunting: 
It has been noticed, that many of our little birds which get their living in company during the winter days, divide into their several families before they roost, and meet and associate again in the morning; on which occasions there is often a sort of welcome at meeting, and farewell at parting. They wheel about together, making the air resound with their little wings; and generally the yellow-hammers, at parting from their companions of the day, alight upon some tree or hedge, in numbers, and chatter together before betaking themselves to roost. What the song wants in quality seems to be made up in quantity; and they will sit for hours repeating their chirps, without even changing their position.

The common Bunting, though not so handsome a bird as the preceding, is larger, and, it should seem, hardier. Like the yellow-hammer, it frequents cornfields; and in Scotland goes by the name of the corn bunting. Its favourite grain is millet, and in countries where it is eaten it is fattened for the table with it. The cry (for it is more a screech than a song) of the male is usually uttered from the top of a liedge or bush; rarely from a tree. Sparrows, and other birds, will burrow in a stack and pilfer the corn; but the bunting appears to have a mischievous propensity peculiar to himself. "I saw (says Mr. Knapi) a 
rick of barley entirely stripped of its thatching: which this bird effected by seizing the end of the straw, and deliberately drawing it out, to search for any grain that might yet remain." Buntings are sometimes brought to market, and sold for larks; but they may be easily distinguished by the short bill, with its knob in the roof of the mouth, or simply by the colour, which is much darker on the under part, and by the short hind claw.

The BLACK-HEADED, or REED BUNTING is a wellknown inhabitant of marshy places, and the sides of lakes and ponds, and is always found near water. It is not uncommon, and remains in this country throughout the year. It has been sometimes mistaken for the reed warbler; but their habits and song are quite different. This bunting is about the size of the yellow-hammer; and its voice is as tuneless as the rest of its family. It is an energetic bird in the air; active in its movements, especially in that of the tail, which is even more rapid than in the wagtails. The bird has the habit of clinging to the flexible stalks of the water-plants, and the powerful and ready motion of the tail is absolutely necessary as a means of balancing. It rides with security and even grace when the stems are on a level with the water, adhering as if it were a part of the plant; and keeping its head to the wind. And when the 
autumn and winter winds have borne away the seeds, and blown down the reeds, the bird goes to other pastures, associating with its yellow brothers, and other grain-eating birds; and when the weather is severe approaching houses and farmyards.

Although the sNow BunTiNG, or Srow-FLAKE, is only a winter visitor to this country, it deserves a short notice on account of some interesting points in its history. It is, during the breeding season, an inhabitant of the Arctic regions and the islands of the Polar Sea ; and Linnæus, in his tour in Lapland, observes that it is said to be the only living animal that has been seen 2000 feet above the line of perpetual snow, in the Lapland Alps. A traveller in Norway says, "We saw the snow buntings in their beautiful plumage of black and white, and found a nest with the young under some loose stones." The male bird attends assiduously on his mate, and often rises up in the air when he goes from the nest, singing sweetly, and with his wings and tail spread like the tree pipit. It breeds in the northernmost of the American islands; and Captain Lyon found its nest of dry grass, carefully lined with a few feathers and the hair of the deer, at Sonthampton Island, singularly placed.

"Near the large graves," says the captain, in his interesting description of an Esquimaux 
burying-place, "was a third pile of stones, covering the body of a child, which was coiled up. . A snow bunting had fourd its way through the loose stones which composed this little tomb, and its now forsaken, neatly built nest, was found placed on the bosom of the child. As the snow bunting has all the domestic virtues of our English redbreast, it has always been considered by us as the robin of these dreary wilds, and its lively chirp and fearless confidence have rendered it respected by the most hungry sportsman. I could not, on this occasion, view its little nest, placed thus on the breast of infancy, without wishing that I possessed the power of poetically expressing the feelings it excited."

A number of the young birds of the year, bred in high northern latitudes, annually visit our islands. They are seen in the Hebrides, and also in Seotland, in little flocks, evidently family groups; they move in a compact body, and in whirling roving flights, immediately before or soon after a fall of snow. It is conjectured that the snow-fiake probably breeds on the higher Grampians. It is occasionally seen in large flocks along the marshes of the coast. 


\section{PERCHING BIRDS.}

\section{CHAPTER VIII.}

The Finches. The Chaffinch-Description of the habits and nesting of this bird-The Greater Redpole, or Common Linnet-Its habits, and beauty of plumage in the maleThe Lesser Redpole--Diminutive size and pretty manners of this little bird-'The Twite, or Mountain Linnet-The Greenfinch-One of our commonest birds-The Hawfinch -An extremely shy bird-The Goldfinch-Beauty and docility of this species-Tame Goldfinches-Anecdote of a collection of trained Goldfinches, Linnets, and Canaries.

The transition from the buntings to the FInches is easy; the principal difference consisting in the beak, which in the finch-tribe is conical, very thick at the base, and tapering to a sharp point. Their plumage varies much, according to sex and age, whence has arisen some confusion in the names given them-the same birds being called by different names. Of the numerous small birds included in this family, each exhibits, in its own domestic habits, as much skill and wisdom in the management of its concerns as the wisest of human kind. There is a difference between the music of the warblers, which is soft, mellow, and 
often deep, and the notes of the finches, which are loud, clear, and sometimes shrill.

The sPARRows form one genus of this family: and several of the finches are called LINNETs, because these birds eat the seeds of lint or flax, as well as hemp, of which, and all oily seeds, the whole family are particularly fond. They change their habits and places of resort with the seasons, flocking in winter, and moving their quarters according to the temperature. They are all useful to the farmer, by consuming the seeds of troublesome weeds, and they also destroy insects. Where these interesting little creatures are scarce, the weeds "get the better" of all the labours of human art, and, even in an economical point of view, their value is great.

The CHAFFINCH is one of our commonest birds, early in the season, and handsome. His bright colours and active habits, and lively, confident behaviour, (allowing a near approach without alarm,) have made him a general favourite. $\mathrm{He}$ is one of the commonest cage birds in France, and it is a common proverb in that country, "Gay as a chaffinch." The name of pink, by which this bird is known provincially, has reference to the sound of its call-note.

The chaffinch is about the size of the house sparrow, but more lightly and elegantly formed. 
In winter the females separate, and the males flock, feeding with other birds in the stubble lands, and in severe weather resorting to farmyards. The females migrate to the south of England in great numbers, and return in the spring to their breeding haunts. All the finches are remarkable for the neatness and beauty of the nests they construct, and the chaffinch is preeminently so. The nest is really a beautiful structure, and very neatly and compactly put together, so that it requires some force to pull it to pieces. In the "Field Naturalist's Magazine," there is an account of a pair of chaffinches that built so near to the sitting-room window of the writer, as to allow him to observe closely all their proceedings. The foundation of the nest was laid on the 12th April; the female alone worked at the nest-making, and by unwearied diligence finished her beautiful work in three weeks. She laid five eggs, and sat most patiently during thirteen days, at the end of which the brood was hatched.

The GREATER REDPOLE, or COMMON LINNET, is one of those birds about which there has been some confusion. It is called the limnet finch, the grey linnet, the white linnet, the brown linnet, and the greater redpole. The LINNET is the most general name. It is a gay and active bird, with 
sprightly and agreeable notes, and social disposition, and it is an exceedingly well-known one, existing in great numbers on most of the uncultivated lands of this country, appearing to prefer commons and fields of furze. Usually these birds are seen in flocks, roving about from place to place, feeding on small seeds, particularly those of flax, thistle, and dandelion. They usually prefer the thickest parts of furze-bushes for their nesting-places, or low bushy trees. In the breeding season the male becomes more richly tinted; the crown of the head is tinged with rose colour, and this hue, becoming lighter in shade, colours the breast, and fades to a pale peach on the sides. It is then called "the rose linnet." This beautiful colour is not seen in these birds in a state of confinement. Linnets are birds of very gentle dispositions, easily tamed, and capable of much attachment to those who feed them. Their song is cheerful and pleasing.

The LESSER REDPOLE is the smallest of the British linnets. It is known in the south of England as a winter visitor only, at which season considerable flocks make their appearance. Its note is a lively twitter, and its sprightly engaging habits, make it a favourite. It is one of the most easily tamed of the smaller birds, and will breed in confinement. The habits of unsuspecting confidence 
in these birds, have been noted by naturalists. Audubon, in his "Ornithological Biography," says that he saw them, in small parties of seren or eight, seemingly belonging to the same family, and that when fired at they all rose on the wing, and mixed together; but presently separated again into families, alighting on the same bushes, and resumed their occupation; and when alighted, were quite unsuspicious and allowed a near approach. They exhibited the most affectionate disposition, and it was pleasing to see several on a twig feeding each other, by passing a seed from bill to bill, one sometimes receiving from his two neighbours at the same time.

Their favourite haunts are the copses of hazel and birch trees, and the plantations of young timber, the catkins of those trees yielding them a plentiful supply of food. Their motions, when feeding, are remarkably agile; they are admirable perchers, and their action resembles that of the crested wrens and tits. On the twigs of a weeping birch, which are little thicker than packthread, these little creatures may be seen, swinging backwards and forwards, busily feeding, and never losing their perch.

There are two other British linnets, the TwITE, or MOUNTAIN-LINNET, a regular northern species, not uncommon in the neighbourhood of London, 
and in many of the eastern counties, during the winter season, flocking with sparrows and other small birds. At the approach of spring it retires to the northern and mountainous parts of England and Scotland, where it breeds. The particular note of the bird, resembling the word "twite" in its sound, has procured it that name. The other species, the MEALY REDPOLE, is an accidental one, and has been considered by many ornithologists to be merely a larger variety of the lesser redpole. It is larger, and the general plumage paler.

The GREen FINCH is one of our common birds, and remains with us through the year, only occasionally changing its ground in severe weather. It frequents gardens, orchards, and cultivated lands; and may be seen actively engaged among the branches and hedges, searching for seeds and insects. In the form of its bill, which is very large, it more resembles the sparrow; but in other respects it is more allied to the finches. It is a pretty bird, of soft and gentle appearance, and the tints of its plumage are subdued and blending, the predominant hues being olivegreen and yellow.

The largest British species of this genus is the HAWFINCH, Or COMMON GROSBEAK, which has been frequently described as merely a winter visitant, 
but it is now ascertained to be a resident throughout the year in some localities. It is particularly abundant at Epping Forest; its principal food there, being the seed of the hornbeam, a tree very prevalent in that locality. The extreme shyness of this bird is said to exceed that of every other land bird, so that it is very difficult to gain any acquaintance with its habits. When the young birds are able to provide for themselves they unite with the old ones in flocks, and remain so throughout the winter, feeding on the hormbeam seeds which have fallen to the ground, the newlycracked shells of which are seen, in abundance, at their haunts.

The hawfinch seems to have no song worthy the name. When a number are sitting together, they may be heard uttering a few notes, in a soft tone, something like those of the bully. The leugth of the bird, is full seven inches; the bill is prodigiously thick and strong.

There are many other birds belonging to this family, but those most generally known and common having been mentioned, there shall only be added to the list the GOLDFINCH, which is certainly one of the most beautiful as well as useful, of our resident birds. It is small, but powerfully winged, and very energetic in all its movements. Its chief food consists of the seeds of thistles, docks, and 
similar plants, especially injurious to the fields and pastures; and therefore, independently of its beauty and song, it claims the protection of the farmer, on the score of utility to his crops. If watched when feeding, the young birds may be seen climbing and clinging in all directions and positions about the stems of the seed-bearing plants, picking out their favourite parts. If approached too near, the little party, one by one, will move off to the nearest patch, with waving flight, twittering as they rise-

\section{“ . . . each outstretch'd wing,}

A fairy fan with golden sticks adorn'd."

And thus they rove, in small flocks, through the autumn and winter, living almost entirely on various seeds.

This bird is easily tamed and taught, and in addition to its capability of learning the notes of other birds, the tricks it may be made to perform are astonishing. Mr. Lyme, in his "British Song Birds," speaks of a collection of wonderfully trained goldfinches, linnets, and canaries, which was exhibited many years since. One of these birds appeared dead, and was held up by the tail or claw without giving any signs of life; a second stood on its head with its claws in the air; a third carried pails on its shoulders; a fourth 
appeared as soldier on guard, a fifth acted as cannoneer, and discharged a small cannon, and the same bird acted as if it had been wounded, was wheeled off in a barrow, and afterwards flew away before the company ; a sixth turned a kind of windmill; and the last bird stood in the midst of some fireworks, which were discharged all around it, without seeming the least afraid.

The goldfinch is long-lived, and one is known to have lived twenty-three years in confinemert. 


\section{PERCIING BIRDS.}

\section{CHAPTER IX.}

The Bulfinch-This bird in its wild state-Its great destructiveness-Amusing letter on the subject-Mode of training piping bulfinches-Four anecdotes illustrative of the strong attachment these birds are capable of-SPARRows - The Tree Sparrow-The House Sparrow-Habits of this bird, its nest and food-London Sparrow-Anecdote of the Cockney Sparrow and the keeper of the "Early Breakfast Shop"- "Are not two sparrows sold for one farthing?"

IHE BULFINCH is ranked between the grosbeaks and the crossbills. Though called in popular language a finch, it has none of the habits of the finches. With its form and manners as a cage bird we are well acquainted, but as a wild inhabitant of the woods it is comparatively unknown; for it is of rather shy and retiring habits, and is seldom seen associated with any but its orwn species. The natural song of the bird is a plaintive, softly modulated whistle, and so low that it cannot be heard but in its close vicinity. It inhabits all thickly wooded places, and also brakes and hedges, when not in exposed situations. Its shape is most compact and neat, and very expressive of 
energy and strength. The outline of the head and bill are fine, and the latter is strong in proportion to its size. Its bright black eye has a somewhat prying expression. It feeds on corn, seeds, and all sorts of berries, and the buds of most trees. It is very destructive in gardens, throughout the spring season; devouring the blossom buds of the various kinds of fruit, so as to destroy all prospects of the crop. Those buds which produce the leaves are passed over, and the foliage expands as usual, but the tree bears no fruit. From various authorities it appears that the bulfinch is a more decided bud-destroyer than any other of our birds. In winter it feeds on hips and haws and other seeds. These mischievous propensities make these birds serious foes to the orchards and gardens of the fruit districts; as is shown by such a note as the following, taken from " The Zoologist, for 1849."-_"Can you recommend any method of overcoming bulfinches, which last year have committed more ravages than usual in a secluded parish in the north of Devon, where they can harbour in surrounding plantations? Any advice on the subject, will be thankfully received by the clergyman of the parish, for the sake of his own crops and those of his poorer neighbours, in future."

An amusing note, appended to this, informs us that a stuffed cat, "placed in a conspicuous sitia-. 
tion, is a capital scare-bulfinch," but the droll warning is added, that it will be found useless to exercise ingenuity in making the cat look unnaturally horrible; for the birds are up to that trick, and pay no regard to a monster. So the nearer to nature, the better the scare..bully.

These birds breed rather late in the season. They are much attached to each other and their young, and it is believed they pair for life.

Bulfinches are much prized as cage-birds; in consequence of the readiness with which they learn to whistle musical airs; and their powers of memory, when well educated, and carefully attended to.

The mode of teaching and training them, is given, very fully, in "Bechstein's Cage Birds." The instruction should commence very early, and it is found the birds learm best just after eating. "The good and pure whistling of a man of taste," is preferable to any instrument that can be used. As the bird imitates exactly the sounds he hears, it is necessary to be perfectly accurate and in good tune. When one cannot whistle well the use of the flageolet is recommended in preference to other instruments. A single air is as much, generally, as the bird can learn and remember; but Bechstein, while he says this, adds that some can whistle distinctly three different airs, without con- 
fusing them in the least. In fact there are different degrees of capacity among bulfinches as well as other animals. One young bird will learn with ease and quickness; another slowly and with difficulty. But it has been observed that those which learn with most trouble, remember the songs, when once learned, better and longer; and rarely forget them, even during the moulting season, when the birds often entirely lose what they have acquired.

Several hundreds of taught birds are annually brought to Berlin, London, and other capitals, by the German birdsellers; the price varying from one to. several pounds each, according to the merits of the bird.

The bulfinch is very common in the mountainous forests of Germany, and it is from Cologne and other places in the Rhine districts that the market for them is principally supplied. Many of them are taught to sing by the weavers while at work in their looms; which is said to account for the birds beginning to sing when a person standing near them moves his head backwards and forwards.

To these attractive powers of the bulfinch must be added its obedience and capability of strong attachment, which it shows by a variety of little endearing actions; and it has been known even to repeat words 
with an accent and tone expressive of sensibility, so that one might almost suppose it understood their meaning. It delights much in being noticed, and expresses its pleasure by strutting about the cage, throwing itself into various attitudes, and singing a short simple air, in the low sweet tone of the uncultivated bird. This is their natural song, which the males may be heard chaunting to their mates during the hatching season.

Many instances of their attachment are recorded. Buffon says one was known to have escaped from an aviary, and lived at liberty in the woods for a whole year, and then, on hearing the voice of its beloved mistress, to have returned to her never more to leave her. Others, when parted from thuse who reared them, have died of grief. They have excellent memories, and it is stated that a bulfinch which had been thrown down in its cage by some rabble, during an émeute, fell into convulsions ever after at sight of any meanlooking person, and expired in one of these fits, eight months after the accident.

One of these birds which belonged to a lady was subject to frightfuldreams, during which it would fall from its perch, and beat itself against the cage, but no sooner did the voice of its mistress reach it, than, notwithstanding the darkness, it was at once tranquillized, and remounted the perch to sleep again. 
A most touching instance of affection in the bulfinch is that mentioned in Bishop Stanley's volume as having been told by Sir W. Parsons, who was himself a great musician, and who when a young man possessed a piping bulfinch, which he had taught to sing "God save the king." On his once going abroad he gave his favourite in charge to his sister, and when he returned she told him the poor little bird had long been ill, and was at that moment very much so. Full of sorrow, Sir William went into the room where the cage was, and opening the door, put in his hand and spoke to the bird. It knew his voice, opened its eyes, shook its feathers, and staggering on to his finger, piped "God save the king," and fell dead.

A similar anecdote, in which the bird seems to have died of sudden joy, is related by Mr. Thompson, who says, that a bulfinch kept by a lady had become so extremely attached to her, that he pined in her absence, and only seemed at rest when she was within sight. 'The lady fell sick, and was confined to her bed for a week with so severe an illness that she was entirely disabled from thinking of her pet. At length, when she was sufficiently recovered to see him, she ordered his cage to be brought and placed upon the bed beside-her. The bird knew her voice instantly, though it was weak 
and low from fever; the cage door was opened, he uttered a shrill cry of joy, between a song and a scream, fluttered from her hand to her cheek, and fell dead.

There are but two British species of SPARrowthe house and the tree sparrow. The bird which is known so generally by the name of hedge sparrow being quite of another family, and called rightly the hedge warbler, or accentor.

The TREE SPARRow is found chiefly in the midland parts of England, and does not migrate far fiom its native locality. It is an active and industrious little bird, inhabiting and nesting in the holes of decayed trees.

The HOUSE (or domestic) SPARROW, is known in every part of England. It inhabits the dwellings of the rich and the poor, taking possession of the humble thatched cottage in preference to the palace. So rarely is this bird seen far from the haunts of man, that the sight of one bespeaks a habitation near. Its nest is generally placed under the eaves of houses, or in the holes of old walls; and it is adapted in size and material to the place selected. If a thatch, tile, or hole, be not at hand, the sparrow will make a tree serve the purpose; but, in this case, as a rocfing seems always required, a dome of straw is formed, and an entrance made at the side large enough to 
admit the bird; and the nest is always perched on high, beyond the reach of enemies. All sorts of materials are used to form the nest; feathers, wool, cotton, or any stray substance at hand. Mr. Montagu mentions, that a pair of sparrows in his garden carried off a long piece of matting which had been tied round some lettuces, and conveyed it to their nest, under the tiles. It seemed, however, they could not manage it skilfully, for both birds got their legs so inextricably entangled in it that they were held close prisoners. The extraordinary outcry raised by their neighbour sparrows, who assembled to gaze at the unfortunate pair, (not attempting to aid them, attracted attention, and they were released, but not till they had been so much exhausted by their struggles that they shortly after died.

One food of sparrows is the house-fly, which were it not for them would multiply to an intolerable extent. They are also incessant in the destruction of the cabluage-butterflies, and are very useful scavengers in clearing away small offal of various sorts. They are voracious birds, and very energetic, and may be seen congregating in clusters with a great deal of noise and clatter. Their attachment to their young is very pleasing; and numerous instances of it are mentioned in works on natural history. 
The impudence of London sparrows is proverbial; and they have a good excuse for it, as they must use their wits or die of hunger. An amusing justance is given in "The Zoologist, for 1851," of a cockney sparrow which had for three or four years maintained a close friendship with the keeper of an "early breakfast shop," composed of a long flat wheelbarrow, with a movable awning, which was daily established at early dawn at a corner of Tavistock-square, immediately opposite a solitary plane-tree-the favourite resort of myriads of house-sparrows. Among this host was one female sparrow, between whom and the old man who sold the bread and butter and coffee at this humble caravan, the most friendly and intimate relations existed. They every morning breakfasted together ; the bird making herself completely at home, and seeming to believe the whole establishment was maintained for her particular benefit. She had three broods every season, and as soon as her young ones needed food she made larger claims on the good man's stores.

Every morning came the wheelbarrow, and every morning the sparrow fed herself and brood; and if the old man, in the dark wintry mornings, were a few minutes behind time, she would go some way to meet him, and with a chirp at meeting settle either on or beneath the awning, and 
so ride home. And this was done not once only, but regularly and as often as he was too late. Once only there was a season of estrangement between the two friends. The bird brought down from the tree three of her young, one of which was too weak to get up again; and the old man, out of compassion, took the poor little fledgling home with him. Unfortunately it died in the course of the day. A complete change now took place in the conduct of the sparrow. She refused to approach her friend's shop; in vain he coaxed and called her, tempting her with tit-bits, and trying all his arts to be reconciled. Her former chirp of confidence was changed into a harsh note of reproach and remonstrance; and so long did her displeasure last, that the offender began to despair of ever regaining the affection of his pet. But in due time another brood was hatched, and the mother forgot old griefs in her new joys; the friends were reconciled, and they lived together on the old footing of familiar confidence and goodwill.

I must own to a special liking for the sparrow. Its attachment to the dwellings of man, the lively and inspiriting sound of its well known "cheerup," and, in short, the feeling of home connected with it, all form a host of agreeable associations which combine to render the bird dear; and there 
is one recollection that it brings to mind, which more than all the rest is cheering, as telling the goodness and providence of God; I mean the allusion made to it by the Saviour, when, for the encouragement of his disciples, he said, "Are not two sparrows sold for a farthing? and one of them shall not fall on the ground without your Father. Fear not therefore, ye are of more value than many sparrows."*

* Matthew x. 29, 31. 


\section{PERCHING BIRDS.}

\section{CHAPTER X.}

Swallows-Their utility-Migration-The Sand MartinA colony of these birds described-The Chimney Swallow and the Martin - Their habits and instincts - The Ancients and the Swallows-Affecting instance of parental affection in a pair of Martins-The Swift--A denizen of the air-Preys upon spiders-Migrates early -The Night-jar, or Goatsucker-This bird the Swallow of the night, or twilight-Peculiarities of its conformation - A moth-hunter - A summer's night passed amid the haunts of the Night-jar.

Amovg the most conspicuous of our summer birds, are the family of the swaLLows, birds with whose appearance we associate the idea of winter's departure and summer's approach. Favourites of all, and hailed with delight, these most charming and intelligent birds are of the utmost utility in destroying myriads of our minute winged foes, which without their aid would render the labour of the husbandman comparatively fruitless. They may be considered as the guardians of our fields, asid deserve to be everywhere protected.

In proof of their great value as insect-destroyers, 


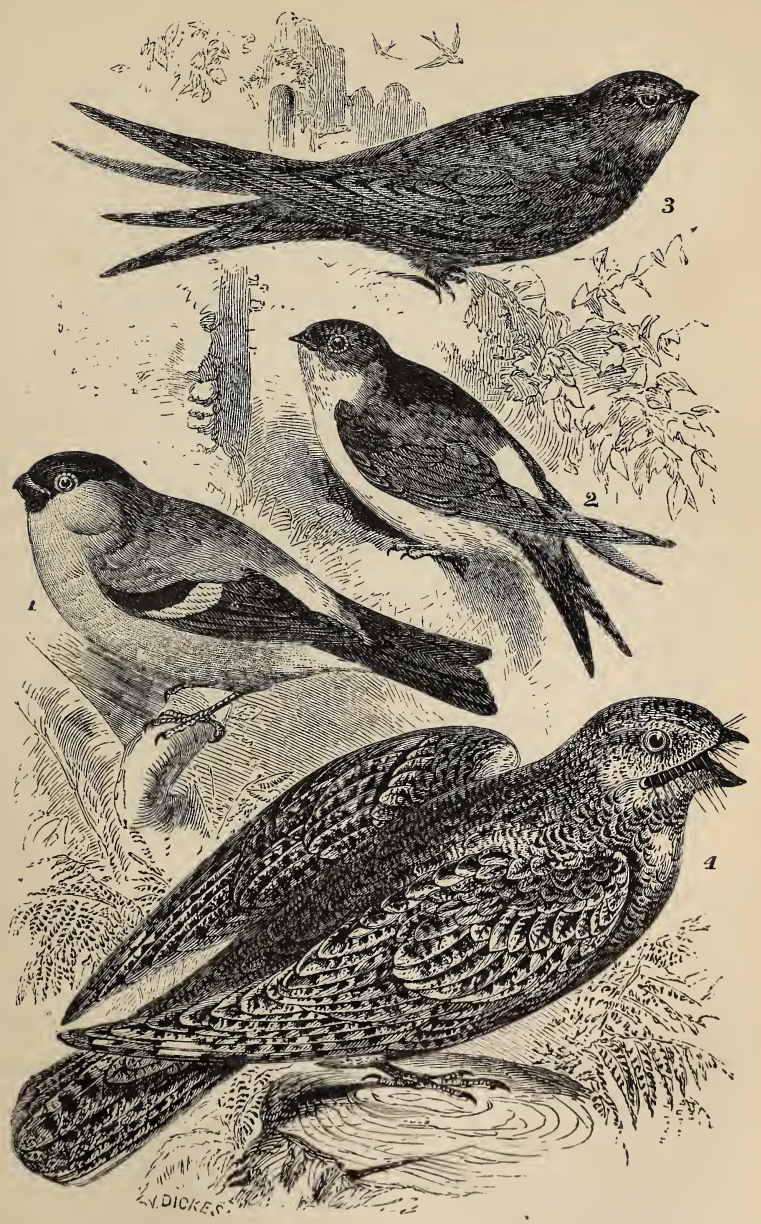

1. Bulfinch. 2. Common Martin. 3. Common Swift.

4. NightJar. 

Mr. Jesse says that he was informed by a clergyman of his acquaintance, that in an adjoining parish to his own some young farmers formed themselves into a club for the purpose of practising shooting flying, and they exercised their skill on the swallows which frequented their hopgrounds. The consequence was that the hops were covered with insects and altogether blighted; while in the same year the hop-grounds in his parish were perfectly free from blight, and produced an abundant crop, he doing all that he could to encourage the swallows. This author suggests that persons having hop-grounds would do well to erect rough buildings in them, with projecting eaves, affording facilities for these birds to build under them. If this expedient were tried he thinks that much of the blight from insects, about which great complaints are made, would not take place.

The migration of the swallow tribe has been noticed by all observers of the habits of birds. The subject of the periodical arrival and departure of our migratory birds, is one of deep interest to the lover of natural history, and certainly there is no instinct which seems to act upon them more forcibly, or which is so deeply involved in mystery.

The times of these flittings are observed with the most astonishing order and punctuality; but 
the secresy of their departure and the suddenness of their reappearance have involved the matter generally in great difficulties. As to the causes that induce this habit we are much in the dark; there are two principal ones usually assigned, namely, the want of food, and the want of a proper temperature of air and conrenient places for the great work of breeding and rearing their young. But though these reasons undoubtedly operate to a large extent, they will not be found to hold good in every instance, when closely inquired into.

Then, as to the manner in which these surprisingly long journeys are performed, we may ask many questions which we cannot answer. We do not know by what means they subsist during the period so oceupied, nor can we tell why it is that in the case of our summer migrants, the males always precede the other sex in their time of arrival. In short, after all our inquiries into this branch of natural economy, much yet remains to be learned, and we may say, with that delightful naturalist Mr. White, that "whilst we observe with delight with how much ardour and punctuality these little birds obey the strong impulse imprinted on their minds by their great Creator, it is with no small degree of mortification we reflect that, after all our pains and inquiries, we are not yet quite certain to what regions they do migrate, 
and are still further embarrassed to find that some do not actually migrate at all."

Some have asserted that swallows do not leave our country, but exist in a torpid state; and some have even maintained, that they lie at the bottom of lakes and rivers, clustered together. The facts of the case are now well established. They appear in England in April, and are generally all gone by the end of the month of September; but some of the late broods are not capable of the journey, and so remain, and are found, either dead, or in a benumbed state, in holes of walls, or unter hedges; partly no doubt, from the cold, and partly from want of food; but these instances are not common, and will not support the inference, that, if any of them survive, the whole species is preserved in the same manner.

"Amusive birds! say, where your hid retreat When the frost rages and the tempests beat? Whence your return, by such nice instinct led, When spring, sweet season, lifts her blooming head? Such baffled searches mock man's prying pride, The God of nature is your secret guide."

Much interest and amusement may be derived from watching and noting the arrival and departure of our migratory birds; every ornithologist endeavours to ascertain what species are migratory in the district in which he is resident, and to 
determine, as far as possible, the exact times of their appearance and disappearance. In this manner much valuable information has been collected, and data furnished of great importance to the student.* Let none suppose, however, that there is so much on record already upon this and kindred habits of birds, that there is nothing more to be learned. The great naturalist, Ray, has observed, that, so rich is nature, that a man born a thousand ages hence will still find enough left for him to do and notice, $\uparrow$ and the author from whom we have just now quoted (White) begins a letter giving an account of that rare bird the stilt-plover, which he had just procured in his own neighbourhood in these words :- "It is now more than forty

* Bishop Stanley gives the annexed short list of a few of the most common of our migratory birds, together with the dates of their appearance and departure as observed by him.

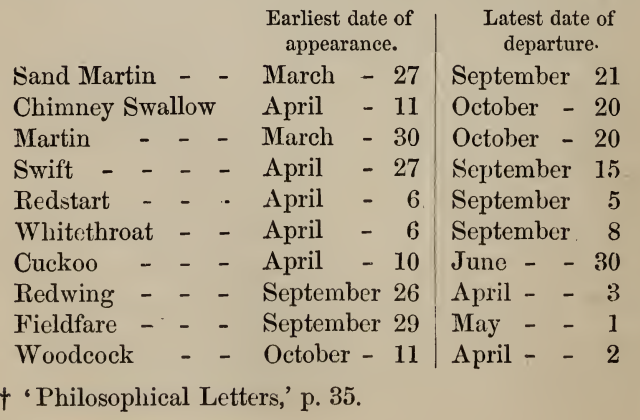


years that I have paid some attention to ornithology in this district without being able to exhaust the subject: new occurrences still arise as long as any inquiries are kept alive."

There are four British species of swallows. 'The SAND MARTIN, a small brownish bird, by far the least of any of our swallows, comes first, and may be seen early in April hurrying over the surface of large sheets of water or rivers, near which are banks of sandy soil, in which these birds burrow and build their nests.* A colony of sand-martins in considerable numbers, especially when they are forming a settlement, presents a very busy scene. They dig away with great assiduity, using their bills as pickaxes, and shovelling out the sand with their feet, making so deep a burrow that it is not easy to reach the nest; the entrance, too, is . so small, that no bird of prey can gain access, and the steep is, generally, so great, that the small animals which suck eggs are not able to climb it. These birds are no songsters, only making a little harsh noise when any person approaches their nests.

* It is remarkable that after some years the old holes are left and new ones bored. Perhaps because they become foul from long use, or they may so abound with fleas as to be untenable. This species of swallow is strangely annoyed with fleas. 
Next to these appear the chimney swallow and the MaRTin. The large screaming swallow, or SwIFT, is the last to come and the first to go. These are all insect-eaters, which they capture while they fly. Their wings are very strong and long, and their tails pointed in forks; so that they can remain the whole day wheeling in the air in pursuit of their prey. Their form is that which has been found to make the fastest sailing-vesselfull forwards, and long and tapering backwards. Their feet are small, but these, as well as the stiff points of the tail, and even the edges of their wings, are so formed that they can cling to an upright or even an overhanging surface, if there be roughness for their claws to hold by. Their sight is exceedingly acute, and their bills flat and very wide at the base, and curved; so that they can carry a large supply to their nests for the young.

Swallows and martins are birds which, like the sparrow, display most strongly social feelings towards man. They invariably attach themselves to our houses ; they claim the shelter of our dwellings, and for this purpose pursue us in all quarters of the world and in every latitude. This habit of the swallow has obtained the notice of the Psalmist, who says, "The sparrow hath found an house, and the swallow a nest for herself, where she may lay her young, even thine altars, O Lord of 
hosts."* These birds are, accordingly, privileged; forbearance is shown towards them, and the boys of England, though alas! too often they heedlessly inflict suffering on animals, will rarely disturb their nests; so that, although frequently seen attached to low houses within easy reach, they are generally suffered to hatch and depart in safety.

The ancients generally mention the swallow as wintering in Africa. It seems to have been as great a favourite with them as it is at the present day. The Grecians welcomed its annual return with gladness; and the Rhodians had a festival, when the boys carried about young swallows, singing a lively carol, which has been preserved in the works of Meursius:

"He comes, he comes, who loves to bear Soft sunny hours, and seasons fair;The swallow hither comes to rest His sable wing, and snowy breast."

This song the troops of Rhodian children sang in chorus, from door to door, collecting little gifts in return : a pleasing custom.

There seems to be scarcely any portion of the known world in which swallows are not found in certain seasons of the year, and almost everywhere they have their stated periods of migration and

$$
\text { * Ps. Ixxxiv. } 3 .
$$


reappearance. According to the Greek calendar of Flora, kept by Theophrastus at Athens, the Ornithian winds blow and the swallow comes between the 28th of February, and the 12th of March ; the kite and nightingale appear between the 11th and 26th of March; and the cuckoo appears at the time the young figs come out, and thence his name. Among the Greeks, it seems the crane pointed out the time of sowing; the arrival of the kite, the time of sheepshearing; and the swalluw, the time to put on summer clothes.

In Sweden, the swallow builds in barns; and in the warmer parts of Europe, where there are no chimneys, she constructs her nest in porches, gateways, and similar situations. Here she prefers to breed in chimneys, and loves to haunt those stacks where there is a constant fire; doubtless, for the sake of the warmth. Some five or six feet down the chimney, about the middle of May, this little bird begins to make her nest, composed of mud or dirt, shaped something like half a deep dish, and lined within with grasses and feathers. It has been supposed that the object in selecting such an inconvenient situation for building, is, to secure the young broods from rapacious birds, and particularly owls, which often fall down chimneys, probably in the effort to reach these nestlings.

The martin nestles in the upper angles of 
windows, and under the eaves of houses ; forming its nest of mud or clay, with a small hole on one side for entrance, and when finished it is frequently occupied by both birds at the same time. The habits of the martin closely resemble those of the swallow, and they, as well as the swift, return to the places, and even to the nests, which they inhabited during previous seasons. There appears ample proof of this, as experiments have been made by marking the birds, which have again and again been found to return to their old haunts.

House MaRTins are distinguished from their congeners by having their legs covered with soft, downy feathers, down to their toes. They are no songsters, but twitter, in a pretty, inward, soft manner, in their nests.

A touching instance of parental affection in a pair of martins, is given in "The Zoologist, for 1851." At the time of the autumnal migration, these birds were, unfortunately, engaged in rearing a young brood. They suffered the season to pass away, and remained behind. It was observed that towards the end of October, they became visibly weaker-they were seen less frequently, by degrees, and at length they wholly disappeared. They were forgotten, and their fate unknown, until, in the following spring, a nest was removed from the eaves, contrining the skele- 
tons of three half-fledged young, and over them those of the two old birds. Thus, faithful to the last, they had perished, a sacrifice to parental love.

The SWIFT is the largest of our swallow tribe, and perhaps the most powerfully winged, for its size of all our birds. Its whole structure is more adapted to an aërial existence than that of any other bird. Placed on level ground, it is utterly helpless; but, in the air it is all life. This bird frequents the highest places, and at a considerable elevation haunts the air for food. Its stay with us is short; it seldom appears before the middle of May, and disappears about the middle of August. It is said that spiders form a very considerable part of the food of the swift. This may seem almost incredible, considering the height at which they seek their prey. The fact is, the air is often filled with small spiders, at a very surprising altitude. Of their quantity some idea may be formed, by the perfect carpeting of webs, occasionally seen on an autumnal morning, glistening with moisture. These are the webs of the gossamer spiders, which, weighed by the dew, fall to the ground, and cover whole acres. As the time approaches for the swifts to depart, they congregate in large bodies, and appear all day on the wing, in multitudes; gliding, dashing, wheeling, 
playing numerous antics, joyously screaming tc each other, full of energy and life. These meetings continue till towards the middle of August, after which, the birds are no more seen.

The NIGHT-JAR, or GOATSUCKER, (as it is improperly called,) is the night, or twilight swallow, being the only British nocturnal bird, among our summer visitants. It feeds on night moths and gnats, and hence it prefers moors, heaths, and ommons, where these insects abound. It has a row of hairs, or bristles, on the side of the bill, and an enormously wide, gaping mouth, and its eye is large, full, and clear, like the owl's. This bird has also a remarkable peculiarity in the foot. 'The hinder toe is capable of being reversed, so as to turn forward, with the other three; which is, probably, an acommodation to its habit of perching lengthways. The middle toe, likewise, is st rrated, or toothed-probably to aid it in the capture and retention of its quick and active prey.

The night-jar, is so called from the particular noise it makes, which resembles the sound of a spinning-wheel; and is a compound of hissing and booming. This bird does not arrive till the middle of May; and departs early in September. When hawking for moths, it flies with its mouth widely extended, making its peculiar noise; and 
but slightly stirring the air with its wings. When moth hunting, it glides round and round some tree where these insects are often on the wing, and darting in, captures them, by the aid of its bristles, and the glutinous matter which adheres to its bill, and which is so adhesive, that small insects are retained by it.

The song of the night-jar is thus described by a naturalist: "It was a fine, warm, summer's night, in June, in a wild part of the country, between Bromley and Chiselhurst, Kent. Night came on, as I reached a beautiful meadow, bounded by a thick wood, and in which the hay was cut, ready for carrying. Here I made a soft, warm, fragrant bed; and had not rested long, ere sleep overcame me. How long I had slept, I know not; but, on awaking, my attention was soon drawn to the singular, wild, ringing strain of the night-jar. It resembled, at times, the whirring, rapid rotation of a wheel, now swelling; now diminishing; the sounds intermixed with curring, croaking notes, some of them having a ventrilnquial effect. Now and then, there was a sharp, unearthly kind of shriek; presently the same sound seemed issuing from other quarters of the wood, till the whole place was ringing with the wild, nocturnal notes. As daybreak advanced, I could see the birds, (from four to six, ) hawking for moths, chasing each other, 
and sweeping along with surprising turns and tumblings. I sat, motionless, with my head just above the haycock; and I saw them well. They were continually snapping at the numerous small moths, which were hovering over the heaps of hay; opening their wide, toad-like mouths, and gliding, swallow-like, with noiseless, wheeling flight." 


\section{PERCHING BIRDS.}

\section{CHAPTER XI.}

The Climbing Brrds-The Woodpeckers-Their habits and haunts-The Green, the Great, and the Lesser spotted Woodpeckers-The Green Woodpecker-The WryneckThe Nuthatch-The Creeper-Its diminutiveness, agility, and hardihood--The Cuckoo-Its strange habit of depositing its egg in the nests of other birds-A Cuckoo carrying her egg in her bill-Unaccountable attachment of other birds to the Cuckoo-Its mode of hunting for food-The Bee eater-The Hoopoe-The Kingfisher-"Halcyon days" -Parrots-Account of Parrots at large in NorfolkCurious anecdote of two Parrots in the Zoological Gardens.

WE come next, to the CLIMBERs; $i$. e., birds which are remarkable for their power of climbing; for which purpose, most of them are "yoke-toed;" i. e., have their toes arranged in pairs.

The wOodPEckers are a peculiar family, whose habits are well known. They are shy and retired birds; living in or near woods, and concealing themselves from view, by passing to the side of the tree or branch opposite to the observer. They. search the bark of trees for insects, creeping, or climbing along the trunk and stems. Their tongues are capable of great elongation, and are barbed at the end; and they have a glutinous secretion in 


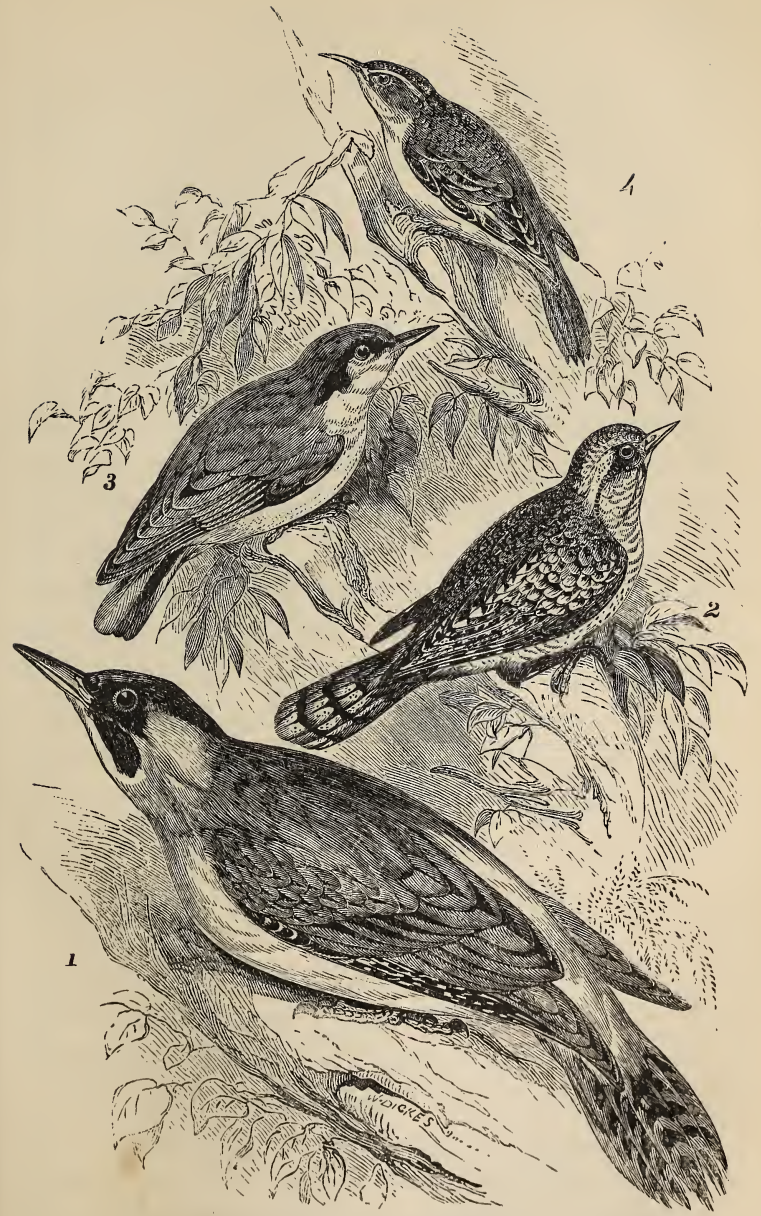

1. Green Woodphoker. 2. The Wryneck. 3. Nuthatch. 4. Common Creepel. 

their throats, which takes up small insects by adhesion. They live in the holes of trees, some of which they make, or partially enlarge, by the aid of their strong and sharp bills; and in these holes they deposit their eggs.

An old tree is everything to the woodpecker, for there he finds food, shelter, and a nursery. There are countless beetles, flies, and grubs, which mine into the old wood, and drill it through and through. For these he digs into the bark with his beak; but he uses his tongue in drawing them out, as with a hook. When he comes to a hollow place he taps it with his bill, making a noise like the beating of a drum. He utters a noisy, merry note, which has been compared to a laugh, and it is said that this sound is more frequently heard when rain is at hand. Hence, he has been called the rain-bird; and it is worthy of note that these birds were called by the old Romans Pluvice Aves, for the same reason.

There are three or four kinds found in this country-the green, the great, and the lesserspotted woodpeckers ; but, with allowance for difference of situation, the habits of all are the same.

The GREEN WOODPECKER is the most common, and accordingly the best known among British species, and is found over most of the wooded. districts of England and Scotland. Insects of 
various sorts, especially ants and their eggs, form the principal food of this bird, and it is accordingly more frequently seen on the ground than any of the others. It is also alleged to be a great enemy to bees. When excavating a hole in a tree for the purpose of nesting, it is said these birds will carry the chips away to a distance, in order that they may not lead to a discovery of their retreat, as other birds are known to carry away the eggshells and offal of their young ones. The green woodpecker makes no nest, but lays its eggs on the loose soft fragments of the decayed wood. It is one of the earliest birds to retire to rest in the afternoon. Besides the name of rain-bird, it has various other provincial appellations, as woodspite, hew pole, yaffle, whitill, and woodpie, or woodwale. In the popular poem of the "Peacock at Home," the following couplet occurs :-

"The skylark in ecstasy sang from a cloud, And chanticleer crow'd, and the yaffil laugh'd lond."

The wrYNeck is a curious and beautiful little bird, which, although it is nearly related to the woodpeckers, is distinct from them. It is a $\mathrm{com}^{-}$ mon and well-known summer visitant, arriving iust before the cuckoo; from which circumstance it has been called "the cuckoo's mate." It lives on insects and small ants, which it finds in abund- 
ance on the stems and branches of trees, and captures with its tongue, which it can protrude at least an inch, and then draw in with the rapidity of lightning. When it is thus engaged, whether on a tree or the ground, its body is motionless, but its head is continually moving from side to side, and twining with a serpentine action, whence its name; and it is also called in some counties, the snake-bird.

Without any rich or brilliant colour in its plumage, the wryneck is still a handsome bird, from the singularly beautiful manner in which the various markings and the shades of brown and gray are mingled. It is solitary in its habits, being very seldom seen with any other bird than its own mate, and that but a limited portion of the year. The young are easily tamed, and are great favourites with boys in this country, but more particularly so in France, where it is customary to tie a piece of string to one of the legs of the bird, and carrying it from one tree to another to allow it to search the bark for insects, and when brought back by the string, it climbs with equal facility over any part of their clothes. The female bird is rather larger than the male. The note is a sharp sound repeated several times, and not unlike the whistle of the kestril.

The nut HATch, and the TREe CREEPER are two 
of the climbing birds, which attract attention in the woods.* The former is a small grayish, bluebacked bird, which runs and creeps, more like a mouse than a bird, when climbing the branches; and may be heard rapping away with all its force, high up in the trees, either examining the bark for insects, or busily engaged in hammering nuts to pieces, which it manages by first adroitly fixing the nut in some crevice of the bark, and then. striking it with all its might, breaking the shell, and catching up the kernel before it falls. It is a great favourite with observers, is resident here all the year, and frequents woods and plantations in the winter, being sometimes seen in orchards and gardens.

The actions of this bird are very interesting. Like the other true climbers, it builds in holes; if the external hole is large the nut hatch plasters up part of it with mud; and if the plastering be removed, the bird almost invariably renews it, the first or second day. As it has frequent and obstinate battles with some of the titmice for the possession of a favourite locality for nesting, this may be the reason for this proceeding, since the smallest breach is most easily defended. In reference to this habit of working with plaster, one of

* They are not yoke-toed, and are without the extensile tongue of the wryneck and woodpecker. 
the names given to this bird in France is pic-maçon. Birdnesting boys when they find a hole that has been recently plastered are almost certain of finding it tenanted.

The nuthatch hides nuts, probably for a supply in hard times, because its food consists entirely of those kinds that are only to be had otherwise at certain seasons. One of these birds was seen in the act of concealing a nut. It flew past a window with a large nut in its bill, which it proceeded to fix into several crevices in the dry ground, where it could get a purchase, but after repeated blows, which failed in cracking the shell, it appeared to give the matter up as hopeless. It was then observed to carry the nut a yard or two, and push it by main force into a crevice near the area, and then catching up two or three pieces of moss care. fully and completely to cover it with them, which done, it flew away.

It is resident here all the year, approaching orchards and gardens in the winter, but is not equally numerous in every district.

The little creeper, also, like the nuthatch, glides up and down the stems of trees. It is a most interesting little creature, and with the exception of the golden-crested wren, is the smallest of the British birds. So light is it, that the most slender twig will bear it, and it rums over the 
branches in all directions, not only upwards and downwards, and across the perpendicular trunks, but with its back undermost, on the lower side of branches, with incredible rapidity. Its object is to pick out of the little crevices of the bark those minute insects and their eggs which are passed over by the larger birds; and as the active little being visits all places, woods, copses, hedgerows, shrubberies, gardens and orchards, it saves us many a fruit and flower and shoot, which would otherwise have fallen a victim to the canker.

These minute creatures are abroad in the hardest frosts and deepest snows. They appear to be but little affected by cold; and as they find their food on the trunks of trees, which are uncovered when the tree itself is mantled in snow, they have their table ready spread at all seasons, when many other birds perish or save themselves by flight. They show great sagacity in their mode of proceeding when busied in an orchard, seldom ascending higher than the boughs ; and by some singular instinct they distinguish those they have once examined, and rarely, if ever, visit them a second time.

The cuckoo is a well known and most curious bird, and has always been a subject of much interest and inquiry to the ornithologist. Every one has heard his unique and peculiar note, sound- 
ing clear and strong in the woods. The bird itself may be easily seen flying hurriedly and apparently neavily, from one tree to another, usually followed by a few small birds in its train. The various stages of its progress, during its sojourn here, have been also noted in the popular couplet:-

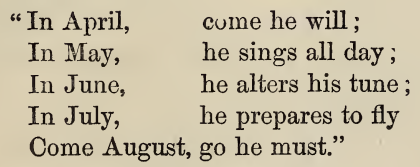

Singular as the cry of this bird is, still more singular is its strange, unnatural habit of leaving other birds to take care of its young. That this is the case has been proved by numerous instances.

Not only bave the eggs of the cuckoo been found in the nests of many of the smaller birds, but the young cuckoo has been seen to turn out the lawful progeny of its foster parents, and the latter, (strangest of all) to feed the intruder with eagerness, apparently regardless, or unwitting of the fate of their own young. The nests usually chosen by the cuckoo to deposit her eggrs in, are those of the hedge-sparrow, the wagtail, the titlark, the yellow hammer, and various others; but the hedge-sparrow seems preferred to any. The smallness of the cuckno's egg, in proportion to the size of the 
bird, is a singular circumstance, and seerns to favour this mysterious instinct.

It does not appear that any one has actually seen the cuckoo deposit an egg; so that we have had only conjectures as to the way in which it is done. It was supposed, from analogy, probably, that she carried it in her bill, and dropped it into the nest; and this idea seeems confirmed by an instance mentioned in "The Zoologist, for 1851." A person shooting on the banks of the Norwich river, on the 14th of April, in that year, saw a flying cuckoo, which was carrying something in its bill. He followed the bird in a boat, and saw it alight on a meadow. Approaching it within twenty yards, he perceived it crawling like a parrot, along the side of a drain, still carrying something in its beak. After a time, the bird stopped short, when he fired and killed it. On exanination, it proved to be an egg, which the cuckoo was carrying; and it seems highly probable that she was in the act of searching for a nest in which to deposit it.

There is another strange fact connected with this mysterious business. Not only is the little hedge-sparrow induced to regard an enormous, ravenous cuckoo, as her own dear little one, but the young cuckoo seems to have a strange power over the affections of other birds, whose assistance 


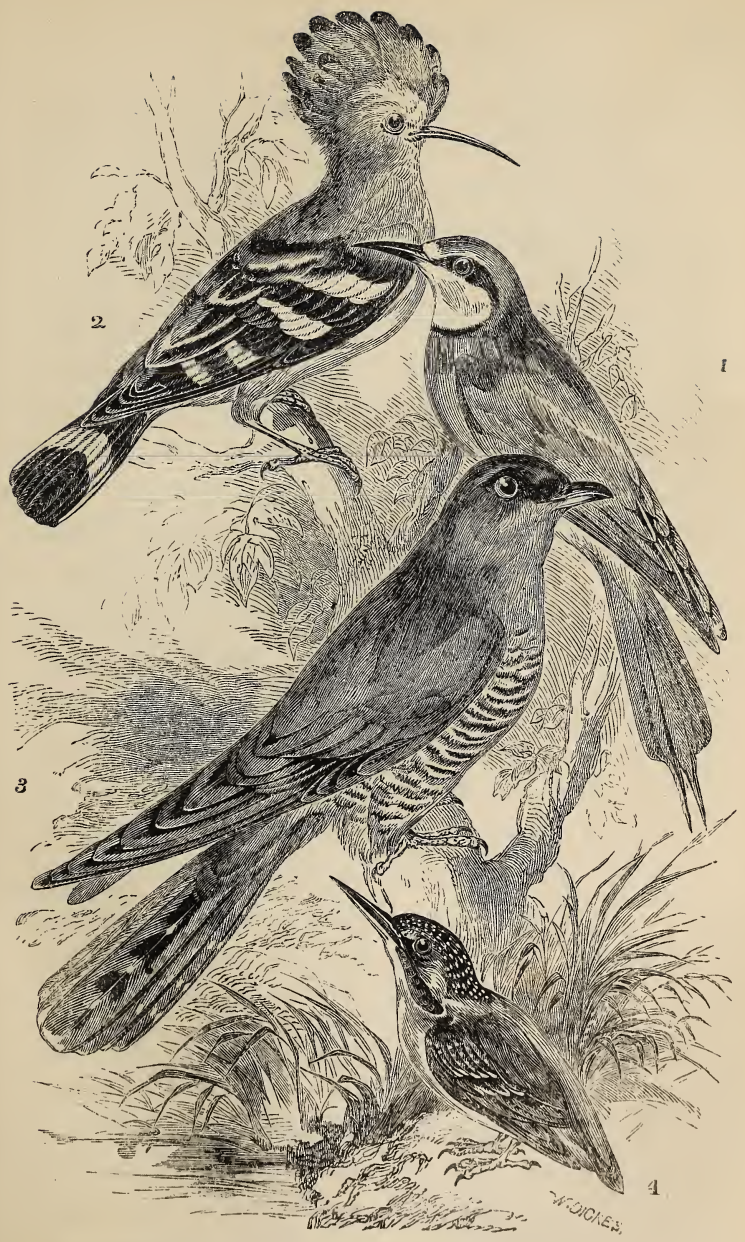

1. Bee-eater, 2. Hoopoe. 3. Cuchoo. 4. Kingfisher. 

it requires. A young cuckoo was taken from the nest, and put in a cage with a young thrush, which could feed itself. In a short time the latter was observed to undertake the task of feeding its companion, and it continued to do so with the most assiduous attention, and every mark of affection, seeming always ready to drop food into the voracious throat of the young monster. The common wagtail, the hedge-sparrow, and the titlark, have been repeatedly seen following young cuckoos, and feeding them, in the months of June and July in successive summers.

It has been supposed by some, that the small birds follow the cuckoo in the way they do, for the sake of annoyance, as they will a sparrowhawk. But their behaviour is wholly different in the two cases. The attendance on the cuckoo is at a distance, silent and respectful ; whereas, in the other instance, there is a hue and cry raised, which annoys and discomfits the culprit. "The lesser birds are mightily taken up with a cuckoo," was the remark of an old bird-stuffer; and his accuracy of observation in this, as in other points, is borne out by facts, for which, however, no sne is able to account. This strange irregularity is doubtless ordained by the Creator for a wise pur pose ; and we may safely conclude that the exemption of the cuckoo from what are the severest 
labours of other birds-nest-building, and rearing their young-answers some useful end in the economy of nature.

The cuckoo feeds on insects and their caterpillars, and as these are highly injurious to trees, it doubtless does great service. It beats for its food in the trees, and it is probable that its peculiar feet, long wings and tail, and soft plumage, enable it to hunt among the leaves, in places where other insect-eating birds cannot reach. Judging by the young bird, the cuckoo is a ravenous eater; for it requires more labour to feed a single one of them, than to raise a whole brood of the species into whose nests they intrude.

The BEE-EATER is so rare a bird in England, that it can scarcely be considered British. It is most gorgeous in the richness of its colouring; brilliant, in blue and green shades, and tinged with beautiful iridescent hues. It is about the size of the thrush, and takes its food on the wing, living: chiefly on winged insects, particularly those of the bee kind. In Egypt this bird is called "bee'senemy."

The HOOPOE is a singular looking, but very beautiful bird, and comes a straggler to our isles; occasionally breeding here, but disappearing at the end of the summer. It finds its food somewhat as the creeper and nuthatch do; and builds 
in holes of trees, or of rocks. The most remarkable characteristic of this bird's appearance is its crest, consisting of two rows of orange feathers, tipped with black; usually falling backwards on its neck, except when the bird is surprised or irritated, and then it stands erect.

The KINGFISHER, or HALCYON, rivalling, if not exceeding, the beauty of the bee-eater in its plumage, is also much more common. Most of us may have seen it, shooting meteor-like across a brook; - a bright green line alone seeming to mark its course. It has been compared to a gleam of a broken rainbow, darting along near the surface of the waters; and indeed, one is almost at a loss whether to think it a meteor or a bird, and when seen, as it perches on some slender twig overhanging the water, it resembles the gay flower of a rare and curious water-plant.

This bird fishes wholly by the sight; and as his prey is small, he requires to see it very clearly; hence, it is only at particular spots, and in peculiar states of weather, that he can carry on his operations with success. The water must be clear and smooth, the atmosphere most transparent, and the surface of the brook glassy. These are genuine " halcyon days," on which the kingfisher is out and active; and hence the wondrous powers ascribed to this bird by the older naturalists and poets, 
who believed that it had marvellous influence in quelling the storm, and subduing the tempest's rage.

"—_May halcyons smooth the waves, and calm the seas."

The kingfisher nestles in some hole in the bauk, where, having seized the favourable occasion to obtain an abundant supply of food, and gorged himself to the very throat, he retreats, and dozes and digests. To this place he continues permanently attached, and is not to be driven away from it, even by the plundering of his nest. The young birds are very clamorous for food, and consume a large quantity. They have been taken from the nest, and brought up, being supplied with small fish; and their powers and modes of proceeding have never failed to interest the observer. The stronger will kill the weaker, even to the last bird, unless care be taken to separate them.

The PARRoTs are an extensive family of true climbers, divided into numerous sections; but as none of them inhabit our country they do not come within our limits, and they are merely mentioned for the purpose of saying that in "'The Zoologist, for 1855," there is an interesting account headed, "Parrots at large in Norfolk;" stating that in a wood in the neighbourhood of Cromer, there are living thirteen American par- 
rots, (two of the Amazon, and eleven of the Carolina breed,) entirely at liberty, but fed at regular hours, much in the same way as pigeons. They are very hardy, and remain abroad all day, and, during the summer, at night also; in the winter sheltering within doors; though even in the severest weather flying abroad for at least a part of the day. During the autumn, they feed themselves entirely on beech-nuts and acorns. They are described as very tame and sociable, and much improved in health and plumage since they have been allowed to go at large.

Mr. J. H. Gurney has communicated to the same periodical, a very curious incident observed by himself, while visiting the Zoological Gardens, in Regent's Park, in 1850. He saw inhabiting the same cage, a very large white cockatoo and a much smaller green parrot. The parrot being offered a nut, took it; but, without endeavouring to crack it himself, he immediately carried it to the cockatoo, and transferred it from its own bill to the more powerful one of his neighbour, who fortnwith cracked it, and then divided the kernel; swallowing half himself and honestly returning the remainder to the parrot. This was repeated at leasi half-a-dozen times. 


\section{ORDER III.-RASORES. \\ SCRAPERS, OR POULTRY TRIBE.}

CHAPTER I.

The Galitnaceous Birds, or Poultry tribe. PigeonsEnblems of Peace and Love-Held sacred among the Russians-One of the largest and most generally diffused of all birds-British doves-Their habits and food-Four British species-The Ring-dove-The Stock-dove-The Rock-dove-Effect of music on a Pigeon-Description of this bird in the Isles of the Hebrides-The Turtle-doveCountless multitudes of the Passenger-pigeon in America -M. Audubon's account of a vast flock of them-Domestic Pigeons and their varieties-Instances of power of speed in the Carrier-pigeon-A flight of three thousand miles.

WE have now arrived at the third order of birds, (the RASORES, SCRAPERS, or GALLINACEOUS birds,) most of which obtain the principal part of their food upon the ground. Among them are found those most useful to man, especially in a domesticated state.

The PrgEONs, as they resemble, in some respects, the perching birds, have been placed in immediate succession to them.

These birds have universally attracted the attention of man; and been chosen as emblems of all that is gentle, loving, and virtuous. "It was a dove (ever since sacred to peace) that 
brought the olive-branch to the ark of Noah; for which she has her place among the constellations of heaven; and the dove, in mystic emblem, shadows forth the Comforter, the Holy Ghost."

There are some qualities peculiar to them, which seem to justify this interest. Pigeons of all kinds are supposed to be especially faithful in their loves. The pair evince a mutual attachment and fidelity, which (notwithstanding their disposition to flock) we have reason to believe they preserve through life. Their apparent fondness for each other,manifested by saluting with their bills, and murmuring (or cooing) notes of pleasure; their habits in tending their young; combined with the beauty and grace of their appearance, and the soft plaintive sound of their voices, all unite to give them a special interest to the lover of nature, and are suggestive of innocence, purity, and tenderness. Accordingly, we find that doves were sacred among the priests of antiquity; and in the present day the same feeling in favour of these creatures is observable in many countries. A writer in the fourth volume of "The Naturalist," says, "The common pigeon swarms in the city of Petersburg and the country: it is esteemed sacred, and called God's bird by the Russians, from the circumstance of the Holy Spirit assuming that form when descending upon our Saviour. To kill and 
eat it, is considered an act of profanation. I had one day an opportunity of observing, myself, how the respect for the pigeon prevails amongst the lower orders. I shot six away from a village, at one shot, and brought them home with the intention of making a pigeon-pie;--when I threw them on the table, a Russian servant who was near, after several ejaculations against my impiety and cruelty, snatched up one of the dead birds, and, bursting into tears, commenced kissing and fondling it."

These beautiful birds abound in most of the temperate and tropical regions of the earth, being, however, far more numerous and more gorgeously attired in the latter, where they sometimes literally realize the beautiful picture given by the psalmist;- "As the wings of a dove covered with silver, and her feathers with yellow gold!" The genus "Columba" is, indeed, one of the largest and most universally diffused of all the feathered tribes; being found in all quarters of the globe, and almost every island of the sea. Our British groves are made musical by its voice.

"Where, o'er his own sweet notes, the ring-dove broods."

Doves feed more exclusively on vegetables than almost any other birds. They do not even feed 
their young on insects, as many do. They are provided with the means of adapting the food they eat to the tender stomachs of their fledglings.

All birds which feed much on vegetable matter, have a portion of the gullet capable of enlargement, so as to hold a considerable quantity of food; this is called the craw, or crop. In doves, there is a peculiar substance secreted in the crop, in appearance not unlike curd, and somewhat answering to milk in quadrupeds. This is mixed with the food given by the parent birds to their twin brood (for there are but two, usually a male and a female) not, as is usually done, from the bill; but they put their own beak fairly into that of the young one, and force up and deliver the already half-digested food, by a peculiar action of the gullet. But, though these birds are principally vegetable eaters, they also pick up insects and various kinds of snails, which they swallow, generally shell and all. They are partial to salt.

We have four species of dove found wild in Britain. The RING and the sTock nove are both resident inhabitants of the woods. The ROCK DOVE dwells in rocks, near the sea; and the TURTLE DOVE is a summer visitant of the woods, and found only in some localities; the latter being the only true Dove (scientifically) as distinguished from the PIGEONS. 
The RING DOVE is considerably the largest of the order, and is most generally distributed over the country. It takes its name from the circle of white feathers round its neck, and is also called the wood-pigeon, the cushat, and the queest-the last name having reference to the plaintive tones of its voice. It may be heard, almost incessantly, in the months of March and April, in thick woods and plantations of fir-trees, in which it delights to build. It commits serious ravages on most kinds of agricultural produce, especially peas. Between seed-time and harvest flocks of these birds are seen, half-buried in the long grass of pastures, foraging for food. When the wheat is in ear, they are terribly destructive, settling down on the corn, and picking out quantities of the milky grain. In winter they attack the field-cabbages and turnips; and in spring, the clover fields, picking out the "eyes," or central leaves of the plants.

Overlooking these pillaging propensities they are pleasing and ornamental inhabitants of our woodland districts; and no sounds are more soothing than the low, soft, plaintive notes of the males, as they may be heard serenading their mates in some fine old wood during the tranquil calm of the summer's evening.

The whole form and appearance of this bird is 
fine, combining elegance and vigour; and the colouring of its plumage is also beautiful. Like the pigeons, generally, it has great powers of flight; in cold weather flying in flocks, sometimes consisting of hundreds, feeding in company during the day, and roosting at night in thick plantations of high trees. They are in considerable estimation as an article of food, and much pains have been taken to domesticate this species; but in vain, the bird will not breed in a dornesticated state, nor live in it, unless by force.

The stock Dove is a smaller species than the ring-dove. It inhabits woods, but is a less numerous species; it is a roaming bird, and migrates in large flocks. Its note is a low rumbling sound, quite unlike the cooing of the preceding one. It builds in the hollows of old trees; and not unfrequently makes its nest in holes in the ground; sometimes selecting a rabbit's burrow for the purpose.

The Rock Dove is the species from which our domestic pigeon, with its numerous varieties, is descended. These birds choose high cliffs and recesses of the rocks to dwell and nestle in, and never perch on trees. They are met with in England; but are limited to particular parts of the coast, and nerer come inland. Hambro' Head, and a few similar localities, are their only 
British habitats. Their food consists principally of grain and seeds, and they also eat several species of snail shells. There is a proverb which says, "whiten the pigeon-house, and the pigeons will come;"-meaning, that by cleanliness and good housewifery friends are drawn to you. It is, however, literally true, that a whitened pigeon-house is preferred by the birds. The reason for this is supposed to be that they like the lime, which is useful to them, their eggs being composed partly of carbonate of lime, and it is for this substance, doubtless, that they generally frequent chalk cliffs.

A singular anecdote of the effect of music on a pigeon, is related by John Lockman, in some reflections concerning operas prefixed to his musical drama of Rosalinda. He was staying at a friend's house whose daughter was a fine performer on the harpsichord, and observed a pigeon, which, whenever the young lady played the song of " Speri-si," in Handel's opera of Admetus, would descend from a neighbouring dove-house to the window of the room in which she sat, and listen to it, apparently with the utmost attention and pleasure. When the song was finished, the bird always returned immediately to the dove-house, paying no attention to any other music which was played.

Whether on the rock or in the pigeon-house, 
thesse birds are gregarious, flocking together all the year round; and to whatever distance they may range during the day, they invariably return at night. Very wonderful is the instinct which enables these creatures, notwithstanding the height at which they fly, their passing over the sea where there are no marks to guide their course, and all the extent and variety of their range, to return with such unvarying certainty to the place whence they set out.

He who would see this dove to perfection, must go to nature's own pigeon-house among the cliffs and waves of the Hebrides. "There," says Mr. Mudie, "on some glittering day, when the meridian sun lulls birds and breezes into repose, you row swiftly but silently into the portal of some giant cave which rises aloft toward mid-heaven; and while you are contemplating silent nature, the rowers suddenly lift their oars, and dash them against the sides of the boat. The echo is lond; but the sound of the wings which it wakens into action is louder still; it is as though the hollowed and craggy isle were falling to pieces about you, and the wide Atlantic were heaving and vibrating to its most distant shore."

The TURTLE DOVE is the smallest British species. It is a summer visitor, arriving in May, and departing at the approach of autumn. It is not 
generally diffused, and is said to be most abundant in the thickly-wooded parts of Kent. This species utters a peculiarly plaintive, even mournful note; and in addressing his mate, the male makes use of a variety of winning gestures, cooing at the same time in the most soothing and gentle accents. Hence it has been ever regarded as the perfect emblem of connubial attachment and constancy.

In reference to the peculiar character of its voice, sportsmen, while they speak of a flight of pigeons, also say, a dule of turtles, a term derived from the Latin word doleo, to mourn.

These are all the native pigeons of our isles. Few persons have any idea, from what they see of these birds here, what is their countless increase and abundance, in other parts of the world. The grand places for them are between the Oriental Archipelago and New Holland, and between the northern and central parts of America. The most startling accounts are given of the myriads of them often beheld in North America, especially of the species called the passenger, or migratory pigeon.* Flocks extending miles in length, and for days together, have been known to pass over the hills during the spring from the southward. M. Audubon the great American

* This species has been killed in England, though very rarely. 
ornithologist, in describing what he himself witnessed, confesses that he can scarcely believe what he relates is fact.

He was travelling in 1813, when he came into the track of an immense flock; "While I travelled on (he says) I met still more as I proceeded. The air was literally filled with pigeons; the light of noonday was obscured as by an eclipse; the dung fell in spots, not unlike melting flakes of snow, and the continued buzz of wings, had a tendency to lull my senses to repose." Heaven has wisely and graciously given to these birds rapidity of flight and a disposition to rango over vast tracts of the earth, otherwise they must have devoured the whole produce of agriculture or perished in the districts they inhabited; and thus we have exemplified the truth of the Psalmist's words, "The eyes of all wait upon thee; and thou givest them their meat in due season." "*

Domestic Pigeons are a study of themselves; the principal ones are the barbary, the biset, the carrier, the crested, the helmet, the horseman, the jacobine, the laced, the Norway, the rough-footed, the shakers, the smiter, the spot, the tumbler, the turbit, the turner, besides a countless number of mixed breeds.

Of these the carrier is the most deserving of * Psalm lii., cxlv. 15. 
notice, having been made use of in very early times, as the means of conveying intelligence. The historian Diodorus Siculus above two thousand years ago speaks of them as being employed for this purpose. And about five hundred years since relays of carrier-pigeons formed part of a telegraph system adopted by the Turks.

Many examples of power and speed in these birds, and of the certainty with which they return from incredible distances to the place where they were bred, are on record. These wonderful powers have been made use of both in war and commerce, and the most extraordinary instance we know of is that of a carrier-pigeon despatched by Captain Sir John Ross from his winter quarters in 1850, which actually reached its home near Ayr, in Scotland, in five days. Sir John took with him fuur of these pigeons belonging to a lady residing in Ayrshire, intending to liberate two of them when he should go into winter quarters and the other two when he should have discovered Sir J. Franklin. A pigeon made its appearance at the dovecote in Ayrshire, on the 13th October, which the lady recognised by marks that left no doubt on her mind of its identity. It bore no billet, but there were indications of one having been torn from under the wing.

Lieutenant Osborne, in his "Stray Leaves from 
an Arctic Journal," gives the details of the despatch of these birds from Assistance Harbour. The opinion prevalent in the squadron was that the poor little creatures would be frozen to death, as the wind was blowing fresh from the north-west and the temperature below zero. The two birds duly freighted with intelligence were put in a basket which was attached to a balloon in such a manner, that after the combustion of a certain quantity of match the pigeons would be launched into the air to commence their flight. In about a hundred and fifty hours one of the two, as verified by the lady, reached its home. This marvellous flight of three thousand miles is the longest on record. Of course it is unknown how far the bird was carried by the balloon, and when or where liberated; which would depend on the strength and direction of the gale by which the machine was carried along.

As my readers may probably like to have the "latest news" of the pigeon world, I will give them the history of a "pigeon express" that carried the news of the capture of Sebastopol to Colombo the capital of Ceylon.

This town is situated seventy-two miles from the port of Galles, at which the steamers touch. About five years ago the idea was originated of employing carrier pigeons to bear despatches from 
the coast to the seat of government; and from that time to the present these messengers have continued to perform the office assigned to them. The road being almost a straight line, the birds usually accomplish the passage of the seventy-two miles (well laden with manuscript and printed slips) in from one to two hours. As soon as they arrive a special flag is hoisted to announce the event, and every one hastens to the office to hear the overland news.

It may be well supposed that the war intelligence had been most eagerly awaited; and when the despatch announcing the details of the fall of Sebastopol-so full of joy and grief for inultitudes -reached the capital of the distant colony of Ceylon, great was the excitement. Orders were immediately issued by the commander-in-chief, for a royal salute to be fired in honour of the event, which was done accordingly on the faith of intelligence transmitted by no more regular channel than the carrier pigeons of the Colombo Observer office.

The natives of Ceylon quite appreciate the value of these news-bearing birds, and when occasionally the pigeons go astray, driven out of their course by a strong wind, or bewildered by rainy or hazy weather, they are almost invariably caught and sent to the Observer office by the people. 
The mode in which the despatch is fastened to the bird is this; - the paper is rolled tightly to about the size of a quill; it is then doubled up and tied round with thread, a loop being left through which a piece of soft. cord is run. The cord is then tied gently just above the claw, and the despatch hangs down. It cannot slip off; and the instant the bird is let go, both leg and despatch are drawn up under the plumage, and the document is so perfectly protected from the weather, that even the heaviest rains of the tropics through which the birds occasionally have to pass, scarcely affect the paper.*

*In the "Illustrated News," for February 2nd, 1856, this account is given, together with a picture representing the scene on the reception of the Pigeon Express bringing the news of the capture of Sebastopol at the capital of Ceylon. 
SCRAPERS; oR, POULTKY TRIBE.

CHAPTER II.

The Pheasant-Its origin-Naturalized in England and protected by law-Food and habits of this bird-Pugnacity of the Cock Pheasant-Account of the "crowing" of Pheasants - The Ringed Pheasant - The Golden, the Silver, the Argus, and the Impey Pheasant.

The pheasant. This splendid, well-known inhabitant of our woods is generally supposed to have come originally from the banks of the Phasis, a river of ancient Colchis, which falls into the easternmost part of the Black Sea; but the time of the introduction of this bird into our island seems to be quite unknown. It is now extensively spread throughout the greater part of Asia and Europe. With us it is naturalized and generally distributed over England, but is rare in Scotland. Its favourite haunts are woods, where it is a more than half-tame bird; and indeed it comes like our barn-door fowls at all hours of the day to be fed, and where not disturbed, roosts in trees close to our habitations.

By the laws of England the pheasant is considered "game," and sportsmen must take out a 
licence from government to be permitted to shoot it. Its preservation is considered to be owing to the vast care and expense bestowed upon it by our great landed proprietors, by whom it is held in high estimation not only on account of its beauty but also because of its interest to the sportsman. At the same time the price it commands as an article of food makes it a tempting object to the lawless pursuit of the poacher.

The pheasint commences laying in April, and hatches its young towards the end of May. Its principal food is grain and seeds, and it is fond of acorns and various berries and green plants. Mr. Selby mentions that the root of the common buttercup is much sought after by the pheasant, and forms a great portion of its food during the months of May and June. Boiled potatoes and beans are the best nourishment for it in the winter.

These birds have certain habits which make them an easy prey to the poacher. The neverfailing morning and evening notice which they give by their crowing and whistling discover their roosting-places. They are also in some respects stupid birds, and on being roused will often perch on a neighbouring tree and fix their attention so wholly on the dogs that the sportsman may approach very near without observation. 
But old cock-pheasants are said to "gain wisdom by experience," and to have recourse to many stratagems to effect their escape when they find themselves to be pursued. The hen appears to trust to her quiet brown-hued plumage to shun detection, and she will squat in any bit of long grass that is near at hand, often surprising and startling the young sportsman by bouncing up with a whirring noise close against his feet, and not unseldom owing her safety to this fact.

The ordinary weight of a male pheasant is about two pounds and a half, but when well preserved and highly fed they have been known to exceed four pounds. They are then plumper and fatter than barn door fowls, and exceedingly rich in plumage. Mr. Warburton makes this complaint against his pheasants-that they deprived him of the gratification he used to enjoy in listening to the lively chirp of the grasshoppers ;- " they have completely exterminated this merry charmer in my park," he says.

The pheasant sometimes becomes extremely pugnacious in disposition, as the following facts will show. Not far from a large wood there was a farm-house at which game fowls were kept, who roosted at night in an oak tree close by the borders of the wood. One morning the cock, a fine young bird, was found under his perch dead, 
considerably beaten, his plumage ruffled, and his feathers smeared with blood. An older bird of the same breed was procured to take his place, who soon shared the same fate, and a third also. At length the owner of the fowls, vexed at these repeated losses, and unable to account for them, bought a large, strong, courageous bird, and armed him with sharp steel spurs. Next morning, beneath the oak tree, there was found lying dead, not the cock, but his vanquished foe, a large, well fed, old cock. pheasant.

Mr. Knox, in his "Garne-birds and wild-fowl," gives the following striking account of the "crowing" of pheasants. "The habit of crowing, indulged in at all hours of the day during the breeding season, is not restricted to the purposes of love or the hour of rest. The same note is uttered on quitting the perch at early dawn; and the sound of thunder or distant cannon never fails to produce it. How often have I heard it elicited by the booming of the Portsmouth guns, though at a distance of thirty miles, when the weather was calrn or the wind in a favourable quarter.

But the most remarkable instance of this kind that ever came under my notice occurred on the 11th March, 1850. It was a clear sunny day, the air cold and frosty with a gentle breeze from the north-east. I had been riding through Charlton 
forest and had just begun to descend the northern slope of the downs by a rugged path above the village of Graffham, when I halted a moment to admire the magnificent panoramic view that here suddenly bursts upon the sight. I had not gazed long, before a deep, hollow booming, or protracted concussion (for it was rather felt than heard) shock the earth for some seconds. At the same moment a pheasant, in an adjoining copse, announced his consciousness of the shock by a sudden crowing, which had hardly ceased before a second explosion, succeeded after another interval by a third, the loudest of all, induced every cock-pheasant in the woods of Lavington to sound his note of alarm. On my way home I passed several persons who had heard the noise and had noticed its effect upon the pheasants, especially one party of labourers working close by a large preserve, who told me that a loud and long-continued.crowing proceeded from all parts of the wood for many minutes after the last explosion. No one was able to conjecture the cause of the sound, nor was the mystery explained till the following day, when intelligence arrived of the awful explosion at Messrs. Curtis and Harvey's powder mills at Hounslow, nearly fifty miles distant in a direct line from the spot where I heard it."

Besides the common pheasant, there are several 
other species; many of them of splendid plumage, and all of them natives of Asia, except one, that has been recently discovered in Southern Russia.

The RINGED PHEASANT, is found in our parks, and preserves of game, and is a native of China, and of the districts round the Caspian Sea. Its chief characteristic is a white ring, encircling the middle of the neck.

That beautiful species, the GOLDEN PHEasant, has, hitherto, only been preserved in aviaries, where it is sheltered from cold, and supplied with food. It breeds freely in captivity. It also is a native of China, and is frequently seen faithfully represented in Chinese drawings; and is called by the natives "Kinkee," which means, "gold-flower fowl."

The sILVER PHEASANT, is a much larger, and more hardy bird than the preceding; and is a native of the north of China. This bird might, probably, be naturalized in our country. It is very tame, and has more of the manners of the fowl than pheasants in general.

That far-famed species, the Akgus PHEASANT, has never (it is believed) been brought alive to Europe. This noble bird is little inferior, in size to a turkey; its greatest beauty is in its remarkably long and broad wing-feathers, which spread out at their extremities, and altogether, 
form a large, sweeping, fan-like plume. Each of these feathers is ornamented with a row of eyes, whence it takes its name. The bird is a native of the south-east of Asia, and the island of Sumatra.

The IMPEY PHEASANT, is another species, renowned for the beauty and richness of its colouring. It is a native of the Himalayan mountains, and is never found on the plains. The plumage is of intense metallic brilliancy. 
SCRAPERS; OR, POULTRY TRIBE.

\section{CHAPTER III.}

Grouse. The Capercailzie, or Cock of the Wood-Description of this bird in his native Norwegian forests-The Black Grouse-Inhabits the Scotch hills-Courage of the female in defence of her young-The Red Grouse, or Moor-fowl-An 'exclusively British Bird-Inhabits the Highlands of Scotland-The Ptarmigan, or White Grouse -A hardy mountaineer-Numbers imported from Lapland and Norway, for sale-Linnæus's account of the Ptarmigan in Lapland.

OF GROUSE, we have four kinds: the noble CAPERrAILZIE, or COCK OF THE WOOD, was formerly abundant in the mountainous forests of Scotland and Ireland; and, after having been extirpated for more than half a century, it has been recently restored in one district of Scotland. Its re-introduction was effected by the late Sir T. F. Buxton, who sent his gamekeeper to Norway for it, and presented the birds which he brought over to the Marquis of Breadalluane.

This is the great game-bird of the North; essentially an inhabitant of the forest, delighting in the pine-forests of Scandinavia and other pinegrowing districts of northern and eastern Europe, and feeding on the leaves and tender shoots of 
the fir-trees. There, amid the branches of the mighty pines, he sits, generally roosting in the trees at night; but if the weather be very cold, he not unfrequently buries himself in the snow. Considering the large size of the bird, which is equal in bulk to a turkey (weighing from 8 to $10 \mathrm{lbs}$, or even more), his flight is not particularly heavy or noisy.

There is an admirable account of the habits of this noble bird in Mr. Lloyd's "Field Sports of the North of Europe," and in "The Zoologist, for 1850," the Rev. A. C. Smith, has contributed a few interesting extracts from his journal on this "pride of the Norwegian forests." He says :-

"The birds inhabit the thickest parts of the forests ; and difficult, indeed, is the ground which the sportsman has to traverse in pursuit of them; generally among fallen trees, and huge masses of rock, and uptorn trunks, and tangled brushwood, the capercailzie loves to dwell. The old cock is a wary and cunning bird, and, as though knowing that his great bulk presents a larger mark for the sportsman, and is more difficult to conceal among the trees, he will run in advance of you through the forest, till he is far beyond your reach."

The native sportsmen are so well aware of this, that it seems they have recourse to art in order to secure their game. They lie in wait in the forest, 
during night-time, till early dawn, when the capercailzie, perched on the top of a pine-tree, commences its "song,"-a harsh, grating sound, which may be heard at a considerable distance. While thus engaged, the poor bird seems absorbed with its own music, and has no eyes or ears for anything else. Seizing this moment, the sportsman hastens as speedily as possible towards the place; but in a minute or two the singing ceases, and the instant it does so, he must stop wherever he be. In a few minutes the singing is sure to commence again, and then he may approach still nearer his victim. Thus he proceeds, till he gains at length the foot of the tree where the bird is perched, and then, while the poor unconscious fowl is delighting itself, a cool steady shot from below, brings him down with a tremendous bounce, and the sportsman's bag is at once filled, for the bird is as large as a turkey.

The BLACK GROUSE is so called from its violetblack plumage. It has a white bar on the wings, and the tail is very much forked. The weight of the male bird is from three to four pounds. These birds are most abundant in Scotland, and the northern parts of England, and occur sparingly in a few wild localities of the south. They inhabit the lowest slopes of the hills, lonely heaths, and the banks of marshes, but come on 
the stubble-fields in winter, when these are near their haunts. They feed on wild berries and the seeds of wood or marsh plants, and the tops of heath and birch.

In spring, the males are alert by early dawn, crowing and uttering a harsh and grating sound, like the whetting of a scythe, displaying the beauties of their plumage, and often fighting most desperately till each has secured his share of mates, when they scatter themselves, and the business of incubation commences. This labour is left to be performed by the female, and on her alone devolves the care and provision of the brood. When the young are all hatched, she leads them to new pasture, and returns no more to the nest, but gathers them at night under her wings. Instances have been known of the grey hen (for so the female of the black grouse is called), showing great courage in defence of her offspring. It is mentioned in "The Zoologist, for 1855," that a gentleman being on a fishing excursion, crossing the hill between Carr-bridge and the Spey, observed a dog, which was with him, pointing, when a grey hen offered to do battle in defence of her brood, flapping her wings like fanners, and, with heroic bravery, she actually beat her canine antagonist, and to the no small wonder of the beholders, drove him, crest-fallen, away. 
Another instance of remarkable instinct in this bird occurred in the same neighbourhood. In those districts the herd-boys are paid to preserve the nests and protect the birds. One of these boys told a keeper lately, that he had no difficulty excepting with one nest, which was in a place much frequented by cattle. "But (he said) I have built a little house of stones and turf, and that will prevent the cattle from getting at it." The keeper objected that he would certainly scare away the bird. "Oh! no," he replied, "I have left a little door for the hen to get in and out at, and she sits as usual." The keeper, on visiting the place, found this to be actually the case, and many persons witnessed the curious fact.

The supply of black grouse to the London poulterers is very large and continuous, from the end of August till the following month of April ; during the first four months, from Scotland, and afterwards, from Norway and Sweden.

The RED Grouse, or moor-fowl, is the bird thus described by Burns :-

"The moorcock springs, on whirring wings, Among the blooming heather."

And these lines are very descriptive of the flight of the bird, which is low and peculiar, and apparently performed with considerable effort. This 
is the only exclusively British bird which we can boast of, being found in no part of the world except the British Isles. It is of a reddishchestnut colour, shaded with brown and black. It exists in England and Wales, and the north of England as well as Scotland and also in Ireland; but the great stronghold of the species is the Highlands of Scotland, where its preservation is carried to such an extent, and the rights of shooting let at such high rents, that despite the immense annual slaughter, in the early part "of the season, there seems to be no prospect of its extermination, or even material reduction.

The red grouse pairs very early in the season, and commences laying in March or April. Its favourite cover is the heather, which preserves the birds from the weather, and from enemies. Its food is berries, and the tender tops of heaths. Mr. Mudie says, it is probable that the superior juiciness and flavour of the red grouse, is owing to their having a greater proportion of insect food, and their feeding in drier places, as it is a fact, that insect-feeding birds are always sweeter than those which live on vegetable substances only; all gallinaceous birds are finer flavoured in dry seasons than in rainy ones.

At the first part of the shooting season the young birds lie close, particularly where the heath is 
high and strong; affording excellent sport after a favourable breeding season; but as the year advances, the birds get strong, and from being disturbed, become wild, and uniting in packs, it is very difficult to get shots at them. The weight of this grouse is about twenty-four ounces.

The ptarmigan, or white grouse, is the smallest in size of the British grouse. It is now only to be found on the highest summits of the lofty ranges of mountains in the central and northern parts of Scotland, and on some of the western isles. It is said to have formerly existed in Wales, but half a century, at least, must have elapsed since its occurrence in that principality. Its haunts are among the snow-covered peaks and bleak rocks far above the heathery regions inhabited by the grouse.

It is a very interesting bird, both from the peculiarity of its haunts and its habits. Although much less abundant than the red-grouse, it does not seem to run any risk of extermination, for the inaccessible nature of its retreats, puts it beyond the reach of the sportsman, who is not tempted to incur the necessary fatigue by the chance of any other game; excepting, indeed, the grey hare, which seems to share with the ptarmigan these inhospitable regions. By the same means it is protected from animals of prey, as it is above the 
range of fox, mountain-cat, and martin, and of its four-footed enemies in general.

The bird is in every way adapted for the situation it inhabits; being compactly and firmly built, and its feet and toes, down to the very claws, are so completely and closely feathered that they are proof against almost any degree of cold. The bill is black and strong (black bills and claws always are firmer than those of any other colour), and well adapted for crushing the hard berries, heath-tops, mosses and lichens on which it feeds. Nature-or, rather, the God of nature,-has provided this bird with an additional safeguard in the tints of its plumage. In summer they are a mixture of black and yellow, white and grey so exactly resembling the mossy lichen-covered rocks and stones among which it lies concealed, that only the practised eye can detect it. As the season changes, its hues gradually become whiter, until at last it becomes like the snows of winter.

During that season the ptarmigan congregate in family parties. The packs live peaceably together, and shelter themselves in holes in the earth or snow, through which they contrive to scrape down, till they can subsist on the scanty vegetation which it covers. For, true to the mountaineer's instinct, this mountain-bird is the last to quit his home, be it never so barren, and not even winds 
which might uproot forests, and frosts which all but congeal mercury, can drive him thence.

Most people have noticed the vast numbers of ptarmigan which are found in the shops of the dealers, during the latter part of winter and the early spring. Perhaps few are aware that scarcely one of them has been killed on the mountains of Scotland. They are imported from Lapland and Norway, particularly the latter country, where they are exceedingly plentiful. The weight of a full-grown bird is about a pound and a quarter.

There is a second species of ptarmigan in Norway and Lapland, and Linnæus in his Lapland tour met' with both kinds. Under date of July 30th, he says:- " The little alpine variety of the ptarmigan* was now accompanied by its young. I caught one of these, upon which the hen ran so close to me, that I could easily have taken her also. She kept continually jumping round and round me; but I thought it a pity to deprive the tender brood of their mother, neither would my compassion for the mother allow me long to detain her offspring, which I restored to her in safety." We cannot help admiring the gentle and loving heart of the great naturalist, as it shows itself in this pleasing little incident.

* The Scotch ptarmigan is the saine as the smaller Norwegian species. 


\section{4}

SCRAPERS, OR POULTRY TRIBE.

\section{CHAPTER IV.}

The Common Partridge-Its food and hatching-timeTame Partridges-Two anecdotes illustrative of attachment in these birds-The Partridge a friend to the farmer-A family of Partridges-Instinct and affection of parent birds - Hill Partridges-Advice to sportsmen-The Red-legged Partridge - Reasons for the sportsman's dislike to this bird.

The Common PARTRidge is so well known that little new can be said about it, as we are all familiar with its appearance and habits. It is abundant in all cultivated parts of Great Britain, but seldom found at a distance from arable land, which is its favourite haunt. It feeds on grain, seeds, and insects, and especially on the eggs and larvæ of ants. It is the most prolific of all the wild gallinaceous birds, the eggs being often as many as twenty, and never fewer than twelve. The period of hatching is twenty-one days, and the grand hatching-time in the south of England is from the 20th of June to the end of that month. Among our native game-birds there is not one more essentially a wild creature than this; and yet there is none whose increase and welfare have 


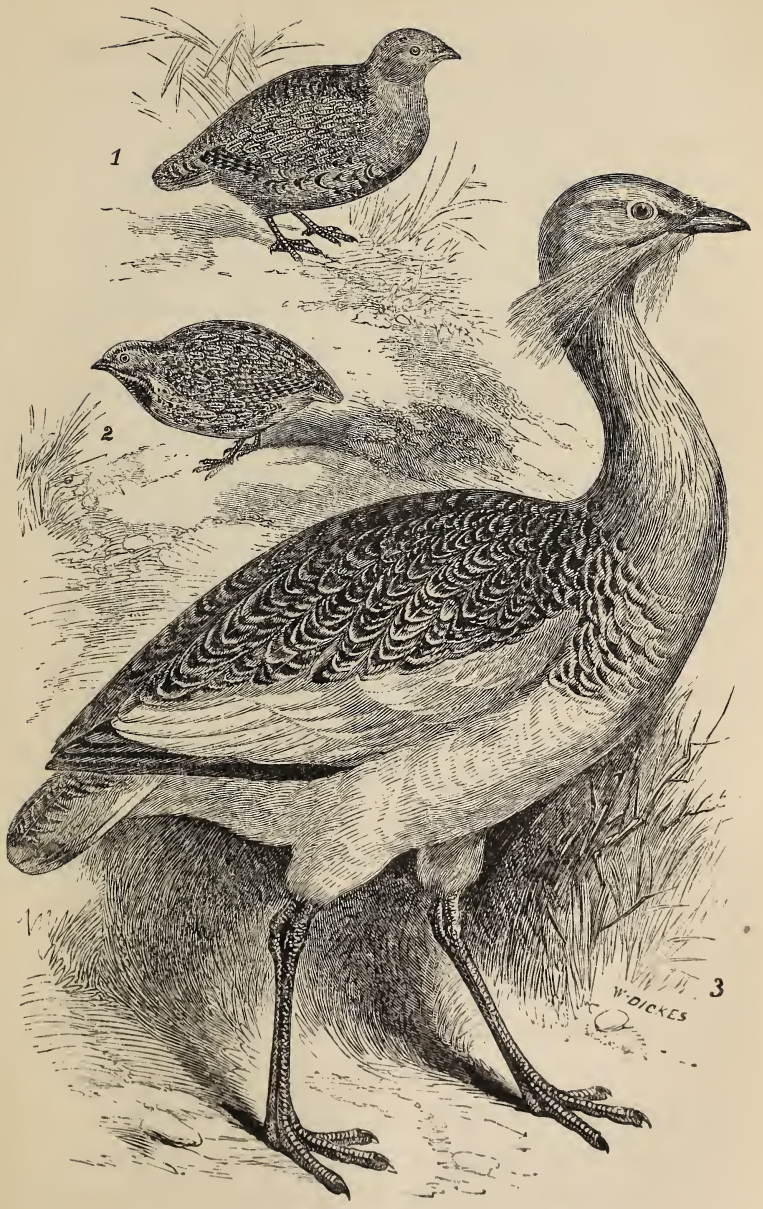

1. Partidnge. 2. Quail. 3. Great Bestard. 

been so much favoured by the improvements in modern agriculture, "the districts best cultivated, and producing the most corn," says Mr. Yarrell, "frequently also producing the greatest number of partridges."*

And yet, though such be the case, there is scarcely an instance of the partridge having bred in captivity, though individual birds are easily tamed, and have been known to evince the strongest personal attachment to their owner. A striking instance is given by Mr. Knox, in his "Game Birds and Wild Fowl." He says that a lady in West Sussex had a tame partridge for many years. It was a mere chick when she first possessed it, and no dog or parrot was ever more tame or docile. Though it had the range of the house, its favourite place was the drawing-room, where it would sit for hours, on the back of the chair usually occupied by its beloved mistress, and showed the strongest uneasiness during her occasional absence. When she retired to rest it accompanied her to her chamber, and took up its post near the head of her bed. Unhappily this interesting bird met with the usual fate of pets, and came to an untimely end.

In the year 1854, a nest of partridges' eggs was

* This is not always the case. In Norfolk the partridges have diminished in number by improved farming: 
brought up under a hen; the young brood exhibiting the greatest tameness and familiarity. To the woman who fed them they showed a particular partiality, and would come at her call, and follow her about, close at her heels, nor leave her, so long as she remained in the garden, where they were kept. If not attended to as usual, they would come and peck with their beaks at the window of the room she sat in, and from which they were usually fed. As the season advanced, several of them strayed away; but four remained constant up to the month of August, until at length they too disappeared for a day and a half, and it was supposed had quite departed. However, on the afternoon of the second day a tapping at the window was heard, and there were the four partridges again. The mistress opened the sash of the window, when they immediately flew up at her, and fluttered about her face and breast, in an unusual manner. Then, alighting on the ground, they merely picked a few grains of the corn she threw to them, and flew away. It was evident they had not come for food; it was a farewell visit, just to say "Good-bye! thanks for all your kindness; we are now off." They returned no more.

The partridge is decidedly a friend to the farmer, probably as much so as the pheasant. His 
consumption of grain is less, and the quantity of noxious weeds and insects devoured by him at all seasons of the year is great.

There are few more interesting sights than a family of partridges. In the day they keep together, and are seldom seen on the wing, unless disturbed. They frequent grass fields, preferring the hedgesides. They feed only in the morning and in the evening, and bask during the heat of the day, or dust themselves in dry spots, where the soil is loose; the young and weak birds being often much troubled with parasites. As soon as the evening meal is over, and the insects begin to buzz, their call is heard, and off they move to some spot where they "jug," or roost, for the night, nestled close on the ground, in a cluster, keeping their heads outwards, and tails to the centre. Some covies occupy the same spot, if not disturbed, for a fortnight or more; and others change their quarters every night.

The attachment of partridges to their young is proverbial. Both parents lead them out to feed, and assist them in procuring food by scratching the ground with their feet. They frequently sit close together, and cover the young ones with their wings; and from this situation they are not easily roused. But most persons know if they be disturbed what ensues. The male utters a cry of 
distress, and throws himself in the way of the intruder, and by every stratagem endeavours to attract attention from the young, so as to give the female time to carry off the brood in safety. Many are the notes and records of the cunning and ingenuity shown by them on these occasions. One female, being surprised on her nest, when she had laid only four eggs, was evidently aware that she had been discovered, and covered the nest very carefully with dead hedge-leaves and dry twigs, which she removed every morning to deposit an additional egg, afterwards concealing them again in the same manner; and so artfully was this done that none but an experienced eye could have known it from an unused nest of the former year. This occurred in 1840. The same person who witnessed this case, says that one day in August 1844, he surprised a covey of young partridges, when one of the parent birds, in the most bold and determined manner, refused to quit the spot for some time, and actually made an attack upon his legs. Mr. Jessie says : "A farmer discovered a partridge sitting on its eggs, in a grass field. The bird allowed him to pass his hand frequently down its back, without muving or showing any fear. But if he offered to touch the eggs, the poor bird immediately pecked his hand."

Partridges, as a delicious article of food, have 
always been held in high esteem by the lovers of good fare. We have an old distich in its praise :-

"If the partridge had the woodcock's thigh, "T would be the best bird that ever did fly."

Mr. Mudie observes that partridges bred in the northern parts of the country, and which are called " hill partridges," are, though smaller, superior in flavour to the more bulky ones obtained on the rich lands: "It seems;" he says, "to be a law of nature, to which there are few exceptions, that the smaller any production runs, it is, if equally perfect, always the more delicate. Hill mutton, hill grain, and hill vegetables are so many proofs, and hill partridges are another." This author gives some very wise and suitable advice to the sportsman; he says: "When the birds of the season have come to maturity, they are far more than the winter could support. Many would, in consequence, die of starvation; therefore, while they are in season, go by all means to the field, inhale the bracing air of autumn, to fortify you against the cold of winter, and fire away. . . . But be a wise sportsman, and do not exterminate. Be an honest one, and 'bide your time.' From the time that the coveys pack, and you can with difficulty get within shot of 
them, to that when the next brood are on the wing, the birds are doing you nothing but good; and you can do them only harm. Man may not observe you, and you may evade the punishment of the laws; but do not on that account both injure and degrade yourself. Take your use, with knowledge, but be not an ignorant or wanton plunderer of that store, over which, for the greatest good of all, the eye of Omniscience keeps watch."

The RED-LEGGED PARTRIDGE is a native of France, Italy, and the islands of Guernsey and Jersey, from whence it has been imported into England and naturalized in some parts of the country. It is very common in Suffolk, and increasingly so in Norfolk, and is occasionally found in other countries. Mr. Knox says the introduction of these lirds into this country is a subject of regret with most sportsmen, owing, first, to their extreme shyness, the rapidity with which they run, and their reluctance to take wing; thus spoiling the dogs, as well as disappointing the shooter; and then, when killed, their flesh is far inferior to that of the other kind. Lastly, it has beeri found, in those districts where they have obtained a firm footing, the partial disappearance of our common partridge, has been the result,-one which is every way to be regretted. 
SCRAPERS; OR, POULTRY TRIBE.

\section{CHAPTER V.}

The Common Quail-Habits of this bird in England-The Israelites fed with Quails-Immense flight of Quails in Egypt-The Word of God and Natural History in perfect accordance - The Great Bustard - The largest of the Gallinaceous Family - Extirpated from the plains of England where it was formerly found-The pouch of the Bustard-An inhabitant of the plain countries of Europe -Extract of a letter from the "Camp before Sebastopol."

The common QUAIL is the smallest British bird of the poultry tribe, and is very like a partridge, except in size; and it also resembles that bird in many of its habits. It is a summer visitor in most parts of England; and in Ireland it has also been frequently found in the winter months, as well as occasionally in England also. It chiefly frequents corn-fields; but is now much more rarely seen than formerly. Quails run with great rapidity, and they also fly quick, but, generally, straight and low, and are difficult to "flush," sitting squat and sleeping at midday. Their long flights are understood to be performed in the night.

The London market is well supplied with quantities of these birds, which are netted on the 
continent, chiefly in France, and brought alive to this country in the spring, where they are subsequently fatted for the table. Their flesh is delicate, and it is, accordingly, very much in request; and in London, particularly during the season, the consumption is large.

There seems to be good reason for believing that this-the only migratory species of quail-is the identical bird alluded to by the psalmist, when it pleased the Almighty to furnish an ample supply of food to the famishing Israelites, in the wilderness, Psa. Ixxviii. 26-29, "He caused an east wind to blow in the heaven: and by his power he brought in the south wind. He rained flesh also upon them as dust, and feathered fowls like as the sand of the sea : and he let it fall in the midst of their camp, round about their habitations. So they did eat, and were well filled: for he gave them their own desire."

The history of this miraculous interposition, as given in the eleventh chapter of Numbers, is deeply interesting and instructive; and the accounts given by modern travellers fully corroborate the Scriptural details as to the prodigious numbers of quails, and the mode of drying them for food. In Stade's "Travels in Turkey," we read-“ Near Constantinople, in autumn, the sun is often almost obscured by the prodigious flights of quails, which 
alight on the coasts of the Black Sea, near the Bosphorus, and are caught by means of nets spread on high poles, against which the birds, exhausted by their passage over the sea, strike themselves, and fall."

Madden mentions that they visit Egypt in immense flights about harvest time, when the Arabs take them, by thousands, in nets. A French author says, that in a small island off the coast of Egypt, these birds usually alight in autumn, and are taken in immense quantities; and after being stripped of their feathers are dried in the hot sands, for about a quarter of an hour, and then sold for a penny a pound. The object of the Israelites, in spreading them round the camp, was, therefore, to dry them. Thus, observes Mr. Yarrell, "we see the most ancient and venerable of all histories, the word of God, and natural history, in perfect accordance; and we also learn how abiding and enduring are the works of the Lord. Here, through 3300 years, we find the perpetuation of an instinct, accompanied by a peculiarity, which is still observed, - that of these migratory flights being made by night. 'And it came to pass, that at even the quails came up, and covered the camp.',

The quail was honoured by the Phoenicians as having saved Hercules; a myth which may pro- 
bably be traced to the miraculuus support in the desert of the Israelites, the powerful neighbours of 'Tyre.

The GReat bustard, the last in Great Britain of the Gallinaceous Order, is by far the largest of the family. It is really a splendid bird; the male, when full grown, is four feet in length, and in breadth, nine feet. It was once not uncommon in this country, but is now so extremely rare that every individual capture is recorded. Its latest haunts were in the county of Norfolk; but even there it is now all but extinct. In olden times it was recorded that, " the bustard, as big as a turkey, was usually taken by greyhounds, on Newmarket heath." Salisbury Plain was also, formerly, one of its favourite localities. The last observed there was in 1813.

This bird combines so many characters that it stands alone, being different from every other genus. Independently of its size, and the quality of its flesh, which is highly prized, it is very interesting. The structure of the feet adapts it only to firm land; and, as it cannot perch, and is not well-formed for making its way among bushes, it is never found but in the open country. The bustard never wades, and seldom drinks. Its most powerful motion is, not running, but flight; for which, heavy as it is, its large wings well adapt it. 
The male is said to possess a capacious pouch, situate along the fore-part of the neck, and capable of holding several pints of water. Naturalists have been much puzzled to make out the use of this receptacle, and recently attention has been afresh directed to the subject. In "The Zoologist, for 1853 " (p. 4015), there is a paper, by Mr. Yarrell, on the habits and structure of this bird, containing many interesting particulars relating to it, and concluding with an account of an anatomical examination of the neck; but no pouch could be found, and Professor Owen, and Mr. Yarrell seem disposed to doubt the accuracy of former writers on this point, the latter acknowledging his opinion to be changed since the publication of his "British Birds." It should seem that the accounts formerly given of this bird were very incorrect, and now that it is become so rare, it is no easy matter to correct mistakes, and to supply necessary information. Well may we deplore the disappearance of the fine cock of the woods from the forests of Scotland, and almost equally so the extirpation of the great bustard from the plains of England.

The bustard is found in many parts of France and Italy, and in Spain and Portugal. It is also a native of Russia and the plains of Tartary. It is naturally a very wild bird, and in Germany, 
where it is very numerous, the sportsmen find it is so difficult to approach that they use as many devices to get within rifle-shot of it as are employed by the Highlanders when stalking red-deer. In Holland it is a rare bird. It may interest the reader to close this account of the bustard with an extract of a letter from our "Camp before Sebastopol," dated Dec. 21st, 1855.

"Winter is now come upon us in reality, and we have had, of late, some very cold weather; on the night of the 18th the thermometer went down to eight degrees below zero. . . . For the last few days we have had immense flocks of bustards flying from the eastward. Hundreds of sportsmen have been on the look-out for them, and several have been killed. They are very large. Some of those killed, I am told, weigh as much as fifteen or sixteen pounds. There is also snipe and wild fowl shooting to be had on the Tchernaya; but it is at the risk of one's life this sport is to be enjoyed, as the Russians are within shot, and generally take advantage of it." 


\section{IN DEX.}

Anecdote of a collection of trained gold-finches, linnets, and canaries, 187

Angora cat, the, and robin, 147

Argus pheasant, the, 251

Barn, the, or white owl, 89

Bee-eater, the, 228

Birds of prey, 47-95

Birds, habits, etc. of-parental love, 15 ; fear, 16 ; sympathy and fellow-feeling, 18; joy and playfulness, 20 ; emulation, 21 ; vanity and self-love, 23; sagacity, 24; language, communication, 28; social impulse, 33 ; confidence in man, 40

Bird's nest, a, Pennant's lines on, 142

Black-cap warbler, 157

Blackheaded bunting, the, 177

Black grouse, 255

Blue tit, the, 168

Bulfinch, 189; amusing note on its destructiveness, 190

Bunting, the common, 176

Buntings, the, 174, et seq.

Bustard, the great, 274

Butcher birds, 96, et seq.

Buzzard, the, 80

Capercailzie, the, or cock of the wood, 253

Carrier pigeon, 241; instances of power of speed in, 242
Carrion crow, 115

Cat, a, and a kestrel, curious tale of, 75

Chaffinch, the, 181

Chats, the, 164, et seq.

Chiff-chaff, the, 159

Chimney swallow, the, 208.

Chough, the, 124

Climbing birds, the, 216, et seq.

Cockney sparrow and the keeper of an early breakfast-stall, 197

Conical beaked perchers, 172, et seq.

Crow, the, 114, et seq.

Crows, the, 111, et seq.

Cuckoo, the, 224

Dipper, the, 106

Domestic pigeons, 241

Doves, 232, et seq.

Duck, the, its origin, 9

Eagle, the, 48, et seq.; British species, 55 ; Job's poetical description of, 64

Falcon tribe, the, 48 , et seq.

Falconry, 71, et seq.

Falcons, the true, 70 , et seq.

Fallow chat, the, 165

Fieldfare, the, 105

Finches, the, 180, et seq.

Firecrested wren, the, 149

Fishing-hawk, the, 67 
Flight, modes of, in birds of prey, 53

Flycatchers, 100, et seq.

Fowl, the domestic, its origin, 6

Gallinacenus birds, 232-276

Garden thrush, the, 103

Garden warbler, the, 159

Geese, domestic, origin of, 9

"Gléd," or "Glead," the, 79

Goatsucker, the, 213

Golden-crested wren, 149

Golden eagle, the, 55

Golden pheasant, the, 251

Goldfinch, the, 186

Gold-vented thrush, the, 108

Goshawk, the, 76

Great shrike, the, 99

Great tit, the, 167

Greenfinch, the, 185

Green woodpecker, the, 219

Grosbeak, the common, 185

Grouse, 253, et seq.

Guinea fowl, the common, 8

Gyr, the, or Iceland falcon, 70

Halcyon, the, 229

Harriers, the, 81, et seq.

Hawfinch, the, 185

Hawking, 72, et seq.

Hawks, the, 76, et seq.

Hedge-warbler, the, 160

Hedge sparrow, the, 160

Hen-harrier, the, 82

Heron, the, 71

Hobby, the, 74

Hooded, the, or Royston crow, 122

Hoopoe, the, 228

House martins, 211

House sparrow, the, 195

Iseland falcon, the, 70
Impey pheasant, the, 252

Insessores, 96-231

Introductory chapter, $13-45$

Ivy, or tawny owl, 94

Jackdaw, the, 126 ; curious account of, 127

Jay, the, 129

Kestrel, the, 74; curious tale of a cat and $\mathrm{a}, 75$

Kingfisher, the, 229

Kite, the, 79

Larks, the, 172, et seq.

Linnets, the, 182, et seq.

Long-tailed tit, the, 168

Magpie, the, 131; superstitions res* pecting 132; anecdotes of tame, 133

Marsh harrier, the, 81

Martin, the, 208; touching instance of parental affection in, 211

Meadow pipit, the, 162

Mealy redpole, the, 185

Merlin, the, 74

Migratory birds, some, dates of their appearance and departure, 206

Missel thrush, the, 102

Montagu's harrier, 83

Moorfowl, the, 257

Mountain linnet, the, 184

Nightingale, the, 149; Walton on the, 151

Night jar, the, 213

Nut-hatch, the, 221

Osprey, the, 67 
Owls, 84; et seq; entertaining account of a colony of, 90 ; Scriptural references to the owl, 94

Parrots, 230; curious anecdote of, 231

Passenger pigeon, 240

Partridge, the common, 262, et seq. Peacocks, 8

Perching birds, 96-231

Peregrine falcon, 70

Pettychaps, the, 159

Pheasant, the, 246, et seq.

Pied flycatcher, the, 102

Pied wagtail, the, 144

Pies, the, 111, et seq.

Pigeons, 232, et seq.

Pink, the, 181

Pintado, the, 8

Pipits, the, 162, et seq.

Poultry tribe, the, 232-276

Preface, 5-12

Ptarmigan, the, 259

Quail, the common, 271; Scripture references to, 272

Rapacious birds, $47-95$

Raptores, 47-95

Rasores, 232-276

Raven, the, 111; anecdote of a tame, 113

Red-backed shrike, the, 100

Redbreast, the, 145

Red grouse, the, 257

Red-legged crow, the, 124

Red-legged partriàge, the, 270

Redpole, the greater, 182

Redpole, the lesser, 183

Redstart, the, 155

Redwing, the, 105

Reed bunting, the, 177

Reed warbler, the, 155
Ring-dove, the, 236

Ringed pheasant, the, 251

Ring ousel, the, 108

Robin, the, 145; and Angora cat, 147

Rock dove, the, 237

Rock pipit, the, 163

Rock thrush, the, 108

Rook, the, 114, et seq.; remarkable instance of a rook's attachment for man, 119

Rooks, are they useful or injurious to the husbandman? 116

Rose-coloured pastor, the, 136

Royston crow, the, 122

Sand martin, the, 207

Scrapers, the, 232-276

Sea, the, or white-tailed eagle, 62

Sedge-warbler, the, 155

Shrikes, the, 96 , et seq.

Silver pheasant, the, 251

Skua gulls, chase of a sea-eagle by, 63

Sky-lark, the, 172

Snow-bunting, the, 178; nest ofaffecting anecdote by Captain Lyon, 178

Snowflake, the, 178

Snowy owl, the, 88

Song, or garden thrush, the, 103; anecdote of, 104

Sparrow hawk, the, 77; anecdotes of, 77

Sparrows, 181, 195, et seq.; our Lord's allusion to, 199

Sparrows, London, impudence of, 197

Spotted eagle, the, 55

Spotted flycatcher, the, 100 ; anecdotes of, 101

Starling, the, 134

Stockdove, the, 237 
Stonechat, the, 164; Mudie's description of, 164

Swallow, the, 141; the ancients and, 209

Swallows, the, 200, et seq.

Swift, the, 208212 ,

Sylvan warblers, the, 155

Tawny owl, the, 94

Thrush tribe, the, 102, et seq.

Titmouse, the long-tailed, 141; anecdote of a tame, 171

Tits, the, 167 , et seq.

Tom-tit, the, 167

Tree creeper, the, 221

Tree pipit, the, 163

Tree sparrow, the, 195

Turkey, the, its origin, etc., 7

Turtle-dove, the, 239

Twite, the, 184

Vulture, solitary, seen in England 47

Wagtails, the, 143, et seq.

Warblers, the, 137, et seq.; the true, 152 , et seq.
Water ousel, the, 106

Water wagtail, a, curious anecdote of, 145

Wheatear, the, 165

Whin chat, the, 165

White grouse, the, 259

White owl, the, 89

White-tailed eagle, the, 63

Whitethroat, the common, 156; and nightingale, anecdote of, 157

White's thrush, 108

Willow warbler, the, 161

Windhover, the, 75

Woodchat shrike, the, 99

Woodpeckers, the, 216

Wood owl, the, 94

Wood warbler, the, 160

Word of God, the, and natural his. tory, 273

Wren, the common, 148

Wrens, the, 145 , et seq.

Wryneck, the, 220

Yellow bunting, the, $\mathbf{1 7 1}$

Yellow hammer, the, 174

Yellow wagtail, the, 144 


\section{IIST OF ENGRAVINGS.}

Bee-eater, the, 227

Bulfinch, the, 201

Buzzard, the, 66

Creeper, the common, 217

Cuckoo, the, 227

Gold Crest, the, 153

Golden Eagle, the, Frontispiece

Goldfinch, the, 169

Great Bustard, the, 263

Green Woodpecker, the, 217

Hoopoe, the, 227

Jay, the, 110

Kingfisher, the, 227

Kite, the, 66

Long-eared Owl, the, 86

Martin, the, 201

Meadow Pipit, the, 153

Missel Thrush, the, 97

Nightingale, the, 139

Night-jar, the, 201

Nut-hatch, the, 217
Partridge, the, 263

Peregrine Falcon, the, 66

Pied Wagtail, the, 139

Quail, the, 263

Raven, the, 110

Red-backed Shrike, the, 97

Redbreast, the, 153

Reed Wren, the, 139

Rose-coloured Pastor, the, 110

Sky-lark, the, 169

Snowy Owl, the, 86

Sparrow-hawk, the, 66

Spotted flycatcher, the, $\mathbf{9 7}$

Starling, the, 110

Swift, the, 201

Tawny Owl, the, 86

Tom-tit, the, 169

Water Ousel, the, 97

Wheatear, the, 153

Wren, the, 139

Wryneck, the, 217

Yellow-hammer, the, 169 
LONUON :

PRINTED BY W. CLOWES AND SONS, STAMHORD STREET, AND CHARING CRUSS. 


\section{PUBLICA'TIONS}

OF THE

\section{RELIGIOUS TRACT SOCIETY.}

Natura1 History, Science, and Phenomena.

\section{BIRDS;}

An Introduction to the Study of Brrds, on Scientific

Principles.

Royal 18mo. Superior Engravings. 7s, extra cloth boards.

QUADRUPEDS;

A Popular Introduction to the Study of Quadrupeds, on Scientific Principles.

Royal 18mo. Superior Engravings. 6s. extra cloth boards;

8s. half-bound.

\section{REPTILES;}

A Popular History of Reptilles; or, An Introduction to the Study of the Class Reptilia, on Scientific Principles.

Royal 18mo. Superior Engravings. 6s. extra cloth boards;

8s. half-bound.

\section{BRITISH QUADRUPEDS;}

16mo. Embellished with fine Engravings on Wood. 3s. $6 d$. elegantiy bound in cloth, gilt edges; $4 s$. $6 d$. coloured plates.

\section{SCRIPTURE NATURAL HISTORY;}

Royal 18mo. Numerous Engravings. 2s. 6d. cloth boards; 3s. elegant.

\section{BIRDS;}

Containing "The Nest," "The Egg," "The Feather," "The Song-Bird," "Instinct of Birds."

Engravings. 1s. 6d. cloth.

\section{HISTORY OF INSECTS;}

$16 \mathrm{mo}$ square. Illustrated with superior Engravings. 3s, elegantly bound in cloth, gilt edges.

REMARKABLE INSECTS;

Containing “The Honey Bee," "The Fly," "The Ant,"

"The Spidfr," "The Gall Insect."

Engravings. $1 s .6 d$, cloth.

HIVE AND ITS WONDERS;

19mo. Engravings. $1 s$. cloth boards; $1 s, 6 d$. extra boards, gilt edges 


\section{PUBLICATIONS OF THE}

THE WATERS OF THE EARTH ;

Coutaining “The Dewdrup," “The Spring," "The Lake," "The Rrver," and "The Sea," which are published separately.

With engraved Frontispiece, $16 \mathrm{mo}$ square. $1 s .6 d$. cloth boards, gilt edges.

WONDERS OF THE WATERS; Containing "The Animalcule," “The Coral-Maker," "The Sea-Star," "The Lobster," "The Fish." $16 \mathrm{mo}$ square. Engravings. 1s. $6 d$. cloth boards.

SHELLS AND THEIR IN MATES. $16 \mathrm{mo}$ square, with Engravings. $3 s .6 d$. cloth boards.

'THE FACE OF THE EARTH; Containing "The Mountarn," "The Valley," "ThF Prairie," "The Island," and "The Desert." With Embellishments. $16 \mathrm{mo}$ square, cloth elegant, 1s.6d.

PI,ANTS;

Containing "The Seed," "The Leaf," "The Flower," "The Fruit," The Grass."

$16 \mathrm{mo}$ square, with Engravings. $1 s .6 d$. cloth boards.

CURIOSITIES OF ANIMAL LIFE;

With the Recent Discoveries of the Microscope.

Foolscap 8vo. With Engravings. 2s, cloth boards.

PHILOSOPHY OF FOOD AND NUTRITION;

By the Rev. F. Sidney.

Foolscap 8 vo. 2s. cloth boards; $2 s .6 d$. gilt edges,

THE SENSES;

Containing "The Exe," "The Tongue," "The Hand," "The Ear," "The Sense of Syell."

$16 \mathrm{mo}$ square, with Engravings. 1s, $6 d$. cloth boards.

ELECTRICITY;

Its Phenomena, Laws, and Results.

16mo square, with Engravings. 3s. cloth boards.

HEAT ;

Its Sources, Influence, and Results.

16mo square, with Engravings. 3s. cloth boards.

NATURE'S WONDERS;

Or, God's Care Over all his Works. 18mo. Engravings. 2s, cloth boards. 


\section{RELIGIOUS TRACT SOCIETY.}

NECESSITY AND CONTRIVANCE;

Or, Food, Clothing, and Shelter.

18mo. with Engravings. 2s, cloth boards.

PEEPS AT NATURE;

Or, Gov's Works and Man's Ways,

18mo. with Engravings. 1s. 6d. cloth boards.

VILLAGE SCIENCE;

Or, The Laws of Nature Explained.

18mo. Engravings. 2s, cloth boards.

WAYSIDE FRAGMENTS;

Or, Wonders in Common Things.

18mo. Engravings. 1s. $6 d$. cloth boards; $2 s$, extra boards, gilt edges.

THE TRAVELLER;

Ur, Descriptions of Various Wonders in Nature and ART.

18mo. Cloth boards, 1s. $6 d$; half-bound, $2 s$.

BOTANICAL LADDER FOR THE YOUNG. 18mo. Cloth boards, 1s. $6 d$; ; half-bound, $2 \delta$.

THE YOUNG BOTANISTS.

Frontispiece and Engravings, 18mo. 1s. cloth; 1s. $6 d$. extra boaräs.

The following are published at 6 d. paper covers; 10d.cloth boards gilt edges. $18 m o$, fine paper and print.

\section{Natural History.}

Garden Flowers of the Year.

Wild Flowers of the Year.

Our Song Birds.

Our Domestic Fowls.

Palm 'Tribes.

Plants and Trees of Scripture.

Comparisons of Structure in Animals.

British Fish and Fisheries.

The Geography of. Plants.

Science, etc.

The Solar System. By Dr. Dick Parts I. and II.
The Telescope and Microscope.

The Atmosphere. By Dr. Diak.

Agriculture.

Blights of the Wheat, and their Remedies. By the Rev. E. Sidney.

Ths Field and the Fold. By the Rev. E. Sidney.

\section{Natural Phenomena.}

The Senses and the Mind.

Voleanoes: their History, Phenomena, ete.

The Caves of the Earth.

Wonders of Organic Life.

Magic, Pretended Miracles, etc. 


\section{MISCELLANEOUS.}

HISTORICAL TALES FOIR YOUNG PRO. TESTAN'IS.

Royal 18mo. Fine Engravings. 2s. cloth boards; $2 s .6 d$. extra boards, gilt edges.

THE OTTOMAN EMPIRE;

The Sultans, the Territory and the People.

Royal 18mo. With a Map. $2 s .6 d$. cloth boards.

THE NEW BIBLICAL ATLAS, AND SCRIP. TURE GAZETTEER;

With Notices of the Tabernacle and the Temple. Containing Twelve superior MAPS and Plans, together with descriptive Letter-press of the Topography of the countries mentioned, carefully compiled from the latest authorities. Super-royal 8vo. 2s. $6 \alpha$. plain; outlines coloured, 4s.; on imperial drawing paper full coloured, and bound in boards, $6 s .6 \bar{d}$.

\section{THE LIFE OF AMELIA OPIE;}

By Miss Brightwell.

With Portrait. Foolscap 8vo. 3s. in cloth boards.

MEMOIR OF OLD HUMPHREY; With Gleanings from his Portrolio in Prose and Verge With Steel-plate Portrait. Twenty-fourth Thousand. 18mo. $2 s$. cloth boards.

FLOWERS FROM MANY LANDS; a Christian Companion for Hours of Recreation. In Prose and Verse.

With superior Engravings of Flowers in Oil Colours. 5s. elegantly bound, giit edges.

THE CHRISTIAN WREATH OF PROSE, POETRY, AND ART.

With eight coloured Engravings. Foolscap 8vo. 5s, extra boards, gilt edges.

THE CHRISTIAN GARLAND;

A Companion for Leisure Hours.

Coloured Engravings. Foolscap 8vo. 5s, extra boards, gilt edges.

THE ROSE BUD;

A Christian Gift to the Young.

Fine wood and coloured Engravings. Royal 16mo. 4s, extra boards, gilt edges. 

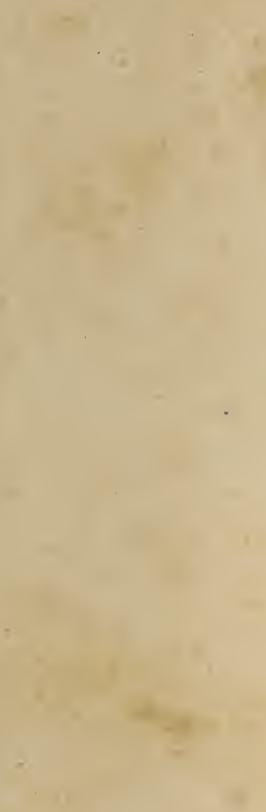

\section{(n)}





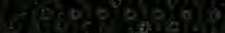

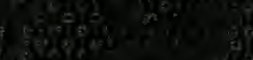

is

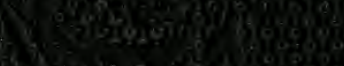

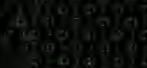

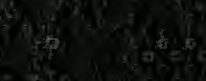

So $3 x$

yrising

sigho

s)

2.

in:

Q

in:

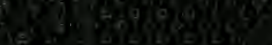

